\title{
Fluorescent Sensors for the Detection of Heavy Metal Ions in Aqueous Media
}

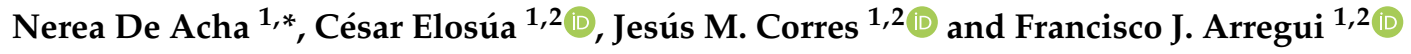 \\ 1 Department of Electric, Electronic and Communications Engineering, Public University of Navarra, E-31006 \\ Pamplona, Spain; cesar.elosua@unavarra.es (C.E.); jmcorres@unavarra.es (J.M.C.); \\ parregui@unavarra.es (F.J.A.) \\ 2 Institute of Smart Cities (ISC), Public University of Navarra, E-31006 Pamplona, Spain \\ * Correspondence: nerea.deacha@unavarra.es; Tel.: +34-948-166-044
}

Received: 21 December 2018; Accepted: 23 January 2019; Published: 31 January 2019

\begin{abstract}
Due to the risks that water contamination implies for human health and environmental protection, monitoring the quality of water is a major concern of the present era. Therefore, in recent years several efforts have been dedicated to the development of fast, sensitive, and selective sensors for the detection of heavy metal ions. In particular, fluorescent sensors have gained in popularity due to their interesting features, such as high specificity, sensitivity, and reversibility. Thus, this review is devoted to the recent advances in fluorescent sensors for the monitoring of these contaminants, and special focus is placed on those devices based on fluorescent aptasensors, quantum dots, and organic dyes.
\end{abstract}

Keywords: heavy metal ions; fluorescent sensors; fluorescent aptasensors; quantum dots; organic dyes

\section{Introduction}

Monitoring the presence of contaminants in water is of general interest in order to ensure the quality of surface, ground, and drinking water [1,2]. Among the several water pollutants, such as plastic or waste [3], chemical fertilizers or pesticides [4], and pathogens [5], heavy metal ions are known for their high toxicity [6]. Although some of them are essential nutrients (for instance, iron, zinc, or cobalt), they can be toxic at higher concentrations [7]. For their part, cadmium, lead, and mercury are highly poisonous even at trace levels [8,9], showing a close association to cancer or neurodegenerative diseases $[10,11]$. Furthermore, heavy metal ions are non-biodegradable substances [12] and they have an accumulative effect in human body [13], where they enter, typically, through the air [14], beverages [15], and the food chain [16], in which water plays a key role. There, metal ions can be found as a result of vehicle emissions [17], batteries [18], or industrial activities [19]. Thus, their detection at low concentrations is a matter of priority for environmental protection and disease prevention as well [20].

This issue requires highly sensitive and selective devices [21,22], which can be based on different technologies; for instance, electronics [23], electrochemistry [24], or optics [25]. In particular, optical sensors present numerous attractive features: the ease of integration in microfluidic platforms [26] and the capability of monitoring hazardous environments [27] are just two of them. Among the optical sensors, fluorescent ones have gained popularity in recent years since they provide high specificity as well as low detection limits, fast response time, and technical simplicity $[28,29]$. Their working principle consists of the emission of light by a material (fluorophore) after being excited at lower wavelengths [30]. The intensity (or lifetime) of that emission varies with the concentration of the target analyte [31]. So far, several materials, such as porphyrins [32], metal-organic frameworks [33], DNAzymes [34], fluorescent 
aptamers [35], quantum dots [36], or organic dyes [37] have been developed for the monitoring of heavy metal ions in water. This review is focused on the recent advances in sensors that employ the last three kinds of materials: the first section is devoted to the different techniques based on fluorescent aptamers, the second one is dedicated to the sensors fabricated with quantum dots and, finally, the third one analyzes the devices developed using organic dyes.

\section{Heavy Metal Ion Sensors Based on Fluorescent Aptamers}

Aptamers are a type of artificial oligonucleotide $(\mathrm{ON})$ sequences with the ability of specifically binding to a target molecule [38]. Among their several attractive properties for the design of sensors are good thermal stability [39], the ease of synthesis and modification [40], or their simple immobilization procedure [41]. Their high affinity and specificity toward each of their target analytes [42,43] is the most remarkable property. Consequently, aptamer-based detection techniques have emerged as very selective recognition tools [44-46].

For instance, thymine (T) exhibits great affinity towards mercury (II) ions, forming $\mathrm{T}-\mathrm{Hg}^{2+}-\mathrm{T}$ base pairs in DNA duplexes [47], and cytosine (C) forms $\mathrm{C}-\mathrm{Ag}^{+}-\mathrm{C}$ mismatches when it interacts with $\mathrm{Ag}^{+}$ions [48]. Thus, since the first $\mathrm{ON}-$ based $\mathrm{Hg}^{2+}$ sensor was reported by Ono et al. [49], T-rich ON sequences have been widely employed for the selective detection of $\mathrm{Hg}^{2+}$ in water samples [50-52]. Furthermore, several selective sensors for $\mathrm{Ag}^{+}$have also been reported in the literature [53-55]. The basis of $\mathrm{Hg}^{2+}$ sensors based on aptamers is the conformational change of the T-rich ON sequence, which acquires a hairpin structure due to $\mathrm{T}-\mathrm{Hg}^{2+}-\mathrm{T}$ mismatches, as shown in Figure $1 . \mathrm{As}^{+} \mathrm{Ag}^{+}$ions and cytosine form $\mathrm{C}-\mathrm{Ag}^{+}-\mathrm{C}$ base pairs, $\mathrm{Ag}^{+}$monitoring is carried out with similar sequences than $\mathrm{Hg}^{2+}$, but substituting the thymine groups with cytosine ones.

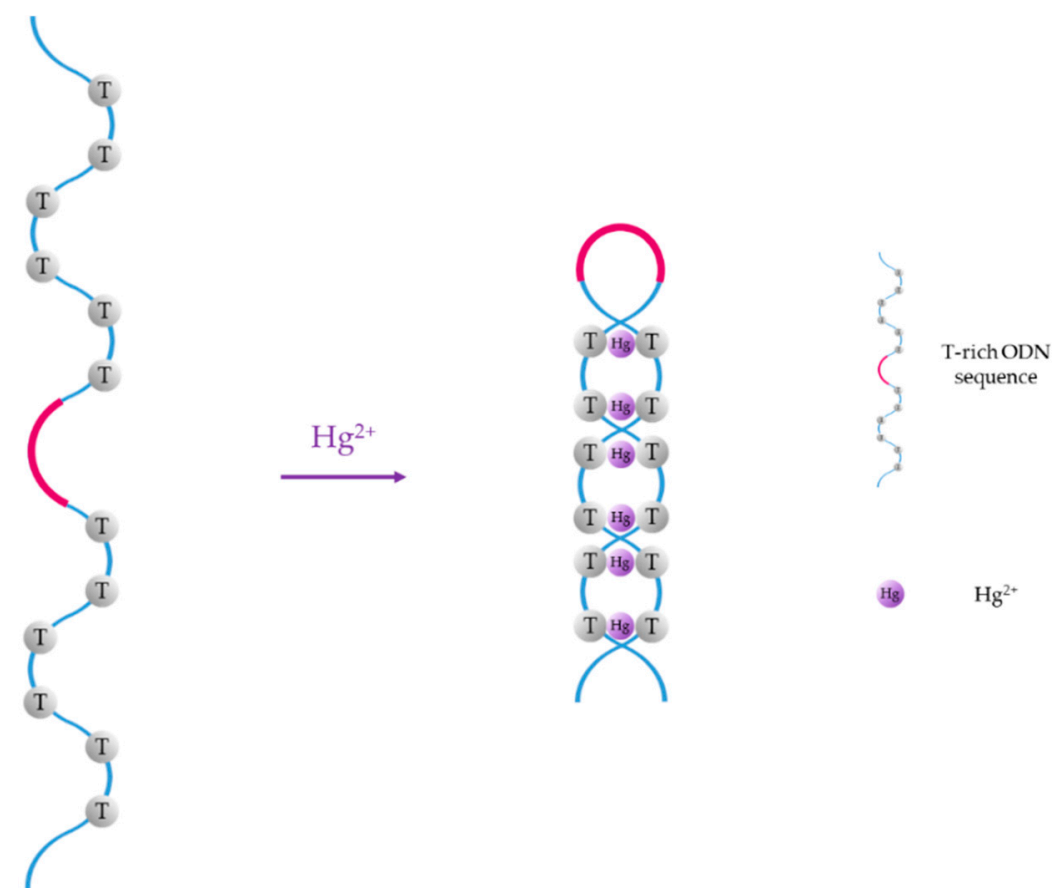

Figure 1. $\mathrm{Hg}^{2+}$-induced formation of $\mathrm{T}-\mathrm{Hg}^{2+}-\mathrm{T}$ mismatches.

Another particular case is the formation of guanine $(\mathrm{G})$-quadruplexes induced by the presence of $\mathrm{Pb}^{2+}[56]$, as it is depicted in Figure 2. Although other metal ions, such as $\mathrm{K}^{+}, \mathrm{Na}^{+}$, or $\mathrm{Ca}^{2+}$ can slightly influence the conformation of the G-quadruplex structure [57], G-rich aptamers show good selectivity and specificity towards $\mathrm{Pb}^{2+}$ [58] owing to the high binding ability between $\mathrm{Pb}^{2+}$ and $\mathrm{G}$ bases [59]. 


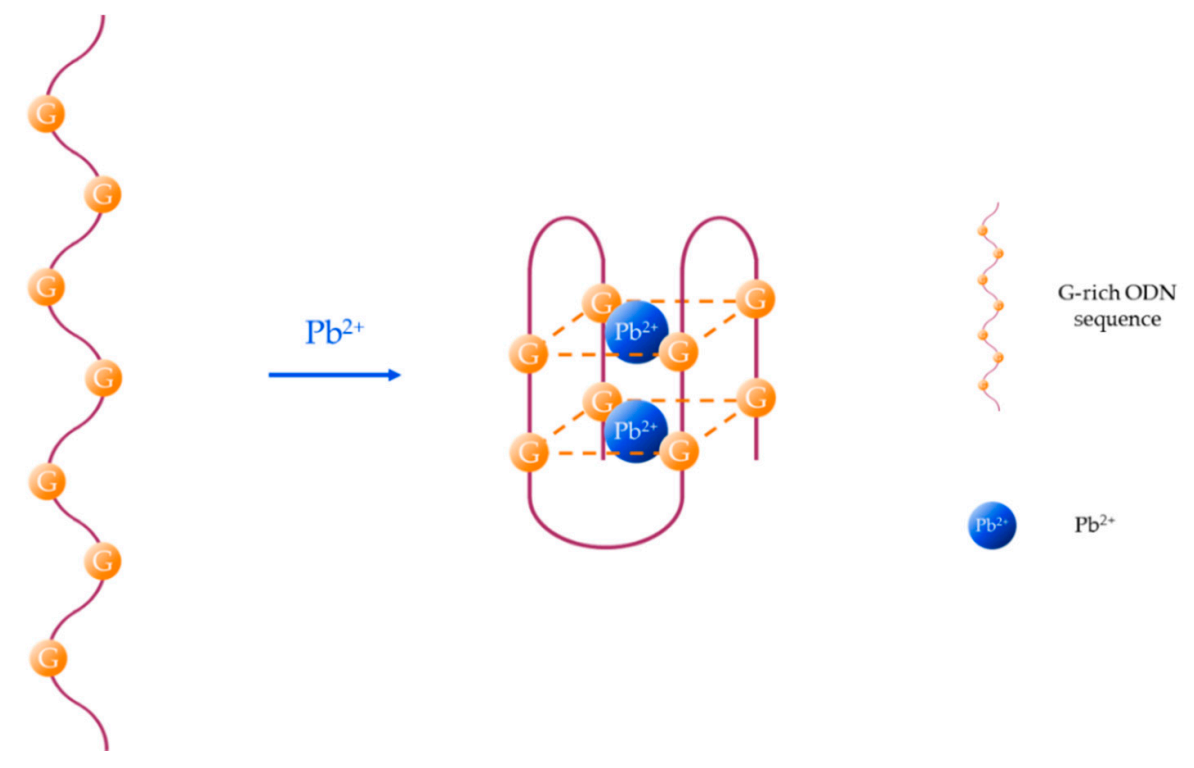

Figure 2. $\mathrm{Pb}^{2+}$-induced formation of G-quadruplex structures.

Utilizing these sensing structures, different fluorescent detection strategies have been developed, all of them determined by the conformational change of the ON sequences in the presence of the target metal ion.

The main mechanisms for the monitoring of heavy metal ions with aptamers are shown in Figure 3. For the sake of simplicity, the sensing procedures exposed in this schematic are specific for the particular case of $\mathrm{Hg}^{2+}$, but they can be implemented for the detection of other metal ions as long as these compounds induce a conformational change of the aptamer. These detection procedures, as well as the labelling of the fluorophores (and, if necessary, the quenchers), depend on the utilization of one or two DNA strands, as explained below.

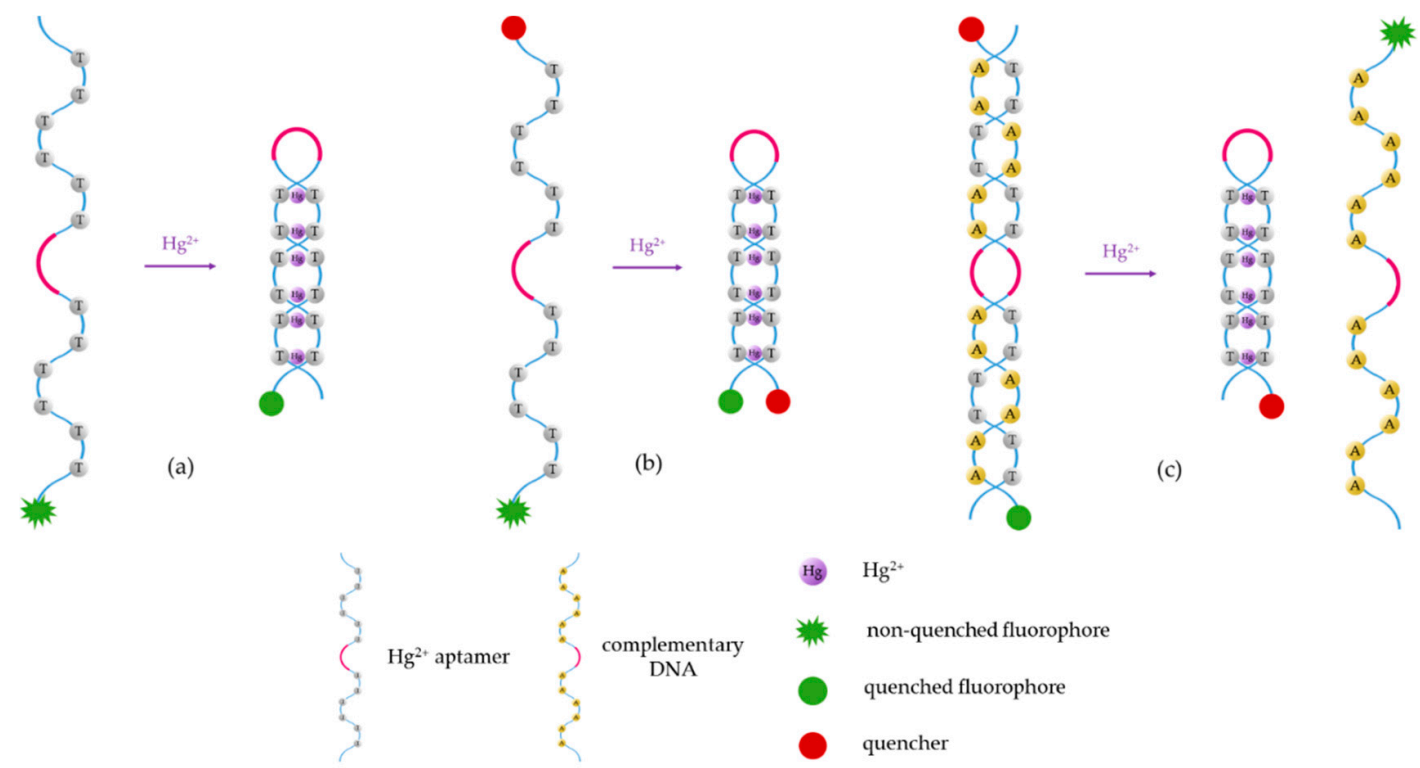

Figure 3. Schematic of the different $\mathrm{Hg}^{2+}$ sensing procedures utilizing fluorescent aptasensors: (a) the fluorophore is labeled to the sensitive aptamer, $(\mathbf{b})$ the fluorophore and the quencher are linked to the two terminis of the aptamer, and (c) the fluorophore and the quencher are labeled to the aptamer and the complementary DNA, or vice versa. These sensing procedures can be applied to detect other heavy metal ions just by substituting the T-rich sequences by the appropriate ON sequence. 
In the case of utilizing a single T-rich ON sequence, the luminophore is usually labeled to one of its termini $\left(5^{\prime}\right.$ or $\left.3^{\prime}\right)$. Its fluorescent emission can be quenched either by the electron transfer to the $\mathrm{T}-\mathrm{Hg}^{2+}-\mathrm{T}$ mismatches (Figure 3a) [60] or by a quencher linked to the other termini $\left(3^{\prime}\right.$ or $\left.5^{\prime}\right)$ of the sensitive strand (Figure 3b) [61]: as the $\mathrm{T}_{-} \mathrm{Hg}^{2+}-\mathrm{T}$ mismatches are formed, the ON sequence acquires a hairpin structure [62], decreasing the distance between the fluorophore and the quencher. This fact promotes the energy transfer between the first one (which acts as donor) and the second one (which acts as acceptor) [63].

The third procedure (Figure 3c) consists of the detection of $\mathrm{Hg}^{2+}$ by competitive binding: a T-rich aptamer (labeled to the fluorophore or the quencher) is usually linked to its complementary DNA (labeled to the quencher or the fluorophore). In the presence of $\mathrm{Hg}^{2+}$, the complementary DNA separates from the aptamer, to which the $\mathrm{Hg}^{2+}$ ions bind, forming the $\mathrm{T}-\mathrm{Hg}^{2+}-\mathrm{T}$ mismatches that give rise the hairpin structure [64].

Typical fluorophores that are labeled to the sensitive DNA sequences are dyes, such as 6-carboxyfluorescein, (6-FAM), carboxytetramethylrhodamine (TAMRA), or Texas Red, among others, as well as fluorescent quantum dots and up-conversion nanoparticles. Chen et al. [65] developed a mercury-mediated aptamer-beacon by labeling a 6-carboxyfluorescein (FAM) to the $5^{\prime}$ termini of a T-rich oligonucleotide: 5'-FAM-CGC TTG TTT GTT CGC ACC CGT TCT TTC TT-3'. In the presence of $\mathrm{Hg}^{2+}$, this aptamer acquired a hairpin structure due to the formation of the $\mathrm{T}-\mathrm{Hg}^{2+}-\mathrm{T}$ pairs. This led to the fluorescence resonance energy transfer (FRET) from the FAM to the T- $\mathrm{Hg}^{2+}-\mathrm{T}$ base pairs and, consequently, to the decrease of the fluorescence intensity, as displayed in Figure 4. The sensing system exhibited a limit of detection (LOD) of $4.28 \mathrm{nM} \mathrm{Hg}^{2+}$ and a linear detection range from $14.2 \mathrm{nM}$ to $300 \mathrm{nM} \mathrm{Hg}^{2+}$. Furthermore, the selectivity of the sensor for $\mathrm{Hg}^{2+}$ over a series of metal ions $\left(\mathrm{Pb}^{2+}\right.$, $\mathrm{Ag}^{+}, \mathrm{Cu}^{2+}, \mathrm{Ca}^{2+}, \mathrm{Ba}^{2+}, \mathrm{Ni}^{2+}, \mathrm{K}^{+}, \mathrm{Cd}^{2+}, \mathrm{Co}^{2+}, \mathrm{Cr}^{3+}, \mathrm{Fe}^{3+}, \mathrm{Al}^{3+}, \mathrm{Mn}^{2+}$, and $\mathrm{Zn}^{2+}$ ) was also analyzed: it was found that not one of them presented any kind of interference, even at 16-67 times higher concentrations than that of $\mathrm{Hg}^{2+}$.

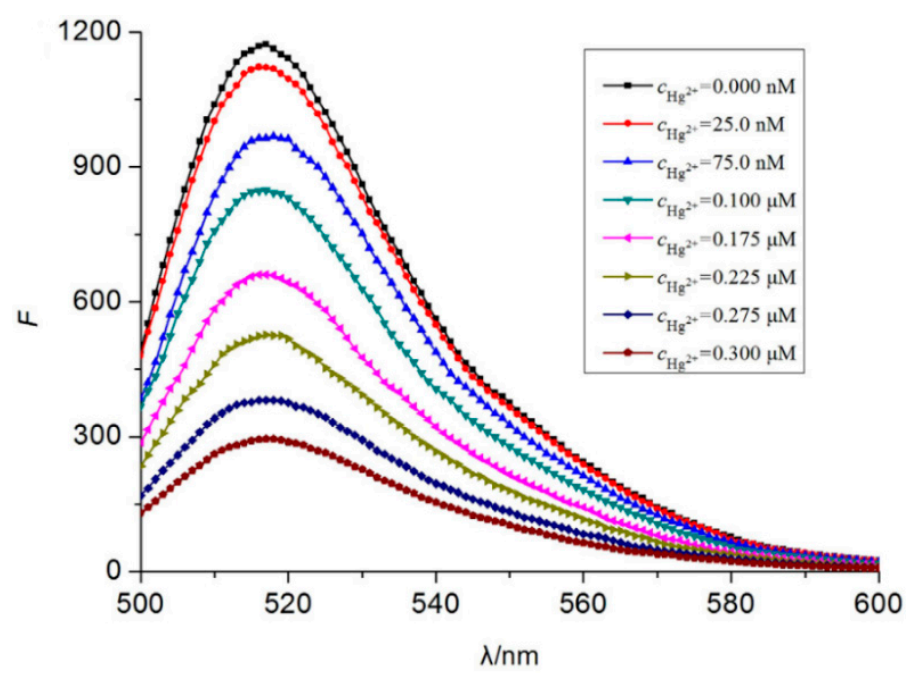

Figure 4. Fluorescence spectra of 5'-FAM-CGC TTG TTT GTT CGC ACC CGT TCT TTC TT-3' for different $\mathrm{Hg}^{2+}$ concentrations. Reprinted with permission from [65].

As explained previously, the fluorescent emission of the dyes can also be attenuated by a quencher linked to the opposite termini of the sensitive aptamer. One which has been widely employed with this aim is 4-([4-(dimethylamino)phenyl]azo)benzoic acid (DABCYL) [66], owing to its broad absorption spectrum [67]: the sensor reported by Li and co-authors [68] presented a linear calibration curve between $10 \mathrm{nM}$ and $200 \mathrm{nM}$, with a LOD of $10 \mathrm{nM} \mathrm{Hg}^{2+}$. Furthermore, in order to avoid the biodegradation of the aptamer, it was encapsulated in a porous phospholipid nanoshell (PPN), allowing its utilization in human urine samples. 
Additionally, by labeling FAM and DABCYL to the $5^{\prime}$ and $3^{\prime}$ terminus of a thrombin-binding aptamer (TBA), which is also a T-rich sequence, $\mathrm{a} \mathrm{Pb}^{2+}$ and $\mathrm{Hg}^{2+}$ sensor was developed: it presented a LOD of $300 \mathrm{pM}$ and $5 \mathrm{nM}$ for $\mathrm{Pb}^{2+}$ and $\mathrm{Hg}^{2+}$, respectively, and linear detection ranges from $0.5 \mathrm{nM}$ and $30 \mathrm{nM}$ for $\mathrm{Pb}^{2+}$ and from $10 \mathrm{nM}$ to $200 \mathrm{nM}$ for $\mathrm{Hg}^{2+}$ [61]. As the TBA is a T- and G-rich aptamer [69], in order to develop a sensor for a specific metal ion, masking agents were used: the presence of $\mathrm{Pb}^{2+}$, and that of $\mathrm{Cu}^{2+}, \mathrm{Co}^{2+}, \mathrm{Ni}^{2+}, \mathrm{Cd}^{2+}, \mathrm{Cr}^{3+}, \mathrm{Al}^{3+}$, and $\mathrm{Fe}^{3+}$ ions as well, was masked by adding phytic acid to the samples. The interference of $\mathrm{Hg}^{2+}$ was avoided by utilizing $\mathrm{CN}^{-}$and a random DNA, as can be seen in Figure 5. Regarding to the reutilization of the sensor, it provided recoveries between the $95 \%$ and the $104 \%$.

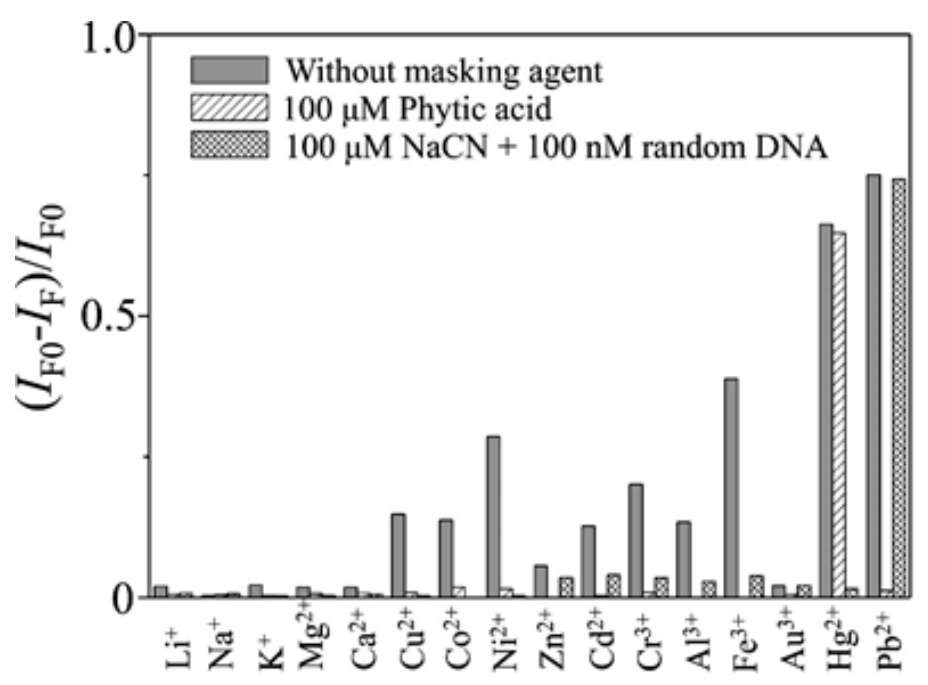

Figure 5. Quenching efficiency $\left(I_{\mathrm{F} 0}-I_{\mathrm{F}}\right) / I_{\mathrm{F} 0}$ of the fluorescence intensity $(518 \mathrm{~nm})$ of the TBA-based sensor in the presence of metal ions in the absence and presence of masking agents. Concentrations: $\mathrm{Hg}^{2+}, 1.0 \mu \mathrm{M} ; \mathrm{Pb}^{2+}, 100 \mathrm{nM} ; \mathrm{Li}^{+}$and $\mathrm{Na}^{+}, 100 \mu \mathrm{M} ; \mathrm{K}^{+}, \mathrm{Mg}^{2+}$, and $\mathrm{Ca}^{2+}, 10 \mu \mathrm{M}$; other ions, $1.0 \mu \mathrm{M}$. Reprinted with permission from [61]. Copyright 2009 American Chemical Society.

As gold nanoparticles (Au NPs) are good energy acceptors [70], they are another kind of fluorescence quenchers [71]: by covalently linking a $\mathrm{Hg}^{2+}$-sensitive aptamer labeled with FAM to an $\mathrm{Au} \mathrm{NP}$, it was possible to linearly monitor the $\mathrm{Hg}^{2+}$ concentration from $20 \mathrm{nM}$ to $1000 \mathrm{nM}$ [29], with a LOD of $16 \mathrm{nM}$. Furthermore, the utilization of Au NPs helped to stabilize the aptamer and decrease the LOD [72]. The quenching effect of Au NPs has also been utilized to fabricate "turn-on" fluorescent sensors: while the sensitive aptamer is linked to an Au NP (quencher), the complementary DNA sequence is labeled with a fluorophore [73], or vice versa [74]. In the absence of mercury (II) ions, the aptamer and the complementary strand are linked, so the fluorophore and the Au NP are in proximity and fluorescence transfer occurs, resulting in a negligible fluorescent emission. In the presence of $\mathrm{Hg}^{2+}$, due to the high specificity of the thymine groups to this metal ion, the sensitive aptamer acquires a hairpin structure, displacing the complementary strand away from the Au NP, which leads to an increase of the fluorescence [64].

Based on the competitive binding mechanism, an optical fiber sensor for monitoring $\mathrm{Pb}^{2+}$ was fabricated [75]. The complementary strand was deposited onto the optical fiber: in the absence of $\mathrm{Pb}^{2+}$, when the Cy5.5-labeled aptamer bound to the complementary DNA, its fluorescent emission was coupled to the optical fiber. Oppositely, when $\mathrm{Pb}^{2+}$ was present, it induced the aptamer to form G-quadruplex structures, being detached from the complementary strand, which resulted in a decrease of the coupled fluorescent intensity, as can be observed in Figure 6. 

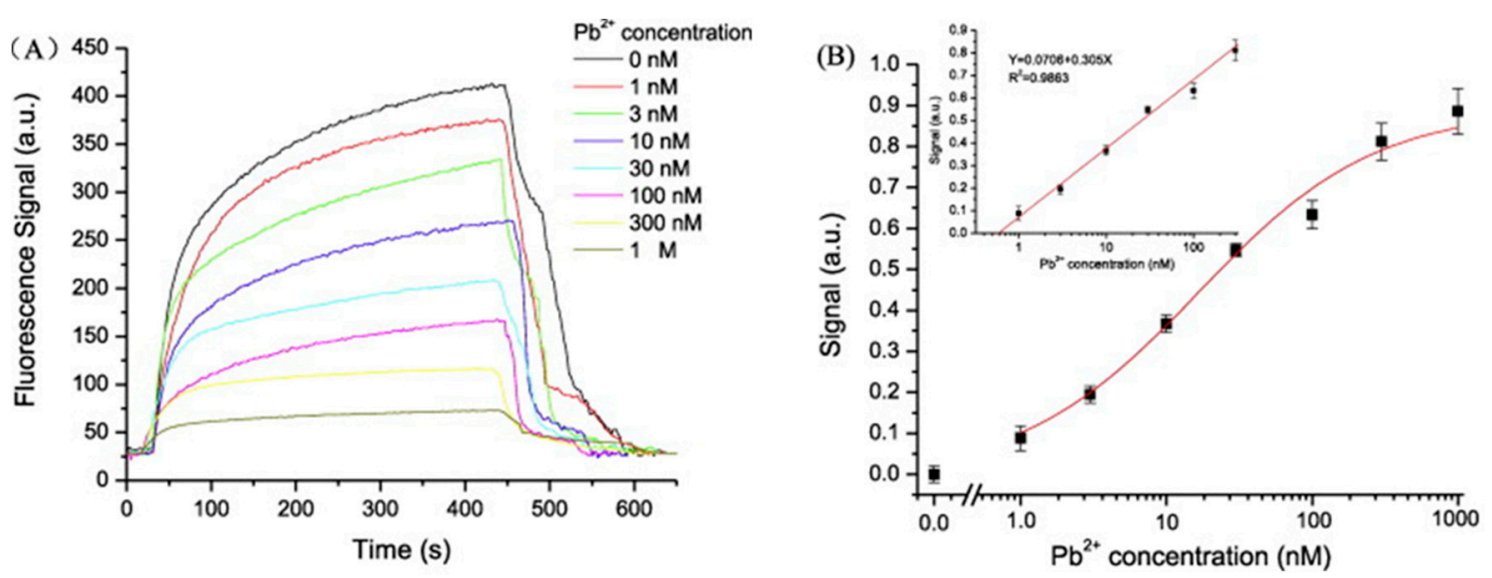

Figure 6. (A) Response curve for different $\mathrm{Pb}^{2+}$ concentrations in the presence of the complementary DNA. (B) Logarithmic calibration curve of the sensor. Reprinted with permission from [75].

There also exist different dyes that are sensitive to the formation of double-stranded DNA (dsDNA), such as PicoGreen [76] and SYBR Green 1 [77]. Utilizing this feature, a fluorescent assay was developed for the detection of $\mathrm{Hg}^{2+}$ and $\mathrm{Ag}^{+}$ions utilizing two complementary strands: $5^{\prime}$-TTCTTTCTTCCCCTTGTTTGTT-3' ${ }^{\prime}$ and 5'-AACAAACAAGGGGAAGAAAGAA-3' [78]. In the absence of both of these metal ions, the two strands formed a dsDNA, which led to the fluorescence emission by PicoGreen. As the $\mathrm{Hg}^{2+}$ or $\mathrm{Ag}^{+}$concentration increased, the number of aptamer/cDNA sequences decreased, resulting in a diminution of the PicoGreen emission. The LOD was $50 \mathrm{nM}$ for

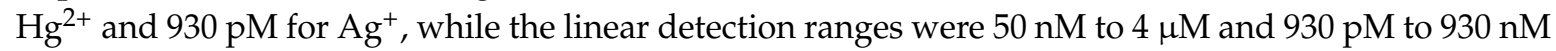
for $\mathrm{Hg}^{2+}$ and $\mathrm{Ag}^{+}$, respectively. Furthermore, not one of the other analyzed metal ions, including $\mathrm{Cu}^{2+}, \mathrm{Li}^{+}, \mathrm{Zn}^{2+}, \mathrm{Na}^{+}, \mathrm{Ca}^{2+}, \mathrm{Mg}^{2+}, \mathrm{K}^{+}$, and $\mathrm{Pb}^{2+}$, interfered in the measurements and, finally, the sensor presented recoveries of the $80-105 \%$ for $\mathrm{Ag}^{+}$and $104-114 \%$ for $\mathrm{Hg}^{2+}$.

As most of the aptamer-based fluorescent sensors for heavy metal ions are focused on $\mathrm{Hg}^{2+}$ and $\mathrm{Pb}^{2+}$ ions detection, the main ones are summarized in Table $1\left(\mathrm{Hg}^{2+}\right)$ and Table $2\left(\mathrm{~Pb}^{2+}\right)$. Due to the high affinity of T-rich and G-rich ON sequences to these ions, and their high toxicity even at trace levels, less attention has been paid to other heavy metal ions. Thus, the development of sensitive and specific $\mathrm{ON}$ sequences for those ions is one of the main challenges for scientists. 
Table 1. $\mathrm{Hg}^{2+}$ fluorescent sensors based on aptamer detection.

\begin{tabular}{|c|c|c|c|c|c|c|c|c|c|c|}
\hline Analyte & ON Sequence & Fluorophore & Quencher & $\begin{array}{l}\text { Detection } \\
\text { Range }\end{array}$ & LOD & Reversibility & $\begin{array}{c}\text { Interferent } \\
\text { Analytes }\end{array}$ & Aqueous Media & Observations & Ref. \\
\hline $\mathrm{Hg}^{2+}$ & $\begin{array}{c}\text { 5-'FAM-CGC TTG TTT GTT } \\
\text { CGC ACC CGT TCT TTC TT-3' }\end{array}$ & FAM & & $\begin{array}{c}14.2 \times 10^{-9} \text { to } \\
3 \times 10^{-7} \mathrm{M}\end{array}$ & $4.28 \times 10^{-9} \mathrm{M}$ & Not studied & $\begin{array}{l}\text { Negligible } \\
\text { influence }\end{array}$ & $\begin{array}{l}\text { Tris-HCl buffer }(10 \mathrm{mM}, \mathrm{pH} \\
8.5)\end{array}$ & & [65] \\
\hline $\mathrm{Hg}^{2+}$ & $\begin{array}{c}5^{\prime}-\mathrm{NH}_{2}-\left(\mathrm{CH}_{2}\right)_{6}- \\
\text { TTCTTTCTTCCCTTGTTTGTT }\end{array}$ & SYBR Green I & & $\begin{array}{l}1 \times 10^{-9} \text { to } \\
1 \times 10^{-2} \mathrm{M}\end{array}$ & Not studied & $93-110 \%$ & Not studied & $\begin{array}{c}\text { Tris nitrate buffer (pH 8.0, } 20 \\
\mathrm{mM})\end{array}$ & & [79] \\
\hline $\mathrm{Hg}^{2+}$ & $\begin{array}{c}\text { 5'-NH }_{2}-\left(\mathrm{CH}_{2}\right)_{6}-\text {-TTCTTTC } \\
\text { TTCGCGTTTTGTT-3' }\end{array}$ & $\begin{array}{l}\text { Graphene oxide } \\
\text { (GO) sheets }\end{array}$ & & $\begin{array}{c}1 \times 10^{-9} \text { to } \\
50 \times 10^{-9} \mathrm{M}\end{array}$ & $9.2 \times 10^{-10} \mathrm{M}$ & Not studied & $\begin{array}{l}\text { Negligible } \\
\text { influence }\end{array}$ & $\begin{array}{l}\text { phosphate-buffered (PBS) } \\
\text { saline }(10 \mathrm{mM}, \mathrm{pH}=7.0)\end{array}$ & & {$[80]$} \\
\hline $\mathrm{Hg}^{2+}$ & $5^{\prime}-\mathrm{NH}_{2}$-TTCTTCCCCTTGTT-3' & $\begin{array}{l}\text { graphite carbon } \\
\text { nitride }\left(\mathrm{g}-\mathrm{C}_{3} \mathrm{~N}_{4}\right) \\
\text { sheets }\end{array}$ & & $\begin{array}{l}5 \times 10^{-10} \text { to } \\
1 \times 10^{-6} \mathrm{M}\end{array}$ & $1.7 \times 10^{-8} \mathrm{M}$ & $98.3-110.8 \%$ & $\begin{array}{l}\mathrm{Cu}^{2+}, \mathrm{Fe}^{3+} \\
\mathrm{Ag}^{+}\end{array}$ & $\begin{array}{l}\text { Detection range, LOD and } \\
\text { interferent analytes calculated } \\
\text { in Tris- } \mathrm{HCl}(\mathrm{pH} 7.6,25 \mathrm{mM}) \\
\text { buffer containing } 150 \mathrm{mM} \\
\text { NaClReversibi-lity studied in } \\
\text { tap water }\end{array}$ & & [81] \\
\hline $\mathrm{Hg}^{2+}$ & $\begin{array}{l}\text { Fam-5'-GGTTGGTGTG } \\
\text { GTTGG-3'-DABCYL) }\end{array}$ & FAM & DABCYL & $\begin{array}{l}1 \times 10^{-8} \text { to } \\
2 \times 10^{-7} \mathrm{M} \\
\end{array}$ & $5 \times 10^{-9} \mathrm{M}$ & $95-104 \%$ & $\mathrm{~Pb}^{2+}$ & Tris-aceta-te $(\mathrm{pH} 7.4,10 \mathrm{mM})$ & & [61] \\
\hline $\mathrm{Hg}^{2+}$ & $\begin{array}{c}\text { 5'-FAM-GGT-TGG-TGT-GGT- } \\
\text { TGG-DABCYL-3' }\end{array}$ & FAM & DABCYL & $\begin{array}{l}1 \times 10^{-8} \text { to } \\
2 \times 10^{-7} \mathrm{M}\end{array}$ & $1 \times 10^{-8} \mathrm{M}$ & Not studied & Not studied & $\begin{array}{c}\text { Tris-acetate buffer (pH 7.4, } 10 \\
\mathrm{mM})\end{array}$ & & [68] \\
\hline $\mathrm{Hg}^{2+}$ & 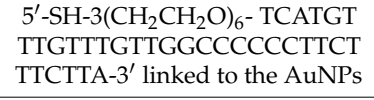 & Texas Red & Au NPs & $\begin{array}{l}1 \times 10^{-11} \text { to } \\
1 \times 10^{-6} \mathrm{M}\end{array}$ & $5.1 \times 10^{-11} \mathrm{M}$ & Not studied & $\begin{array}{l}\text { Negligible } \\
\text { influence }\end{array}$ & $\begin{array}{l}\text { phosphate-buffered saline ( } 10 \\
\mathrm{mM}, \mathrm{pH} \text { 7.0) with } 0.3 \mathrm{M} \mathrm{NaCl}\end{array}$ & $\begin{array}{l}\text { cDNA linked to the } \\
\text { Texas Red }\end{array}$ & [64] \\
\hline $\mathrm{Hg}^{2+}$ & 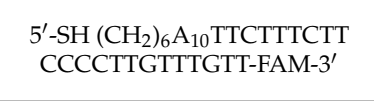 & FAM & Au NPs & $\begin{array}{l}2 \times 10^{-8} \text { to } \\
1 \times 10^{-6} \mathrm{M}\end{array}$ & $1.6 \times 10^{-10} \mathrm{M}$ & Not studied & $\begin{array}{l}\text { Negligible } \\
\text { influence }\end{array}$ & $\begin{array}{l}\text { Tris- } \mathrm{HCl} \text { buffer }(25 \mathrm{mM}, \mathrm{pH} \\
8.2) \text { containing } 0.3 \mathrm{M} \mathrm{NaCl}\end{array}$ & $\begin{array}{l}\text { Aptamer linked to the } \\
\text { Au NPs at the } 5^{\prime} \\
\text { termini }\end{array}$ & [29] \\
\hline $\mathrm{Hg}^{2+}$ & $\begin{array}{c}5^{\prime} \mathrm{NH}_{2}-\mathrm{C}_{6}-\mathrm{CTA} \text { CAG TTT CAC } \\
\text { CTT TTC CCC CGT TTT GGT } \\
\text { GTT T-3' linked to the } \\
\text { NaYF4:Tm } \\
\text { 3it, } \mathrm{Yb}^{3+} \text { UCNPs }\end{array}$ & $\begin{array}{c}\mathrm{NaYF}_{4}: \mathrm{Tm}^{3+}, \mathrm{Yb}^{3+} \\
\text { UCNPs }\end{array}$ & $\mathrm{Au} N \mathrm{NPs}$ & $\begin{array}{l}2 \times 10^{-7} \text { to } \\
2 \times 10^{-5} \mathrm{M}\end{array}$ & $6 \times 10^{-8} \mathrm{M}$ & $95.2-108.2 \%$ & $\begin{array}{l}\text { Negligible } \\
\text { influence }\end{array}$ & $\begin{array}{l}\text { Detection range and LOD } \\
\text { studied in phosphate-buffered } \\
\text { saline }(10 \mathrm{mM}, \mathrm{pH} 7.4) \text { and } \\
\text { reversibility analyzed in milk } \\
\text { and tap water }\end{array}$ & $\begin{array}{l}\text { cDNA linked to the } \\
\text { Au NPs }\end{array}$ & [74] \\
\hline $\mathrm{Hg}^{2+}$ & $\begin{array}{c}5^{\prime}-\mathrm{NH}_{2} \text {-TCATCGTTCTTTCTTC } \\
\text { CCCTTGTTTGTT-3' linked to } \\
\text { the UCNPs }\end{array}$ & $\begin{array}{l}\mathrm{Mn}^{2+} \text {-doped } \\
\text { NaYF }_{4} \text { Y Yb, Er } \\
\text { UCNPs }\end{array}$ & $\begin{array}{c}\mathrm{Au} \\
\text { nanoballs }\end{array}$ & $\begin{array}{l}5 \times 10^{-8} \text { to } \\
5 \times 10^{-7} \mathrm{M}\end{array}$ & $1.5 \times 10^{-10} \mathrm{M}$ & $91.4-102.3 \%$ & $\begin{array}{l}\text { Negligible } \\
\text { influence }\end{array}$ & $\begin{array}{l}25 \mathrm{~g} \text { of real samples of shrimps } \\
\text { or fish dipped in } 225 \mathrm{~mL} \text { of PBS } \\
(\mathrm{pH} 7.4)\end{array}$ & $\begin{array}{l}\text { cDNA-functionalized } \\
\text { Au nanoballs }\end{array}$ & [82] \\
\hline $\mathrm{Hg}^{2+}$ & $\begin{array}{c}5^{\prime}-\mathrm{SH}-\mathrm{C}_{6}-\mathrm{TACAG} \text { TTTCA } \\
\text { CCTTT TCCCC CGTTT TGGTG } \\
\text { TTT-3' linked to Au NPs }\end{array}$ & Mn:CdS/ZnS QDs & Au NPs & $\begin{array}{l}1 \times 10^{-9} \text { to } \\
1 \times 10^{-6} \mathrm{M}\end{array}$ & $1.8 \times 10^{-10} \mathrm{M}$ & Not studied & $\begin{array}{l}\text { Negligible } \\
\text { influence }\end{array}$ & $\begin{array}{c}\text { Tris- } \mathrm{HCl}(\mathrm{pH} 7.4,10 \mathrm{mM}) \\
\text { buffer with } 100 \mathrm{mM} \mathrm{KCl} \text { and } 1 \\
\mathrm{mM} \mathrm{MgCl}_{2}\end{array}$ & $\begin{array}{l}\text { cDNA:5'SH-C }{ }_{6}-\text { TGAAAA }^{\prime} \\
\text { CTGTA-3' linked to } \\
\text { Mn:CdS/ZnS }\end{array}$ & [73] \\
\hline $\mathrm{Hg}^{2+}$ & $\begin{array}{c}5^{\prime} \text {-SH-CGTCTTGTCGA-3' linked } \\
\text { to QDs }\end{array}$ & $\begin{array}{c}\text { Mn-doped } \\
\text { CdS/ZnS } \\
\text { core/shell QDs }\end{array}$ & Au NPs & $\begin{array}{l}1 \times 10^{-9} \text { to } \\
1 \times 10^{-8} \mathrm{M}\end{array}$ & $4.9 \times 10^{-10} \mathrm{M}$ & Not studied & $\begin{array}{l}\text { Negligible } \\
\text { influence }\end{array}$ & PBS buffer (10 mM, pH 7.4) & $\begin{array}{c}\text { cDNA:5'-SH-TCGTCTT } \\
\text { GTCG-3' linked to the } \\
\text { Au NPs }\end{array}$ & [83] \\
\hline $\mathrm{Hg}^{2+}$ & $\begin{array}{c}5^{\prime}-\mathrm{NH}_{2}-\left(\mathrm{CH}_{2}\right)_{6} \text {-TTCTTTCTTC } \\
\text { GCGTTGTTTGTT-3' labeled to } \\
\text { the CDs }\end{array}$ & CQDs & GO & $\begin{array}{l}5 \times 10^{-9} \text { to } \\
2 \times 10^{-7} \mathrm{M}\end{array}$ & $2.6 \times 10^{-9} \mathrm{M}$ & $94.7-109.8 \%$ & $\begin{array}{c}\text { Equal } \\
\text { amount of } \\
\mathrm{Fe}^{2+}\end{array}$ & PBS (10 mM, pH 8.0) & & [84] \\
\hline
\end{tabular}


Table 2. $\mathrm{Pb}^{2+}$ fluorescent sensors based on aptamer detection.

\begin{tabular}{|c|c|c|c|c|c|c|c|c|c|c|}
\hline Analyte & ON Sequence & Fluorophore & Quencher & $\begin{array}{c}\text { Detection } \\
\text { Range }\end{array}$ & LOD & Reversibility & $\begin{array}{c}\text { Interferent } \\
\text { Analytes }\end{array}$ & Aqueous Media & Observations & Ref. \\
\hline $\mathrm{Pb}^{2+}$ & $\begin{array}{c}\left.\text { 5'-Cy5.5-(CH }^{\prime}\right)_{6} \text {-GGGTGGGTG } \\
\text { GGTGGT-3' }\end{array}$ & Cy5.5 & & $\begin{array}{l}1 \times 10^{-9} \text { to } \\
3 \times 10^{-7} \mathrm{M}\end{array}$ & $2.2 \times 10^{-10} \mathrm{M}$ & $80-105 \%$ & $\begin{array}{l}\text { Negligible } \\
\text { influence }\end{array}$ & PBS (10 mM, pH 7.4) & $\begin{array}{l}\text { cDNA: } 5^{\prime}-\mathrm{NH}_{2-}^{-} \\
\left(\mathrm{CH}_{2}\right)_{6}-\text { TTTTTTAC }^{-} \\
\text {CCACCCACCC-3' }^{\prime}\end{array}$ & [75] \\
\hline $\mathrm{Pb}^{2+}$ & 5'-GTGGGTAGGGCGGGTTGG-3' & SYBR Green 1 & & $\begin{array}{l}1 \times 10^{-8} \text { to } \\
1 \times 10^{-6} \mathrm{M}\end{array}$ & Not studied & $98-102.3 \%$ & Not studied & $\begin{array}{c}\text { Tris-HAc buffer (10 mM, } \\
\text { pH 7.4) }\end{array}$ & & [85] \\
\hline $\mathrm{Pb}^{2+}$ & 5'-GGT TGG TGT GGT TGG-3' & PicoGreen (PG) & & $\begin{array}{l}5 \times 10^{-8} \text { to } \\
5 \times 10^{-6} \mathrm{M} \\
\end{array}$ & $4.8 \times 10^{-9} \mathrm{M}$ & Not studied & $\begin{array}{c}\text { Negligible } \\
\text { influence }\end{array}$ & Water & $\begin{array}{l}\text { CDNA: } 5^{\prime}-\text { CCA ACC } \\
\text { ACA CCA ACC- } 3^{\prime}\end{array}$ & [86] \\
\hline $\mathrm{Pb}^{2+}$ & $\begin{array}{c}\text { FAM-5'-GGTTGGTGTGGTTGG- } \\
\text { 3'-DABCYL) }\end{array}$ & FAM & DABCYL & $\begin{array}{l}5 \times 10^{-10} \text { to } \\
3 \times 10^{-8} \mathrm{M}\end{array}$ & $3 \times 10^{-10} \mathrm{M}$ & $95-104 \%$ & $\mathrm{Hg}^{2+}$ & $\begin{array}{l}\text { Tris-aceta-te (pH 7.4, } \\
10 \mathrm{mM})\end{array}$ & & [61] \\
\hline $\mathrm{Pb}^{2+}$ & 5'-FAM-GGTTGGTGTGGTTGG-3' & FAM & $\mathrm{Au}$ NPs & $\begin{array}{l}1.25 \times 10^{-8} \text { to } \\
1 \times 10^{-7} \mathrm{M}\end{array}$ & $1 \times 10^{-8} \mathrm{M}$ & $92-112 \%$ & $\begin{array}{l}\text { Slightly affected } \\
\text { by } \mathrm{Cu}^{2+}, \mathrm{Al}^{2+} \\
\text { and } \mathrm{Hg}^{2+}\end{array}$ & $\begin{array}{c}\text { Tris-HAc buffer }(5 \mathrm{mM}, \mathrm{pH} \\
7.4)\end{array}$ & & [87] \\
\hline $\mathrm{Pb}^{2+}$ & 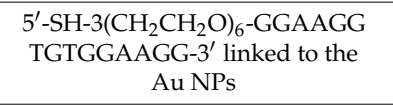 & Cy5.5 & $\mathrm{Au}$ NPs & $\begin{array}{l}1 \times 10^{-11} \text { to } \\
1 \times 10^{-6} \mathrm{M}\end{array}$ & $2.7 \times 10^{-13} \mathrm{M}$ & Not studied & $\begin{array}{l}\text { Negligible } \\
\text { influence }\end{array}$ & $\begin{array}{c}\text { phosphate-buffered saline } \\
(10 \mathrm{mM}, \mathrm{pH} \text { 7) with } 0.3 \mathrm{M} \\
\mathrm{NaCl}\end{array}$ & cDNA linked to Cy5.5 & [64] \\
\hline $\mathrm{Pb}^{2+}$ & $\begin{array}{c}\text { 5'-ATTO647N-GGGTGGG } \\
\text { TGGGTGGGT-3' } \\
\end{array}$ & ATTO647N & SWNTs & $\begin{array}{c}0 \text { to } \\
1 \times 10^{-6} \mathrm{M}\end{array}$ & $4.2 \times 10^{-10} \mathrm{M}$ & Not studied & $\begin{array}{c}\text { Negligible } \\
\text { influence }\end{array}$ & $\begin{array}{c}\text { PBS buffer (10 mM, pH 7) } \\
\text { with } 0.25 \mathrm{M} \mathrm{NaCl}\end{array}$ & & [88] \\
\hline $\mathrm{Pb}^{2+}$ & $\begin{array}{l}\text { 5'-NH2-GGGTGGGTGGGTGGG } \\
\text { T-3' linked to NaYF }{ }_{4}: \mathrm{Yb}, \mathrm{Ho} \\
\text { UCNPs }\end{array}$ & $\begin{array}{l}\mathrm{NaYF}_{4}: \mathrm{Yb}_{\text {, }} \mathrm{Ho} \\
\quad \text { UCNPs }\end{array}$ & Au NRs & $\begin{array}{l}1 \times 10^{-10} \text { to } \\
1 \times 10^{-7} \mathrm{M}\end{array}$ & $5 \times 10^{-11} \mathrm{M}$ & $96.3-110.6 \%$ & $\begin{array}{l}\text { Negligible } \\
\text { influence }\end{array}$ & $\begin{array}{l}25 \mathrm{~g} \text { of real samples of } \\
\text { shrimps or fish dipped in } \\
225 \mathrm{~mL} \text { of PBS (pH 7.4) }\end{array}$ & $\begin{array}{l}\text { cDNA-functionalized } \\
\text { Au NRs }\end{array}$ & [82] \\
\hline $\mathrm{Pb}^{2+}$ & $\begin{array}{c}\text { 5'-NH }_{2}-\left(\mathrm{CH}_{2}\right)_{6} \text {-GGGTGGG } \\
\text { TGGGTGGGT-3' }\end{array}$ & Graphene QDs & GOx & $\begin{array}{l}6 \times 10^{-10} \text { to } \\
4 \times 10^{-7} \mathrm{M}\end{array}$ & $6 \times 10^{-10} \mathrm{M}$ & Not studied & $\begin{array}{l}\text { Negligible } \\
\text { influence }\end{array}$ & $\begin{array}{c}\text { PBS buffer (10.0 mM, pH } \\
7.4)\end{array}$ & & [89] \\
\hline $\mathrm{Pb}^{2+}$ & $\begin{array}{c}5^{\prime}-\mathrm{NH}_{2}-\left(\mathrm{CH}_{2}\right)_{6}-\text { GGGTGGGT } \\
\text { GGGTGGGT-3' }\end{array}$ & CdSe/ZnS QDs & GO sheets & $\begin{array}{l}1 \times 10^{-10} \text { to } \\
1 \times 10^{-8} \mathrm{M}\end{array}$ & $9 \times 10^{-11} \mathrm{M}$ & Not studied & $\begin{array}{l}\text { Negligible } \\
\text { influence }\end{array}$ & PBS buffer (10 mM, pH 7.4) & & [90] \\
\hline $\mathrm{Pb}^{2+}$ & 5'-GGTTGGTGTGGTTGG-3' & $\begin{array}{l}\text { perylenetetracar } \\
\text { boxylic acid } \\
\text { diimide (PTCDI) }\end{array}$ & & $\begin{array}{l}4.8 \times 10^{-10} \text { to } \\
4.8 \times 10^{-5} \mathrm{M}\end{array}$ & $4.8 \times 10^{-10} \mathrm{M}$ & $77.2-93.4 \%$ & $\begin{array}{l}\text { Negligible } \\
\text { influence }\end{array}$ & MOPS buffer (5 mM, pH 7) & & [91] \\
\hline $\mathrm{Pb}^{2+}$ & $\begin{array}{c}\text { 5'-/3ThioMC3-D/CGATAAC } \\
\text { TCACTATrAGGAAGAGATG-3' } \\
\text { linked to the GQDs }\end{array}$ & Graphene QDs & $\mathrm{Au}$ NPs & $\begin{array}{l}5 \times 10^{-8} \text { to } \\
4 \times 10^{-6} \mathrm{M}\end{array}$ & $1.67 \times 10^{-8} \mathrm{M}$ & Not studied & $\begin{array}{l}\text { Negligible } \\
\text { influence }\end{array}$ & $\begin{array}{l}\text { PBS buffer ( } 5 \mathrm{mM}, \mathrm{pH} 7.4) \\
\text { with } 0.1 \mathrm{M} \mathrm{NaCl}\end{array}$ & $\begin{array}{c}\text { 5'-/5AmMC6/CATC }^{\prime} \text { TCTTCTCCGAGCC } \\
\text { GGTCGA-AATAG } \\
\text { TGAGT- } 3^{\prime} \text { linked to } \\
\text { the Au NPs }\end{array}$ & [92] \\
\hline
\end{tabular}




\section{Heavy Metal Ion Sensors Based on Fluorescent Quantum Dots}

Quantum dots (QDs) are nanocrystals [93] that exhibit interesting optical properties, such as narrow and symmetric emission spectra and broad absorption band [94]: both parameters are tunable by modifying their material, shape, and size [95]. Thus, they can be used in a wide range of applications, for instance, photovoltaic devices [96], light-emitting diodes [97], or bioimaging [98].

Fluorescent QDs can be fabricated utilizing semiconductor materials [99,100], carbon [101] or carbon derivatives [102]. Sensing devices can be developed following three main strategies, which are shown in Figure 7: direct interaction between the analyte and the QDs [103], functionalization of the QDs [104,105], and integration of the QDs with other sensory materials [106].

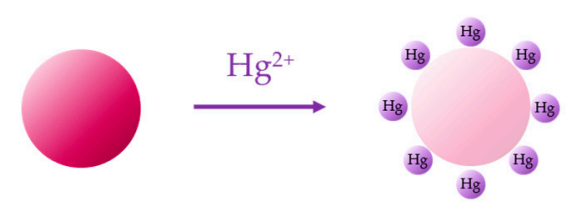

(a)

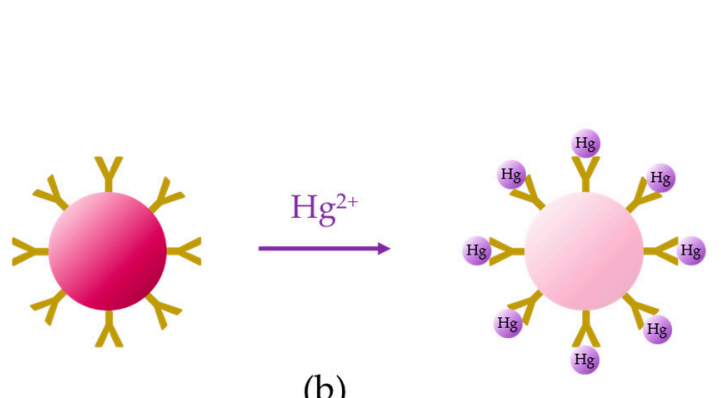

(b)
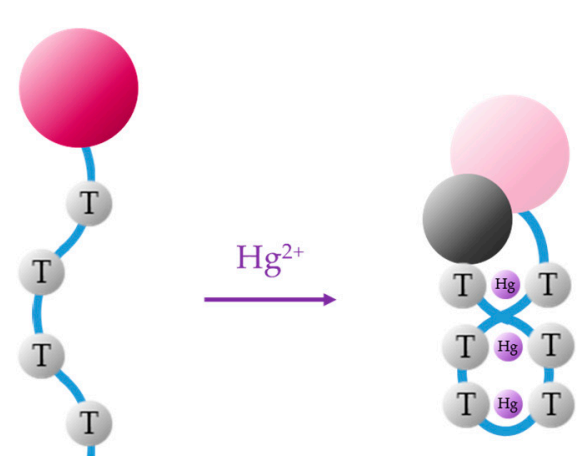

(c)

$\mathrm{Hg}^{2+}$

Fluorescent Quantum Dot

Y Functionalization group
Analyte-sensitive element

Figure 7. Sensing mechanisms based on fluorescent quantum dots: (a) direct interaction between the analyte and the QDs, (b) interaction of the analyte with the functionalized QDs, and (c) integration of the QD with another sensory material.

Among the semiconductor QDs, CdTe QDs have been widely employed for the monitoring of heavy metal ions $[107,108]$. Furthermore, their selectivity and sensitivity can be tuned by utilizing different capping agents [109], such as thioglycolic acid (TGA) or L-cysteine: in the first case, an electron transfer process occurs between the functional groups of TGA and $\mathrm{Hg}^{2+}$ ions, which quenches the luminescent intensity of the CdTe QDs. Thus, employing TGA capped CdTe QDs, it was possible to detect $\mathrm{Hg}^{2+}$ in the nanomolar range, from $1.25 \times 10^{-9} \mathrm{M}$ to $1 \times 10^{-8} \mathrm{M}$, with a LOD of $3.5 \times$ $10^{-10} \mathrm{M} \mathrm{Hg}^{2+}$, as it can be observed in Figure 8a. In the case of L-cysteine capped CdTe QDs, their interaction with $\mathrm{Hg}^{2+}$ ions depends on the concentration of the metal ion: for concentrations of $\mathrm{Hg}^{2+}$ in the picomolar range, these ions interact with the carboxylate moiety of the L-cysteine on the surface of CdTe QDs by electrostatic forces [110]. As a consequence, their luminescent intensity was linearly quenched by the $\mathrm{Hg}^{2+}$ ions from $5 \times 10^{-12} \mathrm{M}$ to $2.5 \times 10^{-11} \mathrm{M}$, as it is displayed in Figure $8 \mathrm{~b}$. Furthermore, the LOD of this sensor was $2.7 \times 10^{-12} \mathrm{M} \mathrm{Hg}^{2+}$. At higher concentrations of $\mathrm{Hg}^{2+}$, there is an electron transfer between the $\mathrm{Hg}^{2+}$ ions and the L-cysteine capped CdTe QDs [111] which induces not only a quenching of the luminescence, but also a red shift in the luminescence peak. Other QDs that show sensitivity to $\mathrm{Hg}^{2+}$ are hyperbranched-graft-copolymers-capped CdS QDs [112], L-cysteine-capped ZnS QDs [113] or polyethylene glycol-capped ZnO QDs [114]. 


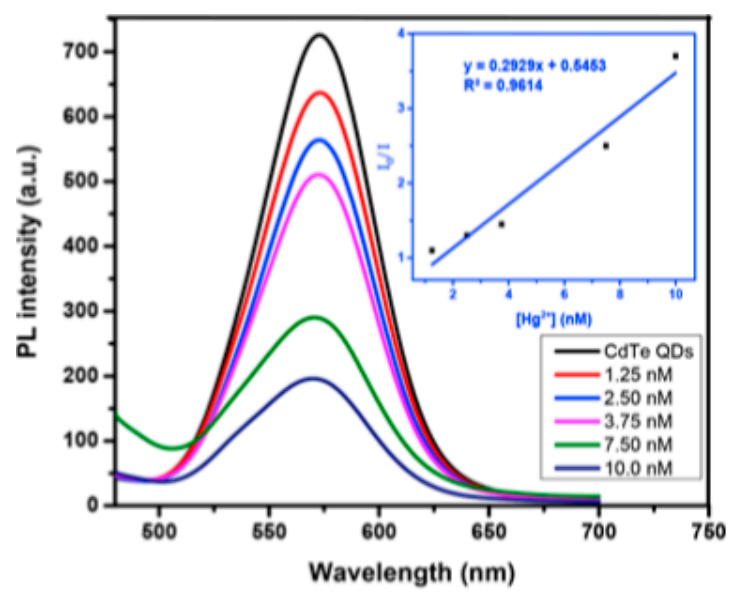

(a)

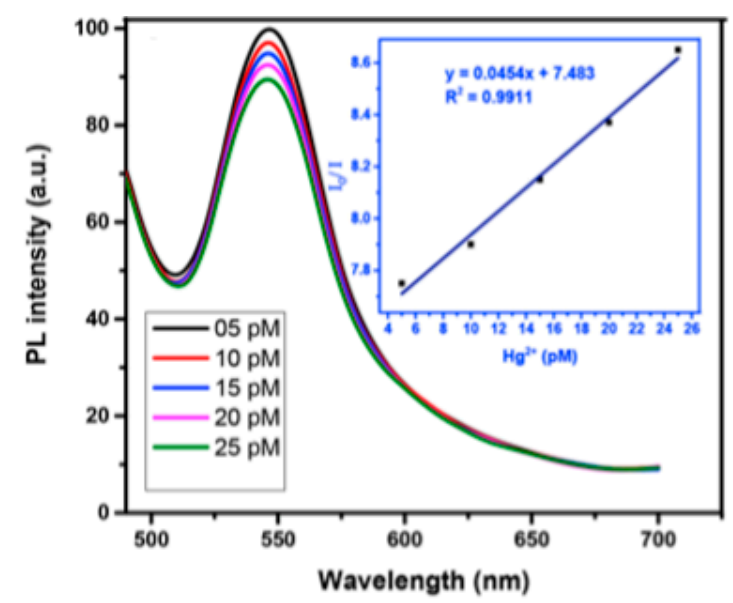

(b)

Figure 8. Fluorescence spectra of (a) TGA and (b) L-cysteine capped CdTe QDs for $\mathrm{Hg}^{2+}$ concentrations in the nanomolar and picomolar ranges, respectively. Reprinted with permission from [109].

Sometimes, these QDs are functionalized with a sensitive element. That is the case of cysteamine-capped CdTe/ZnS core-shell QDs functionalized with T-rich aptamers [115] which, as explained previously, exhibit high affinity for $\mathrm{Hg}^{2+}$ ions. In the absence of $\mathrm{Hg}^{2+}$ ions, these aptamers act as an aggregator agent, resulting in a quenching of the fluorescence. As the $\mathrm{Hg}^{2+}$ concentration increases, T-rich aptamers acquire a hairpin structure and are detached from the QDs, which de-aggregate, giving rise to an increase of the fluorescent intensity. The LOD of this sensor was 8 $\times 10^{-11} \mathrm{M} \mathrm{Hg}^{2+}$, and it was capable of detecting $\mathrm{Hg}^{2+}$ linearly from $5 \times 10^{-10} \mathrm{M}$ to $1 \times 10^{-6} \mathrm{M} \mathrm{Hg}^{2+}$. Taking advantage of the high affinity of thiourea for $\mathrm{Hg}^{2+}$, this compound was used to modify CdSe/ CdS core-shell QDs for the development of a $\mathrm{Hg}^{2+}$ sensor [116] with a LOD of $2.79 \times 10^{-9} \mathrm{M}$ and a linear detection range from $5 \times 10^{-9} \mathrm{M}$ to $1.5 \times 10^{-6} \mathrm{M}$. Although $\mathrm{Cu}^{2+}$ was found as an interferent ion, its presence could be masked with potassium cyanide. Apart from that, the recoveries of the fluorescent emission after removal of $\mathrm{Hg}^{2+}$ were between $83.8 \%$ and $95.4 \%$.

Carbon QDs (CQDs) are a new kind of fluorescent nanomaterials [117] that exhibit several advantages over semiconductor QDs, such as good biocompatibility [118], low toxicity [119], good aqueous solubility [120], or facile synthesis [121].

A common approach to tune their fluorescent properties is by doping them of other elements [122]: nitrogen $(\mathrm{N})$ is the most commonly employed one [123-125], but boron (B), sulfur (S), and phosphorous (P) are also utilized [126-128]. Liu et al. [129] improved the performance of carbon dots by N-doping: although the first ones exhibited a larger linear detection range (from $6 \times 10^{-7}$ to $1.4 \times 10^{-5} \mathrm{M}$, while that of $\mathrm{N}$-doped CQDs was from $0.2-8 \mu \mathrm{M}$ ), their LOD was much lower, $8.7 \times 10^{-8} \mathrm{M}$, opposite to that of $2.5 \times 10^{-7} \mathrm{M}$ of the CQDs, as shown in Figure 9. Furthermore, the $\mathrm{N}$-doping also enhanced the selectivity of the CQDs, avoiding the interference of $\mathrm{Ag}^{+}, \mathrm{Fe}^{3+}, \mathrm{Cu}^{2+}$ and $\mathrm{Cd}^{2+}$ cations. The potential use of N-CQDs in real applications was tested by determining $\mathrm{Hg}^{2+}$ concentrations in real water samples: in the case of mineral water, the recoveries of the N-CQDs were between $96.6 \%$ and $105.5 \%$, while in tap water they ranged from $98.5 \%$ to $105 \%$. 


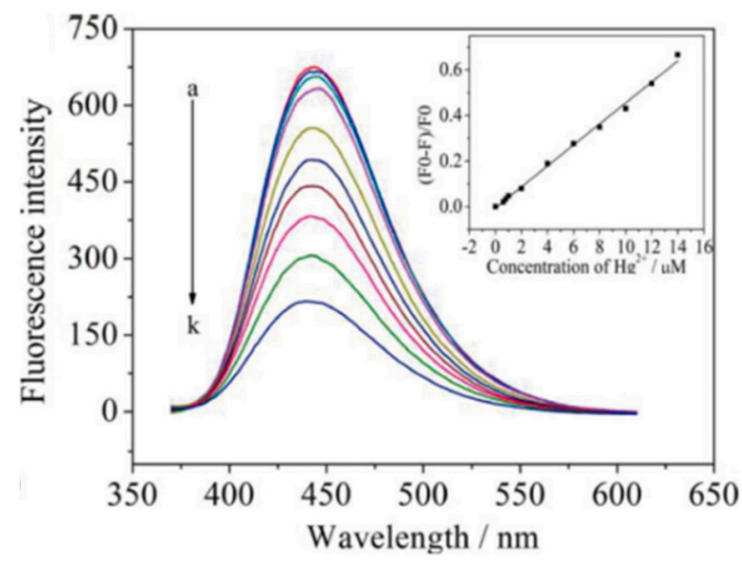

(a)

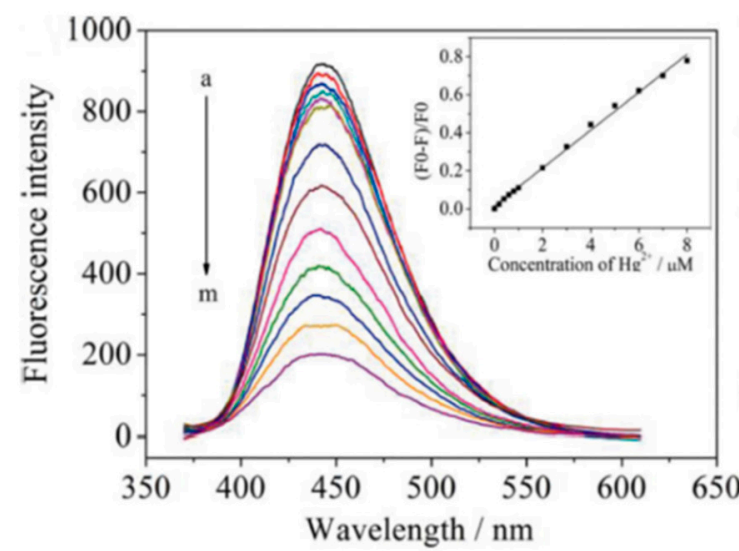

(b)

Figure 9. Fluorescence spectra of $10 \mu \mathrm{g} / \mathrm{mL}$ carbon QDs (a) and N-carbon QDs (b) upon addition of different concentrations of $\mathrm{Hg}^{2+}$ (a-k: $0,0.6,0.8,1,2,4,6,8,10,12$, and $14 \mu \mathrm{M}$; a-m: 0, 0.2, 0.4, 0.6, 0.8, $1,2,3,4,5,6,7$, and $8 \mu \mathrm{M})$. The linear calibration ranges of each one of the sensors are shown in the insets. Reprinted with permission from [129].

While N-dopants improve the quantum yield on CQDs [130], S-dopants are good ligands for metal ions [131]. Thus, S-doped carbon dots have been widely employed for the detection of $\mathrm{Fe}^{3+}$ ions [132-134]. One example is the sensor reported in [135], which exhibited high selectivity for $\mathrm{Fe}^{3+}$ at $\mathrm{pH} 0$. In this acid media, the LOD of the sensor was $9.6 \times 10^{-7} \mathrm{M}$, while the linear detection range was from $2.5 \times 10^{-5}$ to $5 \times 10^{-3} \mathrm{M}$.

In order to enhance the properties of CQDs, they can be doped of several compounds. N-, $\mathrm{S}-$, co-doped carbon dots without any functionalization were fabricated for the linear detection of $\mathrm{Hg}^{2+}$ [136] between 0 and $20 \mu \mathrm{M}$, with a LOD of $1.7 \times 10^{-7} \mathrm{M}$. Additionally, the fluorescent intensity can be linearly recovered by using cyanide anions.

A particular kind of carbon QDs are based on graphene: their features are derived from graphene and carbon nanodots [137]. Hence, their sensing properties can also be modified with dopants such as nitrogen or sulfur [138,139]. In particular, N-, S-codoped graphene QDs-based paper strips have been used in real waste water for the detection of $\mathrm{Hg}^{2+}$ ions [140]: as it can be observed in Figure 10a, the luminescence intensity of the QDs-coated paper strips decreased as the $\mathrm{Hg}^{2+}$ concentration increased from 10 to $200 \mu \mathrm{M}$. Furthermore, concentrations of $100 \mu \mathrm{M}$ of other metal ions $\left(\mathrm{Fe}^{2+}, \mathrm{Mn}^{2+}, \mathrm{Cr}^{3+}, \mathrm{Cd}^{2+}\right.$, $\mathrm{Co}^{2+}$, and $\mathrm{Zn}^{2+}$ ) did not present any interference, as it is displayed in Figure 10b. 
(a)

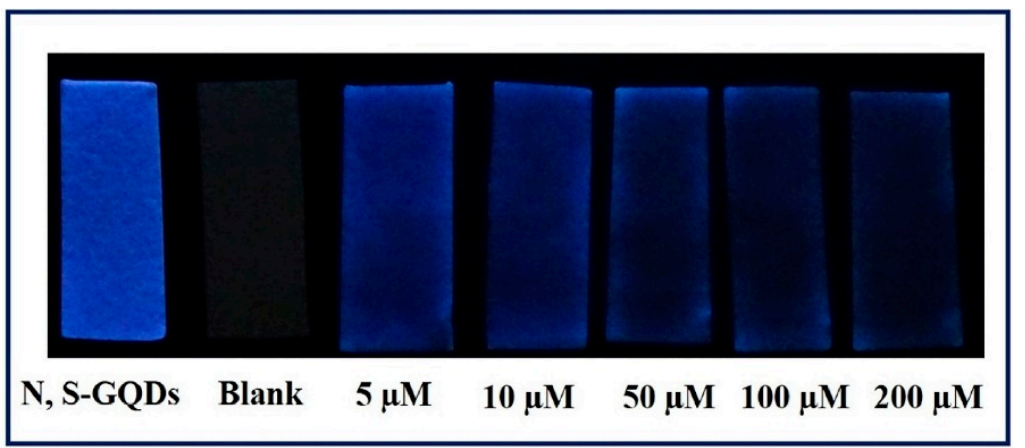

(b)

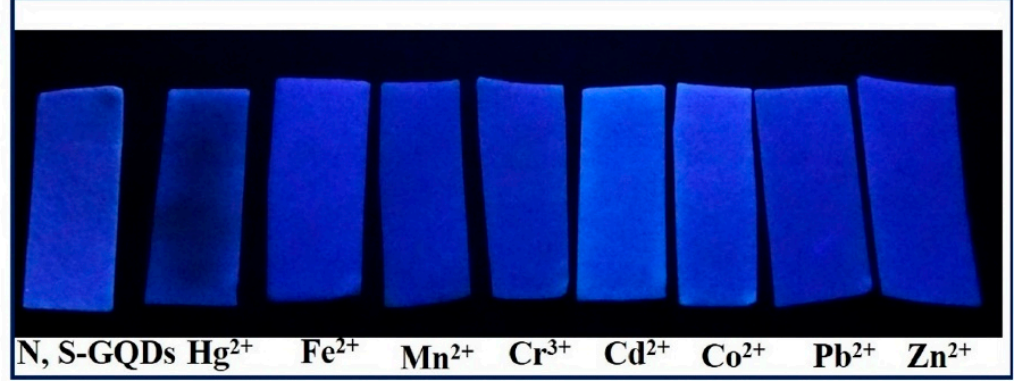

Figure 10. (a) Luminescence of blank paper strips and paper strips coated with $\mathrm{N}-$, S-codoped graphene QDs exposed to different $\mathrm{Hg}^{2+}$ concentrations and (b) in the presence of different metal ions in a 100 $\mu \mathrm{M}$ concentration. Reprinted with permission from [140].

Most of the sensors based on fluorescent QDs have been developed with the purpose of monitoring $\mathrm{Hg}^{2+}$ ions. Thus, Table 3 is focused on this kind of sensors, while devices for other metal ions, are summarized in Table 4. 
Table 3. $\mathrm{Hg}^{2+}$ fluorescent sensors based on QDs.

\begin{tabular}{|c|c|c|c|c|c|c|c|c|}
\hline Analyte & QDs & Detection Range & LOD & Reversibility & Interferent Analytes & Aqueous Media & Observations & Ref. \\
\hline $\mathrm{Hg}^{2+}$ & CdTe QDs & 0 to $2 \times 10^{-6} \mathrm{M}$ & $6.23 \times 10^{-9} \mathrm{M}$ & $96.9-99.4 \%$ & Negligible influence & Ultrapure water & \multirow{5}{*}{$\begin{array}{l}\text { QDs capped with } \\
\text { thioglycolic acid } \\
\text { (TGA) or 1-cysteine }\end{array}$} & [141] \\
\hline $\mathrm{Hg}^{2+}$ & capped CdTe QDs & $\begin{array}{c}\text { (TGA) } 1.25 \times 10^{-9} \text { to } \\
1 \times 10^{-8} \mathrm{M} \\
\text { (1-cysteine) } 5 \times 10^{-12} \text { to } \\
2.5 \times 10^{-11} \mathrm{M}\end{array}$ & $\begin{array}{c}\text { (TGA) } 3.5 \times 10^{-10} \mathrm{M} \\
(1 \text {-cysteine) } \\
2.7 \times 10^{-12} \mathrm{M}\end{array}$ & Not studied & $\begin{array}{l}\text { (TGA) not evaluated } \\
\text { (1-cysteine) } \mathrm{Zn}^{2+}, \mathrm{Cu}^{2+}\end{array}$ & Ultrapure water & & [109] \\
\hline $\mathrm{Hg}^{2+}$ & $\begin{array}{c}\text { Cysteamine (CA)-capped CdTe } \\
\text { QDs }\end{array}$ & $6 \times 10^{-9}$ to $4.5 \times 10^{-7} \mathrm{M}$ & $4 \times 10^{-9} \mathrm{M}$ & $97-106.4 \%$ & $\begin{array}{c}\text { 10-fold } \mathrm{Pb}^{2+}, \mathrm{Cu}^{2+} \text { and } \mathrm{Ag}^{+} \\
<7 \%\end{array}$ & $\begin{array}{l}\text { acetic-acetate buffer } \\
\text { (pH5.0) }\end{array}$ & & [107] \\
\hline $\mathrm{Hg}^{2+}$ & $\begin{array}{l}\text { 1-Tryptophan-capped carbon } \\
\text { quantum dots }\end{array}$ & $1.1 \times 10^{-8}$ to $4 \times 10^{-6} \mathrm{M}$ & $1.1 \times 10^{-8} \mathrm{M}$ & Not studied & Negligible influence & $\begin{array}{l}\text { sodium phosphate buffer } \\
(10 \mathrm{mM}, \mathrm{pH} 6.0)\end{array}$ & & [142] \\
\hline $\mathrm{Hg}^{2+}$ & HPEI-g-HPGs-capped CdS QDs & $1 \times 10^{-8}$ to $1 \times 10^{-4} \mathrm{M}$ & $1.5 \times 10^{-8} \mathrm{M}$ & Not studied & $\mathrm{Cu}^{2+}$ & $\begin{array}{l}\text { Tris-HCl buffer (pH 7.4, } 10 \\
\mathrm{mM})\end{array}$ & & [112] \\
\hline $\mathrm{Hg}^{2+}$ & $\begin{array}{l}\text { MPA coated Mn doped ZnSe/ZnS } \\
\text { colloidal NPs }\end{array}$ & 0 to $2 \times 10^{-8} \mathrm{M}$ & $1 \times 10^{-10} \mathrm{M}$ & Not studied & Negligible influence & PBS (10 mM, pH 7.4) & \multirow{6}{*}{$\begin{array}{l}\text { PDDA eliminates the } \\
\text { interference from } \\
\mathrm{Cu}^{2+} \text { and } \mathrm{Ag}^{+}\end{array}$} & [143] \\
\hline $\mathrm{Hg}^{2+}$ & PDDA-functionalized CdTe QDs & $6 \times 10^{-9}$ to $1 \times 10^{-6} \mathrm{M}$ & $5 \times 10^{-9} \mathrm{M}$ & $97.5-103 \%$ & Negligible influence & Double distilled water & & [144] \\
\hline $\mathrm{Hg}^{2+}$ & $\begin{array}{l}\text { TU-functionalized TGA-capped } \\
\text { CdSe/CdS QDs }\end{array}$ & $5 \times 10^{-9}$ to $1.5 \times 10^{-6} \mathrm{M}$ & $2.79 \times 10^{-9} \mathrm{M}$ & $83.8-95.4 \%$ & Not studied & PBS (pH 7.73) & & [116] \\
\hline $\mathrm{Hg}^{2+}$ & $\mathrm{CdTe} @ \mathrm{SiO}_{2} @ \mathrm{GQDs}$ & $1 \times 10^{-8}$ to $2.2 \times 10^{-5} \mathrm{M}$ & $3.3 \times 10^{-9} \mathrm{M}$ & $107.3-108.7 \%$ & $\mathrm{Fe}^{2+}, \mathrm{Fe}^{3+}$ & PBS (10 mM, pH 7.73) & & [145] \\
\hline $\mathrm{Hg}^{2+}$ & $\begin{array}{l}\text { Carbon QDs blended with } \\
\text { Rhodamine B }\end{array}$ & $1 \times 10^{-7}$ to $4 \times 10^{-5} \mathrm{M}$ & $3 \times 10^{-8} \mathrm{M}$ & $94.5-957 \%$ & glutathione (GSH) & High purity water & & [146] \\
\hline $\mathrm{Hg}^{2+}$ & $\mathrm{N}$-doped carbon QDs & $1 \times 10^{-7}$ to $1 \times 10^{-4} \mathrm{M}$ & $2.3 \times 10^{-8} \mathrm{M}$ & $97.2-103.8 \%$ & GSH & Ultrapure water & & [147] \\
\hline $\mathrm{Hg}^{2+}$ & N-doped carbon QDs & $0.2 \times 10^{-6}$ to $8 \times 10^{-6} \mathrm{M}$ & $8.7 \times 10^{-8} \mathrm{M}$ & $96.6-105.5 \%$ & Negligible influence & PBS (50 mM, pH 7) & \multirow[t]{7}{*}{$\begin{array}{l}\text { Doping with } \mathrm{N} \\
\text { improves the } \\
\text { selectivity }\end{array}$} & [129] \\
\hline $\begin{array}{l}\mathrm{Hg}^{2+} \\
\mathrm{Hg}^{2+}\end{array}$ & $\begin{array}{l}\text { N-doped carbon QDs } \\
\text { N-dopped carbon QDs }\end{array}$ & $\begin{array}{c}0 \text { to } 2.5 \times 10^{-5} \mathrm{M} \\
1 \times 10^{-8} \text { to } 1 \times 10^{-7} \mathrm{M}\end{array}$ & $\begin{array}{l}2.3 \times 10^{-7} \mathrm{M} \\
2.1 \times 10^{-9} \mathrm{M}\end{array}$ & $\begin{array}{l}\text { No } \\
\text { No }\end{array}$ & $\begin{array}{l}\text { Negligible influence } \\
\text { Not studied }\end{array}$ & $\begin{array}{l}\text { Ultra-pure water } \\
\text { PBS }(10 \mathrm{mM}, \mathrm{pH} 7)\end{array}$ & & $\begin{array}{l}{[148]} \\
{[149]}\end{array}$ \\
\hline $\mathrm{Hg}^{2+}$ & N-, S-, Co- doped carbon QDs & 0 to $2 \times 10^{-5} \mathrm{M}$ & $1.8 \times 10^{-7} \mathrm{M}$ & No & $\mathrm{Cu}^{2+}, \mathrm{Ni}^{2+}$ & $\begin{array}{l}\text { Deionized water and } \\
\text { filtered river water }\end{array}$ & & [136] \\
\hline $\mathrm{Hg}^{2+}$ & $\begin{array}{l}\text { S- and O- doped carbon nitride } \\
\text { QDs }\end{array}$ & $1 \times 10^{-8}$ to $1 \times 10^{-6} \mathrm{M}$ & $1 \times 10^{-11} \mathrm{M}$ & Not studied & Negligible influence & $\begin{array}{l}\text { Double distilled water and } \\
\text { tap water }\end{array}$ & & {$[150]$} \\
\hline $\mathrm{Hg}^{2+}$ & Graphene QDs & $8 \times 10^{-7}$ to $9 \times 10^{-6} \mathrm{M}$ & $1 \times 10^{-7} \mathrm{M}$ & Not studied & $\begin{array}{c}\mathrm{Ca}^{2+}, \mathrm{Zn}^{2+}, \mathrm{Fe}^{2+}, \text { and } \mathrm{Co}^{2+} \\
<10 \%\end{array}$ & $\begin{array}{c}\text { Tris-HCl buffer (pH 8, } 50 \\
\mathrm{mM})\end{array}$ & & [151] \\
\hline $\mathrm{Hg}^{2+}$ & O-rich N-doped graphene QDs & $4 \times 10^{-8}$ to $6 \times 10^{-6} \mathrm{M}$ & $8.6 \times 10^{-9} \mathrm{M}$ & $86.7-103.5 \%$ & $\mathrm{~Pb}^{2+}, \mathrm{Cd}^{2+}, \mathrm{Cu}^{2+}$, and $\mathrm{Ni}^{2+}$ & $\begin{array}{c}\text { Tris-HCl buffer (pH 8, } 10 \\
\mathrm{mM})\end{array}$ & & [138] \\
\hline $\mathrm{Hg}^{2+}$ & N-, S-doped graphene QDs & $5 \times 10^{-8}$ to $1.5 \times 10^{-5} \mathrm{M}$ & $1.4 \times 10^{-8} \mathrm{M}$ & $\begin{array}{l}(96 \pm 4.7)- \\
(116 \pm 3.8) \%\end{array}$ & Negligible influence & PBS buffer (100 mM, pH 7) & & [140] \\
\hline
\end{tabular}


Table 4. Fluorescent sensors for different metal ions based on QDs.

\begin{tabular}{|c|c|c|c|c|c|c|c|c|}
\hline Analyte & QDs & Detection Range & LOD & Reversibility & Interferent Analytes & Aqueous Media & Observations & Ref. \\
\hline $\mathrm{Pb}^{2+}$ & $\begin{array}{l}\text { xylenol orange functionalized } \\
\text { CdSe/CdS QDs }\end{array}$ & $5 \times 10^{-8}$ to $6 \times 10^{-6} \mathrm{M}$ & $2 \times 10^{-8} \mathrm{M}$ & $94.8-103.7 \%$ & Negligible influence & PBS (pH 6.47) & & [152] \\
\hline $\mathrm{Pb}^{2+}$ & $\begin{array}{l}\text { green Au NCs covalently linked to } \\
\text { the surface of silica NPs embedded } \\
\text { with red QDs }\end{array}$ & $2.5 \times 10^{-8}$ to $2.5 \times 10^{-7} \mathrm{M}$ & $3.5 \times 10^{-9} \mathrm{M}$ & $95.2-112.4 \%$ & Negligible influence & PBS (50 mM, pH 6) & & [153] \\
\hline $\mathrm{Pb}^{2+}$ & S-doped graphene QDs & $1 \times 10^{-7}$ to $1.4 \times 10^{-4} \mathrm{M}$ & $3 \times 10^{-8} \mathrm{M}$ & Not studied & Negligible influence & PBS (3 mM, pH 7) & & [139] \\
\hline $\mathrm{Pb}^{2+}$ & $\begin{array}{c}\text { Silica-coated } \mathrm{ZnS} \text { QDs }\left(\mathrm{ZnS} @ \mathrm{SiO}_{2}\right. \\
\text { QDs) }\end{array}$ & $1 \times 10^{-9}$ to $2.6 \times 10^{-4} \mathrm{M}$ & - & No & $\mathrm{Cd}^{2+}$ & Deionized water & & [154] \\
\hline $\mathrm{Pb}^{2+}$ & $\begin{array}{c}\text { Flavonoid moiety-incorporated } \\
\text { carbon QDs }\end{array}$ & $1 \times 10^{-10}$ to $2 \times 10^{-8} \mathrm{M}$ & $5.5 \times 10^{-11} \mathrm{M}$ & Not studied & Negligible influence & Deionized water & & [155] \\
\hline $\mathrm{Pb}^{2+}$ & CdTe QDs & $2 \times 10^{-8}$ to $3.6 \times 10^{-6} \mathrm{M}$ & $8 \times 10^{-8} \mathrm{M}$ & Not studied & Negligible influence & Human serum & & [156] \\
\hline $\mathrm{Cu}^{2+}$ & $\begin{array}{l}N \text {-acetyl-1-cysteine capped } \\
\text { CdHgSe QDs }\end{array}$ & $1 \times 10^{-9}$ to $4 \times 10^{-7} \mathrm{M}$ & $2 \times 10^{-10} \mathrm{M}$ & $98.3-101.6 \%$ & $\mathrm{Ag}^{+}, \mathrm{Co}^{2+}, \mathrm{Hg}^{2+}$ & PBS (pH 9) & & [157] \\
\hline $\mathrm{Cu}^{2+}$ & $\begin{array}{l}\text { L-cysteine capped } \mathrm{Mn}^{2+} \text {-doped } \\
\text { ZnS QDs }\end{array}$ & $7.87 \times 10^{-6}$ to $3.15 \times 10^{-4} \mathrm{M}$ & $3.15 \times 10^{-6} \mathrm{M}$ & Not studied & $\mathrm{Hg}^{2+}$ & Phosphate buffer (pH 7) & & [113] \\
\hline $\mathrm{Cu}^{2+}$ & $\begin{array}{c}\text { ligand-capped CdTe QDs (CdTe-L } \\
\text { QDs) }\end{array}$ & $\begin{array}{c}(5.16 \pm 0.07) \times 10^{-8} \text { to }(1.50 \pm \\
0.03) \times 10^{-5} \mathrm{M}\end{array}$ & $\begin{array}{l}(1.55 \pm 0.05) \times \\
10^{-8} \mathrm{M}\end{array}$ & Not studied & Negligible influence & $\begin{array}{l}\text { Tris-HCl buffer (pH 6.5, } 10 \\
\mathrm{mM})\end{array}$ & & [158] \\
\hline $\mathrm{Cu}^{2+}$ & inorganic $\mathrm{CsPbBr} r_{3}$ perovskite QDs & 0 to $1 \times 10^{-7} \mathrm{M}$ & $1 \times 10^{-10} \mathrm{M}$ & Not studied & Negligible influence & $\begin{array}{c}\text { Hexane } \\
\text { Detection range }\end{array}$ & & [159] \\
\hline $\mathrm{Cu}^{2+}$ & $\begin{array}{l}\text { Polyethylene glycol capped ZnO } \\
\text { QDs (PEG@ZnO QDs) }\end{array}$ & $4 \times 10^{-9}$ to $1 \times 10^{-5} \mathrm{M}$ & $3.33 \times 10^{-9} \mathrm{M}$ & $99.6-104.0 \%$ & Negligible influence & $\begin{array}{l}\text { Detection range, LOD and } \\
\text { interferent analytes in } \\
\text { Ultra-pure studied water, } \\
\text { reversibi-lity in tap water }\end{array}$ & & [114] \\
\hline $\mathrm{Cu}^{2+}$ & $\begin{array}{c}\text { Water-soluble silica-coated } \\
\mathrm{ZnS}: \mathrm{Mn} \mathrm{NPs}\left(\mathrm{ZnS}: \mathrm{Mn} / \mathrm{SiO}_{2}\right)\end{array}$ & $8.16 \times 10^{-8}$ to $4.16 \times 10^{-4} \mathrm{M}$ & - & $94.76-105.82 \%$ & Negligible influence & Seawater & & [160] \\
\hline $\mathrm{Fe}^{3+}$ & Carbon QDs & 0 to $3 \times 10^{-4} \mathrm{M}$ & $13.68 \times 10^{-6} \mathrm{M}$ & $\begin{array}{l}\text { With ascorbic } \\
\text { acid }\end{array}$ & Negligible influence & Ultra-pure water & & [161] \\
\hline $\mathrm{Fe}^{3+}$ & $\begin{array}{c}\text { CdTe QDs: } \\
\text { (1) thioglyco-lic acid capped } \\
\text { quantum dots (Green) } \\
\text { (2) N-Acetyl-1-cysteine capped } \\
\text { QDs (red) }\end{array}$ & 0 to $3.5 \times 10^{-6} \mathrm{M}$ & $1.4 \times 10^{-8} \mathrm{M}$ & Not studied & Negligible influence & Deioni-zed water & & [108] \\
\hline $\mathrm{Fe}^{3+}$ & S-doped carbon QDs & $2.5 \times 10^{-5}$ to $5 \times 10^{-3} \mathrm{M}$ & $9.6 \times 10^{-7} \mathrm{M}$ & Not studied & Negligible influence & Ultra-pure water & $\begin{array}{l}\text { It works in strongly } \\
\text { acid }(\mathrm{pH}<2) \\
\text { solutions }\end{array}$ & [135] \\
\hline $\mathrm{Fe}^{3+}$ & N-, B-, S- doped carbon dots & $\begin{array}{l}3 \times 10^{-7} \text { to } 5.46 \times 10^{-4} \mathrm{M} \\
1 \times 10^{-9} \text { to } 4 \times 10^{-9} \mathrm{M}\left(\mathrm{Ho}^{2+}\right)\end{array}$ & $9 \times 10^{-8} \mathrm{M}$ & $97.98-108.55 \%$ & Negligible influence & Tris-HCl buffer (pH 7) & & [162] \\
\hline $\mathrm{Hg}^{2+}, \mathrm{Pb}^{2+}$ & L-cysteine-capped CdS QDs & $\begin{array}{c}\left.1 \times 10^{-9-9} \text { to } 4 \times 10^{-9} \mathrm{M}^{-8} \mathrm{Hg}^{2+}\right) \\
3 \times 10^{-9} \text { to } 1.5 \times 10^{-8} \mathrm{M} \\
\left(\mathrm{Pb}^{2+}\right)\end{array}$ & $\begin{array}{l}1 \times 10^{-9} \mathrm{M}\left(\mathrm{Hg}^{2+}\right) \\
1 \times 10^{-7} \mathrm{M}\left(\mathrm{Pb}^{2+}\right)\end{array}$ & Not studied & Negligible influence & phosphate buffer (pH 7.4) & & [163] \\
\hline $\mathrm{Cr}(\mathrm{III})$ & $\begin{array}{c}\text { ligand-coated CdTe QDs (CdTe-L } \\
\text { QDs) }\end{array}$ & $\begin{array}{c}(6.78 \pm 0.05) \times 10^{-9} \text { to }(3.70 \pm \\
0.02) \times 10^{-6} \mathrm{M}\end{array}$ & $\begin{array}{c}(20.30 \pm 0.03) \times \\
10^{-9} \mathrm{M}\end{array}$ & $98.32-100.50 \%$ & Negligible influence & PBS (10 mM, pH 7) & & [164] \\
\hline $\mathrm{Cd}^{2+}$ & $\begin{array}{l}\text { Green emitting CdSe QDs } \\
\text { covalently linked onto red } \\
\text { emitting CdTe QDs }\end{array}$ & $1 \times 10^{-7}$ to $9 \times 10^{-6} \mathrm{M}$ & $2.5 \times 10^{-9} \mathrm{M}$ & $86.5-102.6 \%$ & Negligible influence & $\begin{array}{c}\text { Detection range, LOD and } \\
\text { interferent analytes studied } \\
\text { in Tris-EDTA. Reversibility } \\
\text { studied in lake water and } \\
\text { tap water }\end{array}$ & & [165] \\
\hline
\end{tabular}




\section{Heavy Metal Ion Sensors Based on Organic Dyes}

Organic dyes have been widely employed for the development of fluorescence-based sensors [166-168] because of their attractive features: high molar extinction coefficient [169], bright signal [170], ease of modification [171], and presence of many possible reactive sites in their skeletons [172]. For the detection of heavy metal ions, these fluorophores are modified with an ion recognition unit (ionophore), which serves as host for the target metal ion (guest) [173]. The interaction between the ionophore and the target analyte induces a modification of the photophysical features of the fluorophore that is translated into a change of its fluorescent emission [174], usually from "off" to "on". Typically employed ionophores are crown ethers [175] and aliphatic or aromatic amines [176], which act as electron donors, that is, they quench the fluorescent emission through a photo-induced electron transfer (PET) mechanism with the fluorophore [177] in the absence of the target metal ion. However, in its presence, PET does not occur, giving rise to an enhancement of the fluorescence intensity, as shown in Figure 11.

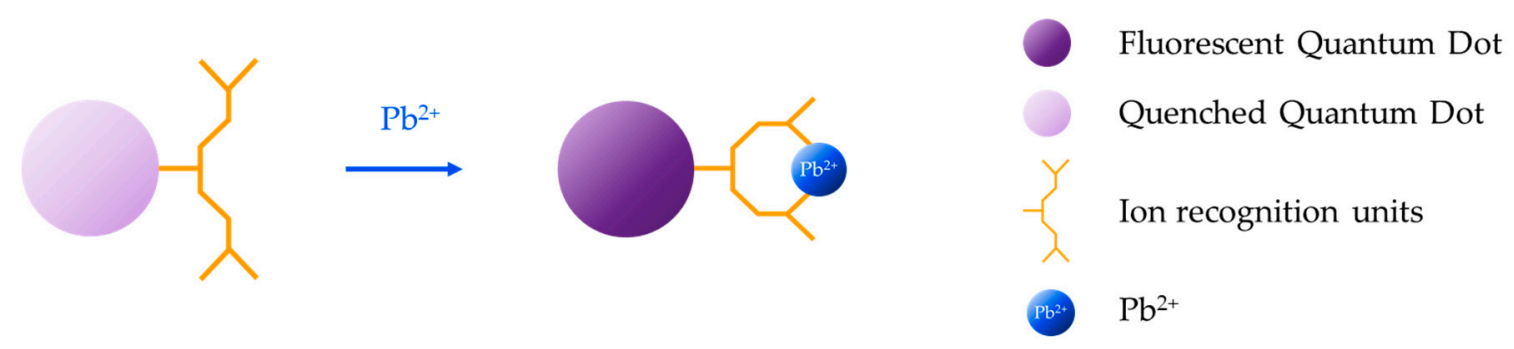

Figure 11. Sensing mechanism based on organic dyes modified with an ion recognition unit: the interaction between the ionophore and the target analyte induces a change in the fluorescent emission of the fluorophore.

Among all of the organic dyes, rhodamine derivatives are the most utilized ones due to their structure-dependent properties [178-180]. Other dyes that are also widely employed for the fabrication of fluorescent sensors are fluorescein [181,182] and coumarin derivatives [183,184].

$\mathrm{Li}$ and co-workers [185] developed a turn-on fluorescent probe for $\mathrm{Hg}^{2+}$ based on a rhodamine $\mathrm{B}$ derivative (rhodamine $\mathrm{B}$ hydroxamate spirolactam) linked to a $\mathrm{NS}_{2}$ unit as a receptor that detected $\mathrm{Hg}^{2+}$ linearly from 0 to $1.6 \times 10^{-5} \mathrm{M}$ with a LOD of $2.36 \times 10^{-6} \mathrm{M}$. The fluorescent response of the sensor towards $\mathrm{Hg}^{2+}$ was not interfered by any other metal ion and the probe was regenerated by using $\mathrm{Na}_{2} \mathrm{~S}$. Furthermore, the potential utilization of this sensor in real applications was tested by exposing the sensor to three natural water samples to which different $\mathrm{Hg}^{2+}$ concentrations were added, as shown in Figure 12. 


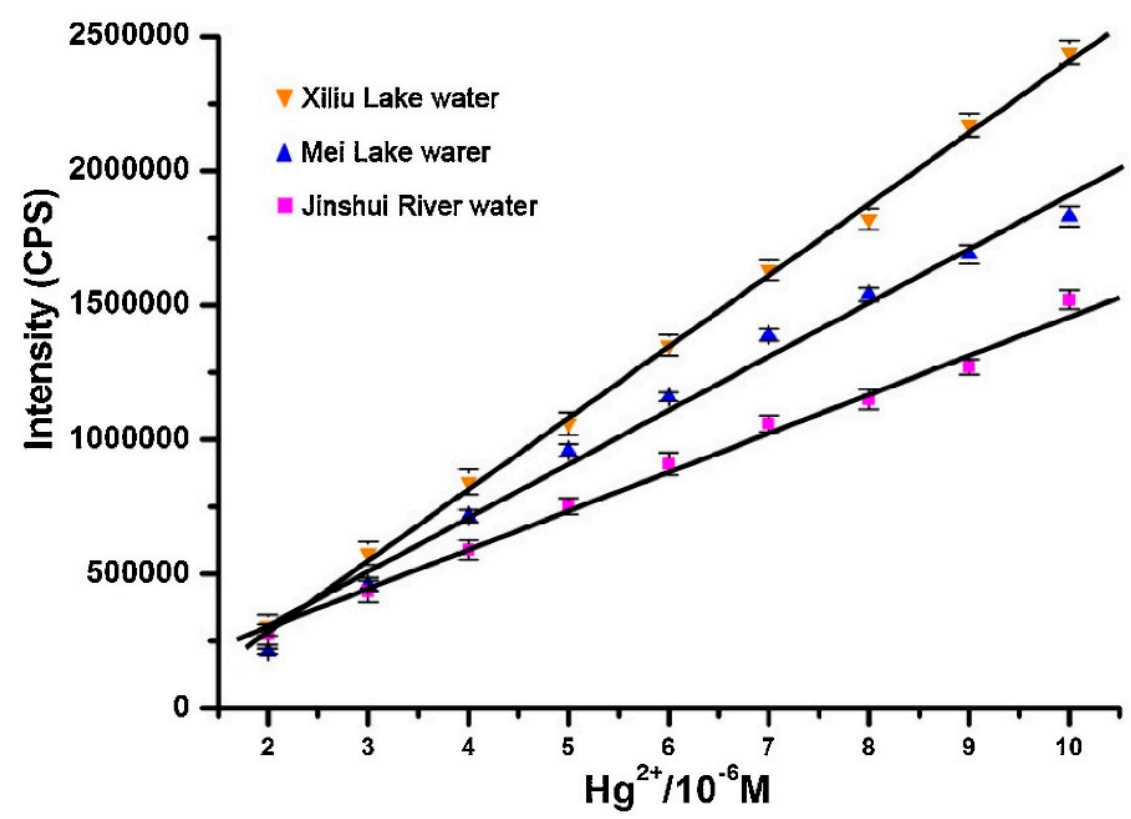

Figure 12. $\mathrm{Hg}^{2+}$ detection carried out by the rhodamine B derivative in three different natural water samples. Reprinted with permission from [185].

Rhod- $5 \mathrm{~N}$ is another rhodamine derivative that consists of a 5N-BAPTA ionophore linked to a rhodamine fluorophore: it exhibits a fluorescence enhancement in the presence of $\mathrm{Hg}^{2+}$ and $\mathrm{Cd}^{2+}$ [186]. Ruan et al. [187] fabricated a $\mathrm{Hg}^{2+}$ sensor by immobilizing it in a silica sol-gel matrix onto the end of an optical fiber: its LOD was $1.25 \times 10^{-7} \mathrm{M} \mathrm{Hg}^{2+}$, and it also presented a linear detection range up to $5 \times 10^{-7} \mathrm{M} \mathrm{Hg}^{2+}$.

Apart from for the detection of $\mathrm{Hg}^{2+}$, rhodamine derivatives have been utilized for monitoring $\mathrm{Cu}^{2+}, \mathrm{Cd}^{2+}$, or $\mathrm{Pb}^{2+}$ ions [188,189]. For instance, a probe based on rhodamine 6G and p-Cresol derivatives [190] exhibited a fluorescence enhancement under the addition of $\mathrm{Pb}^{2+}$ ions when it was illuminated with UV light. Furthermore, the color change promoted by $\mathrm{Pb}^{2+}$ allowed the naked-eye detection of that ion, as shown in Figure 13.

Regarding to fluorescein, it has been shown that the modification of its sites with different functional groups gives rise to sensors of different sensitivities to $\mathrm{Ag}^{+}$ions [191]: when the 4,5-positions of fluorescein were modified with $\mathrm{N}$,Se-containing receptors, the LOD of the sensor was $3 \times 10^{-8} \mathrm{M}$ $\mathrm{Ag}^{+}$, whereas the introduction of a N,S-receptor decreased it up to $4 \times 10^{-9} \mathrm{M}$. In both cases, the presence of $\mathrm{Ag}^{+}$ions induced the opening of the spironolactone ring, which led to the increase of the fluorescence intensity, as shown in Figure 14. 


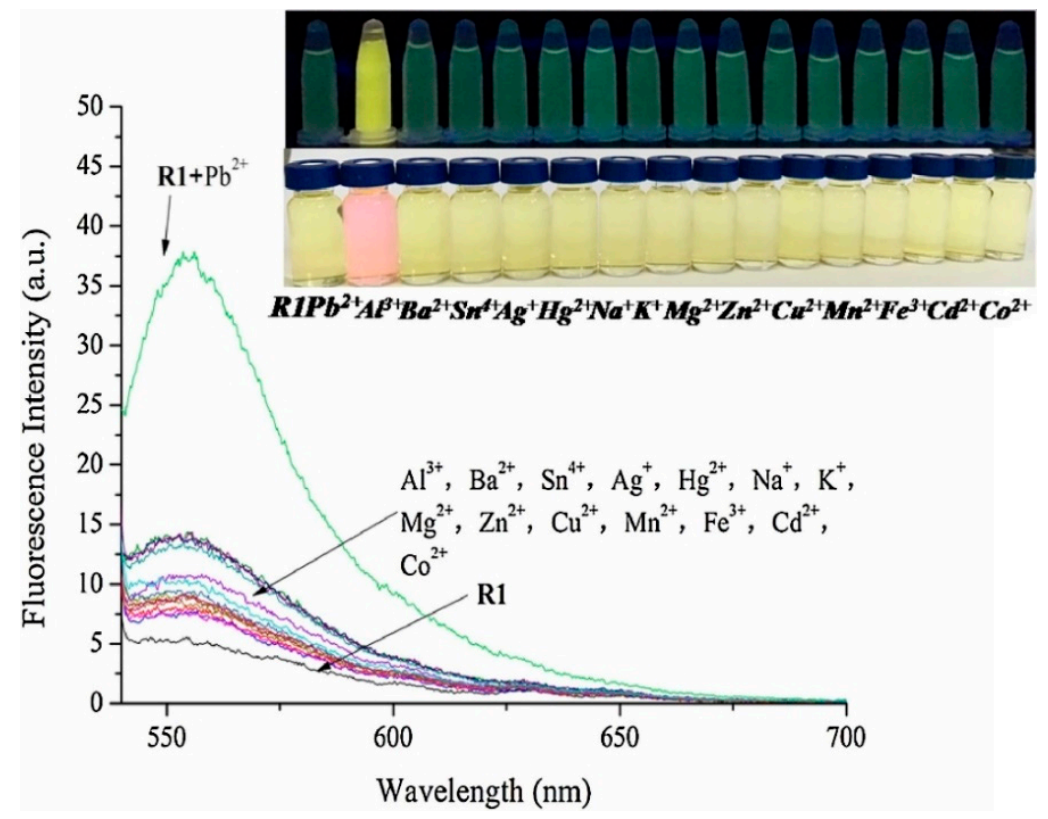

Figure 13. Fluorescence spectra of the probe based on rhodamine $6 \mathrm{G}$ and $\mathrm{p}$-Cresol derivatives in the presence of $\mathrm{Pb}^{2+}\left(1 \times 10^{-5} \mathrm{M}\right)$ and other metal ion $\left(5 \times 10^{-6} \mathrm{M}\right)$. The inset shows the fluorescence under UV illumination and the color change of the probe upon the addition of $\mathrm{Pb}^{2+}$ and other metal ions. Reprinted with permission from [190].
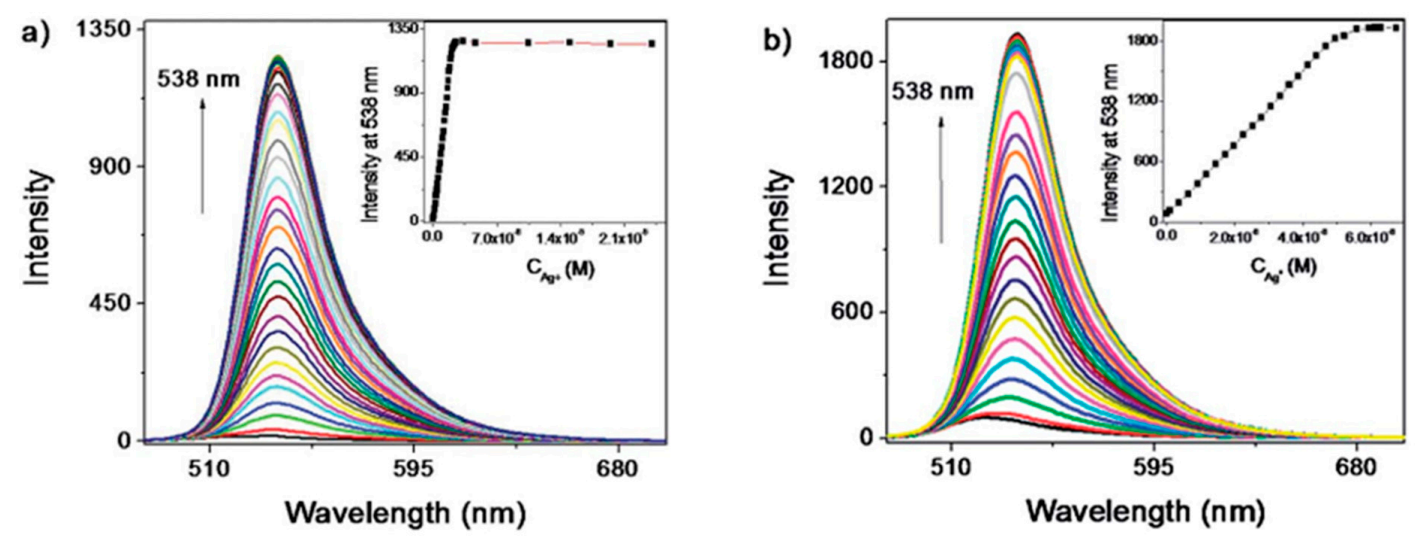

Figure 14. Fluorescence spectra of N,S- and N,Se-modified fluorescein sensors for different $\mathrm{Ag}^{+}$ions in ethanol. Reprinted with permission from [191]. Copyright 2014 Japan Society for Analytical Chemistry.

Another commonly used dye is coumarin, which has been functionalized with receptors that are sensitive to different heavy metal ions: in the case of utilizing a triazole substituted 8-hydroxyquinoline (8-HQ) receptor [192], which exhibits a high affinity towards $\mathrm{Pb}^{2+}$, a highly sensitive $(\mathrm{LOD}=3.36 \times$ $\left.10^{-11} \mathrm{M}\right)$ and selective sensor was developed. In the absence of $\mathrm{Pb}^{2+}$, due the PET mechanism from the receptor to coumarin, the fluorescent emission was weak. In the presence of that metal ion, the PET process did not occur, so the blue emission of coumarin was recovered and visually detectable.

As well as in the case of aptamer- or QDs-based heavy metal ions sensors, most of the devices based on organic dyes are devoted to the detection of $\mathrm{Hg}^{2+}$ ions, whereas those dedicated to the monitoring of other heavy metal ions are not so numerous.

Table 5 summarizes the sensors for $\mathrm{Hg}^{2+}$ detection based on organic dyes, whereas those developed for the detection of other metal ions are outlined in Table 6. 
Table 5. $\mathrm{Hg}^{2+}$ sensors for different metal ions based on organic dyes.

\begin{tabular}{|c|c|c|c|c|c|c|c|c|}
\hline Analyte & Organic Dye & Detection Range & LOD & Reversibility & $\begin{array}{l}\text { Interferent } \\
\text { Analytes }\end{array}$ & Aqueous Media & Observations & Ref. \\
\hline $\mathrm{Hg}^{2+}$ & Rhodamine B & 1 to $5 \times 10^{-8} \mathrm{M}$ & - & Not studied & Negligible influence & Acetonitrile & $\begin{array}{c}\text { Functionalized with } \\
\text { 5-aminoisophthalic acid diethyl } \\
\text { ester }\end{array}$ & [193] \\
\hline $\mathrm{Hg}^{2+}$ & Rhodamine B & 0 to $7 \times 10^{-5} \mathrm{M}$ & - & Not studied & $\begin{array}{l}\mathrm{Zn}^{2+}, \mathrm{Fe}^{2+} \text {, and } \\
\mathrm{Cu}^{2+}\end{array}$ & Water & Functionalized with glucose & [194] \\
\hline $\mathrm{Hg}^{2+}$ & $\begin{array}{l}\text { non-sulfur rhodamine } \\
\text { derivative }\end{array}$ & 0 to $5 \times 10^{-6} \mathrm{M}$ & $2 \times 10^{-7} \mathrm{M}$ & Yes & Negligible influence & Acetonitrile & $\begin{array}{l}\text { Functionalized with ethylene } \\
\text { moiety }\end{array}$ & [195] \\
\hline $\mathrm{Hg}^{2+}$ & $\begin{array}{l}\text { Rhodamine B (RBAI) } \\
\text { Rhodamine 6G (RGAI) }\end{array}$ & $\begin{array}{l}\text { RBAI- } 5 \times 10^{-6} \text { to } \\
2.2 \times 10^{-5} \mathrm{M} \\
\text { RGAI- } 7.94 \times 10^{-6} \\
\text { to } 2.5 \times 10^{-5} \mathrm{M}\end{array}$ & $\begin{array}{l}\text { RBAI-4.23 } \times 10^{-6} \mathrm{M} \\
\text { RGAI-6.34 × } 10^{-6} \mathrm{M}\end{array}$ & $>90 \%$ & Negligible influence & $\begin{array}{l}\text { Detection range, LOD, reversibility } \\
\text { and interferent analytes studied in } \\
\text { ethanol-water }(4 / 6 v / v, 20 \mathrm{mM} \text {, } \\
\text { HEPES pH 7.4). Detection also } \\
\text { tested in living cells and mice }\end{array}$ & $\begin{array}{l}\text { Functionalized with } \\
\text { di-Aminobenzene-phenyl } \\
\text { Isothiocyanate }\end{array}$ & [196] \\
\hline $\mathrm{Hg}^{2+}$ & Rhodamine $B$ derivative & 0 to $1.6 \times 10^{-5} \mathrm{M}$ & $2.36 \times 10^{-6} \mathrm{M}$ & Yes & Negligible influence & $\begin{array}{l}\text { Detection range, LOD, reversibility } \\
\text { and interferent analytes studied in } \\
\text { deionized water. Potential } \\
\text { application analyzed in three } \\
\text { natural water samples. }\end{array}$ & $\begin{array}{l}\text { Functionalized with } \\
\mathrm{NS}_{2} \text {-containing receptor }\end{array}$ & [185] \\
\hline $\mathrm{Hg}^{2+}$ & Rhodamine derivative & 0 to $6 \times 10^{-4} \mathrm{M}$ & $6.79 \times 10^{-6} \mathrm{M}$ & Not studied & Negligible influence & $\begin{array}{c}\text { DMSO-HEPES buffer }(0.02 \mathrm{~mol} / \mathrm{L}, \\
\text { pH } 7.4 ; v / v=6: 4)\end{array}$ & $\begin{array}{l}\text { Functionalized with } \\
\text { hydroxyquinoline group }\end{array}$ & [197] \\
\hline $\mathrm{Hg}^{2+}$ & Rhod-5N & 0 to $3 \times 10^{-7} \mathrm{M}$ & $1.5 \times 10^{-9} \mathrm{M}$ & Not studied & Not studied & $\begin{array}{c}\text { Milli-Q water } \\
\text { Mill }\end{array}$ & $\begin{array}{l}\text { nyaroxyquinomne group } \\
\text { Functionalized with BAPTA }\end{array}$ & [187] \\
\hline $\mathrm{Hg}^{2+}$ & Rhodamine C & $\begin{array}{c}4 \times 10^{-7} \text { to } 5 \times 10^{-6} \\
\mathrm{M}\end{array}$ & $7.4 \times 10^{-8} \mathrm{M}$ & Yes $\left(\mathrm{Na}_{2} \mathrm{~S}\right.$ addition $)$ & Negligible influence & $\begin{array}{l}\text { buffered HEPES }(20 \mathrm{mM}, \mathrm{pH} 7.0) \\
\text { water-ethanol }(7 / 3, v / v)\end{array}$ & $\begin{array}{l}\text { synthesized by the reaction of } \\
\text { rhodamine ethylenediamine and } \\
\text { cinnamoyl chloride }\end{array}$ & [198] \\
\hline $\mathrm{Hg}^{2+}$ & $\begin{array}{l}\text { Rhodamine B derivatives } \\
\text { RW-1, RW-2 }\end{array}$ & $\begin{array}{l}\text { RW-1: } 5 \times 10^{-7} \text { to } 3 \\
\times 10^{-6} \mathrm{M} \\
\text { RW-2: } 5 \times 10^{-7} \text { to } 4 \\
\quad \times 10^{-6} \mathrm{M}\end{array}$ & $\begin{array}{l}\text { RW-1: } 2.5 \times 10^{-8} \mathrm{M} \\
\text { RW-2: } 4.2 \times 10^{-8} \mathrm{M}\end{array}$ & Yes & Negligible influence & $\begin{array}{c}4: 6 \mathrm{CH}_{3} \mathrm{OH} / \mathrm{HEPES} \text { buffer }(v / v, 10 \\
\mathrm{mM}, \mathrm{pH} 7.0)\end{array}$ & $\begin{array}{l}\text { Functionalized with a spirocyclic } \\
\text { moiety }\end{array}$ & [199] \\
\hline $\mathrm{Hg}^{2+}$ & $\begin{array}{l}\text { RR1-rhodamine- } \\
\text { rhodanine-based }\end{array}$ & 0 to $12 \times 10^{-6} \mathrm{M}$ & $5 \times 10^{-9} \mathrm{M}$ & No & Negligible influence & water-ACN $(60 / 40 v / v)$ mixture & & [200] \\
\hline $\begin{array}{l}\mathrm{Hg}^{2+} \\
\mathrm{Pb}^{2+}, \mathrm{Cd}^{2+}\end{array}$ & rhodamine $6 \mathrm{G}$ hydrazide & $\begin{aligned} \mathrm{Hg}^{2+}: 1 \times 10^{-5} \text { to } 5 \times \\
10^{-5} \mathrm{M} \\
\mathrm{Pb}^{2+}: 1 \times 10^{-5} \text { to } 7 \times \\
10^{-5} \mathrm{M} \\
\mathrm{Cd}^{2+}: 1 \times 10^{-5} \text { to } 9 \times \\
10^{-5} \mathrm{M}\end{aligned}$ & $\begin{array}{l}\mathrm{Hg}^{2+}: 1.6 \times 10^{-8} \mathrm{M} \\
\mathrm{Pb}^{2+}: 1.2 \times 10^{-8} \mathrm{M} \\
\mathrm{Cd}^{2+}: 4.7 \times 10^{-8} \mathrm{M}\end{array}$ & $\begin{array}{l}\text { Yes: } \mathrm{Hg}^{2+} \text { and } \mathrm{Cd}^{2+} \\
\text { (with EDTA) } \\
\text { No: } \mathrm{Pb}^{2+}\end{array}$ & $\begin{array}{l}\mathrm{Cu}^{2+} \text { and } \mathrm{Ni}^{2+} \text { in } \\
\text { the case of } \mathrm{Cd}^{2+} \\
\text { detection }\end{array}$ & $\begin{array}{l}\text { HEPES buffer solution (EtOH: } \mathrm{H}_{2} \mathrm{O} \\
=9 / 1,10 \mathrm{mM} \text { HEPES buffer, } \mathrm{pH} \\
7.2)\end{array}$ & $\begin{array}{l}\text { Functionalized with } \\
\mathrm{N} \text {-methylisatin }\end{array}$ & [189] \\
\hline $\mathrm{Hg}^{2+}$ & $\begin{array}{l}\text { Fluorescein and rhodamine } \\
\text { B }\end{array}$ & $\begin{array}{c}2.5 \times 10^{-7} \text { to } 2.52 \times \\
10^{-6} \mathrm{M}\end{array}$ & $2.02 \times 10^{-8} \mathrm{M}$ & Yes & Negligible influence & Dichlorome-thane & & [201] \\
\hline $\mathrm{Hg}^{2+}$ & Coumarine derivative & 0 to $1.4 \times 10^{-5} \mathrm{M}$ & - & $\begin{array}{l}\text { Yes (after TPEN } \\
\text { incubation) }\end{array}$ & Negligible influence & Deionized water & $\begin{array}{l}\text { Modified with azathia crown ether } \\
\text { moiety }\end{array}$ & [202] \\
\hline $\mathrm{Hg}^{2+}$ & rhodol-coumarin & 0 to $2.5 \times 10^{-5} \mathrm{M}$ & $5.5 \times 10^{-9} \mathrm{M}$ & Not studied & $\begin{array}{l}\text { Negligible influence } \\
\mathrm{Co}^{2+} \mathrm{Ni}^{2+} \text { and }\end{array}$ & MeOH- $\mathrm{H}_{2} \mathrm{O}(v / v=1: 1)$ solution & Modified with hydrazide moiety & [203] \\
\hline $\mathrm{Hg}^{2+}$ & coumarin & 0 to $4 \times 10^{-6} \mathrm{M}$ & $1 \times 10^{-5} \mathrm{M}$ & No & $\begin{array}{l}\mathrm{Cu}^{2+}+(\mathrm{can} \text { me } \\
\text { masked by using } \\
\text { EDTA) }\end{array}$ & $\begin{array}{c}\text { HEPES buffer solution }(20 \mathrm{mM} \\
\text { HEPES, pH 7.2, EtOH: } \mathrm{H}_{2} \mathrm{O}=1: 1, \\
v / v)\end{array}$ & $\begin{array}{l}\text { thiosemicarbazide } \\
\text { derivative reacts with } \mathrm{Hg}^{2+}\end{array}$ & [204] \\
\hline
\end{tabular}


Table 5. Cont

\begin{tabular}{|c|c|c|c|c|c|c|c|c|}
\hline Analyte & Organic Dye & Detection Range & LOD & Reversibility & $\begin{array}{c}\text { Interferent } \\
\text { Analytes }\end{array}$ & Aqueous Media & Observations & Ref. \\
\hline $\mathrm{Hg}^{2+}$ & $\begin{array}{c}\text { dibenzo-18-crown-6-ether } \\
\text { (DB18C6) }\end{array}$ & $\begin{array}{c}1.25 \times 10^{-6} \text { to } 1.2 \times \\
10^{-4} \mathrm{M}\end{array}$ & $1.25 \times 10^{-8} \mathrm{M}$ & Not studied & $\mathrm{Cu}^{2+}, \mathrm{Pb}^{2+}$ & Titrisol buffer (pH 7) & & {$[205]$} \\
\hline $\mathrm{Hg}^{2+}$ & $\begin{array}{l}\text { 2-((2-(vinyloxy)-naphthalen- } \\
\text { 1-yl)methylene) } \\
\text { malononitrile }\end{array}$ & 0 to $5 \times 10^{-6} \mathrm{M}$ & $4.31 \times 10^{-8} \mathrm{M}$ & Not studied & Negligible influence & $\begin{array}{c}\text { PBS buffer }(10 \\
\mathrm{mM}, \mathrm{pH} 7.4 \text {, containing } 1 \% \\
\left.\mathrm{CH}_{3} \mathrm{CN}\right)\end{array}$ & & [206] \\
\hline $\mathrm{Hg}^{2+}$ & Dansyl-Met-NH ${ }_{2}$ & $\begin{array}{c}1 \times 10^{-8} \text { to } 6 \times 10^{-6} \\
\mathrm{M}\end{array}$ & $5 \times 10^{-9} \mathrm{M}$ & Yes & $\begin{array}{c}\text { Potentital } \\
\text { interference from } \\
\mathrm{Fe}^{2+}, \mathrm{Pb}^{2+}, \mathrm{Cd}^{2+}, \\
\mathrm{Pd}^{2+}\end{array}$ & $\begin{array}{l}\text { HEPES buffer }(10 \mathrm{mM}, \mathrm{pH} 7.4) \text {. } \\
\text { Potential application also studied } \\
\text { in synthetic marine water }\end{array}$ & & [207] \\
\hline
\end{tabular}

Table 6. Fluorescent sensors for different metal ions based on organic dyes.

\begin{tabular}{|c|c|c|c|c|c|c|c|c|}
\hline Analyte & Organic Dye & Detection Range & LOD & Reversibility & $\begin{array}{c}\text { Interferent } \\
\text { Analytes }\end{array}$ & Aqueous Media & Observations & Ref. \\
\hline $\mathrm{Pb}^{2+}$ & Rhodamine 6G derivative & $\begin{array}{c}1 \times 10^{-8} \text { to } 1 \times 10^{-5} \\
\mathrm{M}\end{array}$ & $2.7 \times 10^{-9} \mathrm{M}$ & Yes & Negligible influence & $\begin{array}{l}\text { HEPES buffer (10 mM, pH 7.4). } \\
\text { Also tested in sea shells food. }\end{array}$ & $\begin{array}{l}\text { Recognition moiety attached to the } \\
\text { R- } 6 \mathrm{G} \text { derivative }\end{array}$ & [190] \\
\hline $\mathrm{Pb}^{2+}$ & $\begin{array}{l}\text { rhodamine } \\
\text { tri methoxy benzaldehyde } \\
\text { conjugate derivative }\end{array}$ & 0 to $1 \times 10^{-5} \mathrm{M}$ & $1.5 \times 10^{-8} \mathrm{M}$ & Not studied & Negligible influence & HEPES buffer solution ( $\mathrm{pH} 7.54$ ) & & [208] \\
\hline $\mathrm{Pb}^{2+}$ & $\begin{array}{l}\text { rhodamine hydroxamate } \\
\text { derivative }\end{array}$ & 0 to $1 \times 10^{-5} \mathrm{M}$ & $2.5 \times 10^{-7} \mathrm{M}$ & $\begin{array}{l}\text { Yes (adding } \\
\text { EDTA) }\end{array}$ & Negligible influence & HEPES buffer (10 mM, pH 6.5) & $\begin{array}{l}\text { Functionalized with an acyclic diethyl } \\
\text { iminodiacetate receptor }\end{array}$ & {$[188]$} \\
\hline $\mathrm{Pb}^{2+}$ & Coumarin & 0 to $2 \times 10^{-5} \mathrm{M}$ & $1.9 \times 10^{-9} \mathrm{M}$ & Not studied & Negligible influence & $\begin{array}{l}\text { phosphate-buffer }(20 \mathrm{mM}, 1: 9 \\
\left.\text { DMSO } / \mathrm{H}_{2} \mathrm{O}(v / v), \mathrm{pH} 8.0\right)\end{array}$ & $\begin{array}{l}\text { Coumarin-trizaole-based receptor: } \\
\text { (4-((1-(2-oxo-2H-chromen-4-yl)-1H-1,2,3- } \\
\text { triazol-5-yl)methoxy)-2H-chromen-2-one) }\end{array}$ & [209] \\
\hline $\mathrm{Pb}^{2+}$ & Coumarin & $\begin{array}{c}6 \times 10^{-6} \text { to } 2 \times 10^{-5} \\
\mathrm{M}\end{array}$ & $3.36 \times 10^{-11} \mathrm{M}$ & Not studied & Negligible influence & $\begin{array}{c}\text { HEPES buffer solution } \\
\left(\mathrm{CH}_{3} \mathrm{CN}: \mathrm{H}_{2} \mathrm{O}=95: 5, v / v, 10 \mathrm{mM},\right. \\
\text { pH 7.2) }\end{array}$ & $\begin{array}{l}\text { Functionalized with a triazole } \\
\text { substituted 8-hydroxyquinoline } \\
\text { (8-HQ) receptor }\end{array}$ & [192] \\
\hline $\mathrm{Pb}^{2+}$ & BODIPY fluorophore & $\begin{array}{c}5 \times 10^{-8} \text { to } 2.5 \times \\
10^{-6} \mathrm{M}\end{array}$ & $1.34 \times 10^{-8} \mathrm{M}$ & Not studied & Negligible influence & PBS buffer (0.1 M, pH 7.2) & $\begin{array}{l}\text { Functionalized with a polyamide } \\
\text { receptor }\end{array}$ & [210] \\
\hline $\mathrm{Pb}^{2+}$ & 1,3,6-trihydroxy xanthone & $\begin{array}{c}1 \times 10^{-5} \text { to } 2 \times 10^{-4} \\
\mathrm{M}\end{array}$ & $1.8 \times 10^{-7} \mathrm{M}$ & Not studied & - & $\begin{array}{c}\text { DMSO- } \mathrm{H}_{2} \mathrm{O} \text { solution (2:1 ratio, } \\
v / v)\end{array}$ & & [211] \\
\hline $\mathrm{Pb}^{2+}$ & $\begin{array}{l}\text { 2-amino-4-phenyl-4H-benzo } \\
\text { [h]chromene-3-carbonitrile }\end{array}$ & 0 to $2 \times 10^{-3} \mathrm{M}$ & $4.14 \times 10^{-4} \mathrm{M}$ & Yes & $\begin{array}{l}\mathrm{Cd}^{2+}, \mathrm{Fe}^{3+}, \mathrm{Hg}^{2+}, \\
\mathrm{Cu}^{2+}\end{array}$ & Methanol & & [212] \\
\hline $\mathrm{Cu}^{2+}$ & $\begin{array}{l}\text { rhodamine B } \\
\text { semicarbazide }\end{array}$ & $\begin{array}{c}2 \times 10^{-8} \text { to } 3 \times 10^{-7} \\
\mathrm{M}\end{array}$ & $1.6 \times 10^{-7} \mathrm{M}$ & Not studied & Negligible influence & Methanol-water $(1: 1, v / v)$ at $\mathrm{pH} 7$ & & [213] \\
\hline $\mathrm{Cu}^{2+}$ & $\begin{array}{l}\text { rhodamine hydroxamate } \\
\text { derivative }\end{array}$ & 0 to $1.2 \times 10^{-5} \mathrm{M}$ & $5.8 \times 10^{-7} \mathrm{M}$ & $\begin{array}{l}\text { Yes }\left(\mathrm{Na}_{2} \mathrm{~S}\right. \\
\text { addition) }\end{array}$ & Negligible influence & $\begin{array}{c}\text { HEPES buffer }(10 \mathrm{mM}, \mathrm{pH} 6.5) \\
\text { containing } 1 \% \mathrm{CH}_{3} \mathrm{CN}(v / v)\end{array}$ & $\begin{array}{l}\text { Functionalized with an acyclic diethyl } \\
\text { iminodiacetate receptor }\end{array}$ & {$[188]$} \\
\hline $\mathrm{Cu}^{2+}$ & $\begin{array}{l}\text { 6,7-dihydroxy-3-(3- } \\
\text { chlorophenyl) coumarin }\end{array}$ & 0 to $2.5 \times 10^{-6} \mathrm{M}$ & $3.3 \times 10^{-10} \mathrm{M}$ & Yes (with $S^{2-}$ ) & Negligible influence & $\mathrm{CH}_{3} \mathrm{CN} / \mathrm{H}_{2} \mathrm{O}(90: 10, v / v)$ & & [214] \\
\hline $\mathrm{Cu}^{2+}$ & Fluorescein & $\begin{array}{c}1 \times 10^{-6} \text { to } 6 \times 10^{-5} \\
\mathrm{M}\end{array}$ & $3 \times 10^{-7} \mathrm{M}$ & Not studied & Negligible influence & $\begin{array}{l}\text { DMSO/HEPES solution( } 3: 1, v / v, 1 \\
\mathrm{mM}, \mathrm{pH} 7.2)\end{array}$ & Functionalized with a pyrrole moiety & [215] \\
\hline $\mathrm{Pb}^{2+}, \mathrm{Cu}^{2+}$ & $\begin{array}{l}\text { styrylcyanine dye } \\
\text { containing pyridine }\end{array}$ & $\begin{array}{c}\mathrm{Pb}^{2+}: 3 \times 10^{-5} \text { to } 6 \times \\
10^{-4} \mathrm{M} \\
\mathrm{Cu}^{2+}: 3 \times 10^{-6} \text { to } 9 \times \\
10^{-7} \mathrm{M}\end{array}$ & $\begin{array}{l}\mathrm{Pb}^{2+}: 3.41 \times 10^{-6} \mathrm{M} \\
\mathrm{Cu}^{2+}: 1.24 \times 10^{-6} \mathrm{M}\end{array}$ & Not studied & Negligible influence & $\mathrm{CH}_{3} \mathrm{CN}$-water mixture $(9: 1, v / v)$ & & {$[216]$} \\
\hline
\end{tabular}


Table 6. Cont.

\begin{tabular}{|c|c|c|c|c|c|c|c|c|}
\hline Analyte & Organic Dye & Detection Range & LOD & Reversibility & $\begin{array}{c}\text { Interferent } \\
\text { Analytes }\end{array}$ & Aqueous Media & Observations & Ref. \\
\hline $\mathrm{Zn}^{2+}$ & $\begin{array}{c}\text { Fluorescein-coumarin } \\
\text { conjugate }\end{array}$ & 0 to $1 \times 10^{-5} \mathrm{M}$ & $1 \times 10^{-7} \mathrm{M}$ & Yes & Negligible influence & $\begin{array}{c}\text { HEPES buffer (water/ethanol, 1:9, } \\
v / v ; 10 \text { mM HEPES; pH 7.4) }\end{array}$ & & [217] \\
\hline $\mathrm{Cd}^{2+}$ & coumarin & 0 to $1.6 \times 10^{-5} \mathrm{M}$ & - & Not studied & $\mathrm{Hg}^{2+}$ & Deionized water & $\begin{array}{l}\text { Functionalized with a dipicolylamine } \\
\text { receptor }\end{array}$ & [177] \\
\hline $\mathrm{Ag}^{+}$ & Fluorescein & $\begin{array}{c}\text { L1: } 0 \text { to } 1.98 \times 10^{-6} \\
\mathrm{M} \\
\text { L2: } 0 \text { to } 4.95 \times 10^{-6} \\
\mathrm{M}\end{array}$ & $\begin{array}{l}\text { L1: } 4 \times 10^{-9} \mathrm{M} \\
\text { L2: } 3 \times 10^{-8} \mathrm{M}\end{array}$ & Yes $\left(\mathrm{Na}_{2} \mathrm{~S}\right)$ & Negligible influence & Ethanol & $\begin{array}{l}\text { L1: functionalized with N,S- receptor } \\
\text { L2: functionalized with N,Se- receptor }\end{array}$ & [191] \\
\hline $\mathrm{Pd}^{2+} \mathrm{r}-\mathrm{r}$ & Coumarin 460 & 0 to $1 \times 10^{-5} \mathrm{M}$ & $2.5 \times 10^{-7} \mathrm{M}$ & Not studied & Negligible influence & PBS buffer containing $1 \%$ DMSO & & [218] \\
\hline
\end{tabular}




\section{Comparison between Fluorescent Sensors for Heavy Metal Ions Based on Different Materials}

Although this review is focused on those sensors fabricated with fluorescent aptamers, quantum dots, and organic dyes, other materials can be utilized for the detection of heavy metal ions, such as porphyrins and metal-organic frameworks (MOFs). Thus, in this section, a brief comparison between all the materials is carried out.

As it can be observed in Table 7, the sensors developed with fluorescent aptamers and quantum dots present the lowest limits of detection, oppositely to those fabricated with MOFs. Regarding the detection ranges, the sensors based on porphyrins and MOFs are capable of detecting heavy metal ions at higher concentration ranges (from nanomolar to hundreds of micromolar concentrations) than the rest of the sensors, which monitor concentrations from the picomolar range to the micromolar one. Although reversibility and specificity are not always analyzed, the obtained results are usually positive: the sensors recover their original fluorescence intensity once the contaminants are removed from the aqueous media, and the sensors are not or slightly affected by the presence of other heavy metal ions. 
Table 7. Fluorescent sensors for heavy metal ions based on different kind of materials.

\begin{tabular}{|c|c|c|c|c|c|c|c|}
\hline Type of Material & Sensitive Material & Analyte & Detection Range & LOD & Reversibility & Interferent Analytes & Ref. \\
\hline \multirow[t]{3}{*}{$\begin{array}{l}\text { Fluorophore- } \\
\text { labelled aptamer }\end{array}$} & $\begin{array}{c}\mathrm{Mn}^{2+} \text {-doped } \mathrm{NaYF}_{4}: \mathrm{Yb} \text {, Er UCNPs labelled to } \\
\text { 5'-NH }^{\prime} \text {-TCATCGTTCTTTCTTCCCCTTGTTTGTT-3' } \\
\text { Texas Red labelled to 5'-SH-3 }\left(\mathrm{CH}_{2} \mathrm{CH}_{2} \mathrm{O}\right)_{6^{-}}\end{array}$ & $\mathrm{Hg}^{2+}$ & $5 \times 10^{-8}$ to $5 \times 10^{-7} \mathrm{M}$ & $1.5 \times 10^{-10} \mathrm{M}$ & $91.4-102.3 \%$ & Negligible influence & [82] \\
\hline & $\begin{array}{c}\text { TCATGTTTGTTTGTTGGCCCCCCTTCTTTCTTA-3' } \\
\text { linked to the AuNPs }\end{array}$ & $\mathrm{Hg}^{2+}$ & $1 \times 10^{-11}$ to $1 \times 10^{-6} \mathrm{M}$ & $5.1 \times 10^{-11} \mathrm{M}$ & Not studied & Negligible influence & [64] \\
\hline & $\begin{array}{c}5^{\prime}-\mathrm{Cy} 5.5-\mathrm{SH}-3\left(\mathrm{CH}_{2} \mathrm{CH}_{2} \mathrm{O}\right)_{6}-\mathrm{GGAAGGTGTGGAAGG-3}{ }^{\prime} \\
\text { linked to the Au NPs }\end{array}$ & $\mathrm{Pb}^{2+}$ & $1 \times 10^{-11}$ to $1 \times 10^{-6} \mathrm{M}$ & $2.7 \times 10^{-13} \mathrm{M}$ & Not studied & Negligible influence & [64] \\
\hline \multirow{3}{*}{ Quantum dots } & S- and O- doped carbon nitride QDs & $\mathrm{Hg}^{2+}$ & $1 \times 10^{-8}$ to $1 \times 10^{-6} \mathrm{M}$ & $1 \times 10^{-11} \mathrm{M}$ & Not studied & Negligible influence & [150] \\
\hline & Flavonoid moiety-incorporated carbon QDs & $\mathrm{Pb}^{2+}$ & $1 \times 10^{-10}$ to $2 \times 10^{-8} \mathrm{M}$ & $5.5 \times 10^{-11} \mathrm{M}$ & Not studied & Negligible influence & [157] \\
\hline & Polyethylene glycol capped ZnO QDs (PEG@ZnO QDs) & $\mathrm{Cu}^{2+}$ & $4 \times 10^{-9}$ to $1 \times 10^{-5} \mathrm{M}$ & $3.33 \times 10^{-9} \mathrm{M}$ & $99.6-104 \%$ & Negligible influence & [114] \\
\hline \multirow[t]{2}{*}{ Organic dyes } & 6,7-dihydroxy-3-(3-chlorophenyl) coumarin & $\mathrm{Cu}^{2+}$ & 0 to $2.5 \times 10^{-6} \mathrm{M}$ & $3.3 \times 10^{-10} \mathrm{M}$ & $\begin{array}{c}\text { Yes } \\
\text { (with S }{ }^{2-} \text { ) }\end{array}$ & Negligible influence & [214] \\
\hline & Rhodamine $6 \mathrm{G}$ derivative & $\mathrm{Pb}^{2+}$ & $1 \times 10^{-8}$ to $1 \times 10^{-5} \mathrm{M}$ & $2.7 \times 10^{-9} \mathrm{M}$ & Yes & Negligible influence & [190] \\
\hline \multirow{3}{*}{ Porphyrins } & 5,10,15,20-tetrakis (4-sulfonatophenyl)porphyrin(TPPS) & $\mathrm{Hg}^{2+}$ & $3.3 \times 10^{-8}$ to $3.3 \times 10^{-5} \mathrm{M}$ & $3.3 \times 10^{-8} \mathrm{M}$ & Not studied & Negligible influence & [32] \\
\hline & $\begin{array}{c}\text { 5,10,15,20-tetrakis ( } N \text {-methyl-4-pyridyl) porphyrin } \\
\text { (TMPyP) }\end{array}$ & $\mathrm{Hg}^{2+}$ & $5 \times 10^{-9}$ to $1 \times 10^{-7} \mathrm{M}$ & $1.3 \times 10^{-9} \mathrm{M}$ & $96-105 \%$ & Slightly affected by $\mathrm{Pb}^{2+}$ & [219] \\
\hline & 5,10-bis(4-aminophenyl)-15,20-diphenyl-porphyrin (BATP) & $\mathrm{Cd}^{2+}$ & $5 \times 10^{-8}$ to $4 \times 10^{-6} \mathrm{M}$ & $3.2 \times 10^{-8} \mathrm{M}$ & Yes & $\begin{array}{l}\text { Slightly affected by } \mathrm{Cu}^{2+} \\
\text { and } \mathrm{Hg}^{2+}\end{array}$ & [220] \\
\hline \multirow{3}{*}{$\begin{array}{l}\text { Metal-organic } \\
\text { frameworks }\end{array}$} & UiO-66-PSM & $\mathrm{Hg}^{2+}$ & 0 to $7.81 \times 10^{-5} \mathrm{M}$ & $5.88 \times 10^{-6} \mathrm{M}$ & $96.9-100.6 \%$ & Negligible influence & [221] \\
\hline & MIL-53(Al) & $\mathrm{Fe}^{3+}$ & $3 \times 10^{-6}$ to $2 \times 10^{-4} \mathrm{M}$ & $9 \times 10^{-5} \mathrm{M}$ & $98-106 \%$ & Negligible influence & [222] \\
\hline & UiO-66- $\mathrm{NH}_{2}$ & $\mathrm{Cd}^{2+}$ & $1 \times 10^{-5}$ to $5 \times 10^{-4} \mathrm{M}$ & $3.36 \times 10^{-7} \mathrm{M}$ & Not studied & Not studied & [223] \\
\hline
\end{tabular}




\section{Conclusions}

As it has been shown in this review, fluorescence-based sensors exhibit interesting features for the monitoring of heavy metal ions in aqueous media: the devices presented here exhibit good sensitivity and selectivity, low detection limits as well as large detection ranges. Apart from that, some of them show recovery values close to the $100 \%$, even after being tested in real water samples. Among the heavy metal ion species, special attention has been paid to the sensors devoted to $\mathrm{Hg}^{2+}$, as long as it is one of the most hazardous water pollutants and it presents an accumulative effect on human body through the food chain.

Depending on the application, different sensing materials can be utilized for the monitoring of heavy metal ions: on one side, the utilization of aptamers allows the development of sensors with low detection limits, good reversibility and outstanding specificity for $\mathrm{Hg}^{2+}$ or $\mathrm{Pb}^{2+}$, due to the high affinity that $\mathrm{T}$ and $\mathrm{G}$ bases present for these contaminants, respectively. Additionally, thanks to the functionalization of quantum dots, it is possible to fabricate sensors for monitoring a wide range of heavy metal ions: although their detection limits are not as low as those of the aptasensors, they present good selectivity and reversibility. Finally, the modification of organic dyes with ion recognition units also permits the detection of several metal ions in real water samples, presenting large detection ranges, good selectivity and reversibility. Although the three kinds of materials present appropriate features for sensing applications (low detection limits, acceptable selectivity and reversibility), those devices based on aptamers exhibit the lowest limits of detection and the highest selectivity, due to the high affinity of the T-rich and G-rich ODN sequences for $\mathrm{Hg}^{2+}$ and $\mathrm{Pb}^{2+}$, respectively. However, this specificity for these analytes does not allow their utilization for the detection of other metal ions, which can be done by QDs and organic dyes.

These facts, together with all the advantages that the optic technology presents nowadays, make custom-designed fluorescent sensors attractive tools for the monitoring of heavy metal ions in real applications.

Author Contributions: All authors contributed equally to this work.

Funding: This work was supported by the Spanish State Research Agency (AEI) and the Spanish Ministry of Economy and Competitiveness through the TEC2016-79367-C2-2-R project. Nerea de Acha would also like to acknowledge her pre-doctoral fellowship (reference BES-2014-069692) funded by the Spanish Ministry of Economy and Competitiveness through the TEC2013-43679-R project.

Conflicts of Interest: The authors declare no conflict of interest.

\section{References}

1. World Health Organization. Guidelines for Drinking-Water Quality; World Health Organization: Geneva, Switzerland, 2017.

2. Schriks, M.; Heringa, M.B.; van der Kooi, M.M.E.; de Voogt, P.; van Wezel, A.P. Toxicological relevance of emerging contaminants for drinking water quality. Water Res. 2010, 44, 461-476. [CrossRef] [PubMed]

3. Gregory, M.R. Environmental implications of plastic debris in marine settings- entanglement, ingestion, smothering, hangers-on, hitch-hiking and alien invasions. Philos. Trans. R. Soc. B Biol. Sci. 2009, 364, 2013-2025. [CrossRef] [PubMed]

4. Lockhart, K.M.; King, A.M.; Harter, T. Identifying sources of groundwater nitrate contamination in a large alluvial groundwater basin with highly diversified intensive agricultural production. J. Contam. Hydrol. 2013, 151, 140-154. [CrossRef] [PubMed]

5. Bernstein, N. Contamination of soils with microbial pathogens originating from effluent water used for irrigation. In Proceedings of the EGU General Assembly 2009, Vienna, Austria, 19-24 April 2009.

6. Järup, L. Hazards of heavy metal contamination. Br. Med. Bull. 2003, 68, 167-182. [CrossRef] [PubMed]

7. Goldhaber, S.B. Trace element risk assessment: Essentiality vs. toxicity. Regul. Toxicol. Pharmacol. 2003, 38, 232-242. [CrossRef] 
8. Xie, W.; Peng, C.; Wang, H.; Chen, W. Health risk assessment of trace metals in various environmental media, crops and human hair from a mining affected area. Int. J. Environ. Res. Public Health 2017, 14, 1595. [CrossRef]

9. Stankovic, S.; Jovic, M.; Stankovic, A.R.; Katsikas, L. Heavy Metals in Seafood Mussels. Risks for Human Health; Springer: Dordrecht, The Netherlands, 2012; Volume 1, ISBN 9789400724396.

10. Huff, J.; Lunn, R.M.; Waalkes, M.P.; Tomatis, L.; Infante, P.F. Cadmium-induced cancers in animals and in humans. Int. J. Occup. Environ. Health 2007, 13, 202-212. [CrossRef]

11. Bhatti, P.; Stewart, P.A.; Hutchinson, A.; Rothman, N.; Linet, M.S.; Inskip, P.D.; Rajaraman, P. Lead exposure, polymorphisms in genes related to oxidative stress, and risk of adult brain tumors. Cancer Epidemiol. Biomark. Prev. 2009, 18, 1841-1848. [CrossRef]

12. Bansod, B.; Kumar, T.; Thakur, R.; Rana, S.; Singh, I. A review on various electrochemical techniques for heavy metal ions detection with different sensing platforms. Biosens. Bioelectron. 2017, 94, 443-455. [CrossRef]

13. Jaishankar, M.; Tseten, T.; Anbalagan, N.; Mathew, B.B.; Beeregowda, K.N. Toxicity, mechanism and health effects of some heavy metals. Interdiscip. Toxicol. 2014, 7, 60-72. [CrossRef]

14. Jan, A.T.; Azam, M.; Siddiqui, K.; Ali, A.; Choi, I.; Haq, Q.M.R. Heavy metals and human health: Mechanistic insight into toxicity and counter defense system of antioxidants. Int. J. Mol. Sci. 2015, 16, 29592-29630. [CrossRef] [PubMed]

15. Senthil Kumar, P.; Saravanan, A. Sustainable wastewater treatments in textile sector. Sustain. Fibres Text. 2017, 323-346.

16. Suszcynsky, E.M.; Shann, J.R. Phytotoxicity and accumulation of mercury in tobacco subjected to different exposure routes. Environ. Toxicol. Chem. 1995, 14, 61-67. [CrossRef]

17. Lough, G.C.; Schauer, J.J.; Park, J.-S.; Shafer, M.M.; Deminter, J.T.; Weinstein, J.P. Emissions of metals associated with motor vehicle roadways. Environ. Sci. Technol. 2005, 39, 826-836. [CrossRef] [PubMed]

18. Yuliusman, S.; Nurqomariah, A.; Fajaryanto, R. Recovery of cobalt and nickel from spent lithium ion batteries with citric acid using leaching process: Kinetics study. In Proceedings of the E3S Web of Conferences, Berdyansk, Ukraine, 4-8 September 2018; Volume 67.

19. Arruti, A.; Fernández-Olmo, I.; Irabien, A. Evaluation of the contribution of local sources to trace metals levels in urban PM2.5 and PM10 in the Cantabria region (Northern Spain). J. Environ. Monit. 2010, 12, 1451-1458. [CrossRef] [PubMed]

20. Farzin, L.; Shamsipur, M.; Sheibani, S. A review: Aptamer-based analytical strategies using the nanomaterials for environmental and human monitoring of toxic heavy metals. Talanta 2017, 174, 619-627. [CrossRef] [PubMed]

21. Ye, B.-C.; Yin, B.-C. Highly sensitive detection of mercury(II) ions by fluorescence polarization enhanced by gold nanoparticles. Angew. Chem. Int. Ed. 2008, 47, 8386-8389. [CrossRef]

22. Nolan, E.M.; Lippard, S.J. A “Turn-on” Fluorescent Sensor for the Selective Detection of Mercuric Ion in Aqueous Media. J. Am. Chem. Soc. 2003, 125, 14270-14271. [CrossRef]

23. Simões Da Costa, A.M.; Delgadillo, I.; Rudnitskaya, A. Detection of copper, lead, cadmium and iron in wine using electronic tongue sensor system. Talanta 2014, 129, 63-71. [CrossRef]

24. Alizadeh, T.; Ganjali, M.R.; Zare, M. Application of an $\mathrm{Hg}^{2+}$ selective imprinted polymer as a new modifying agent for the preparation of a novel highly selective and sensitive electrochemical sensor for the determination of ultratrace mercury ions. Anal. Chim. Acta 2011, 689, 52-59. [CrossRef]

25. Kim, H.N.; Ren, W.X.; Kim, J.S.; Yoon, J. Fluorescent and colorimetric sensors for detection of lead, cadmium, and mercury ions. Chem. Soc. Rev. 2012, 41, 3210-3244. [CrossRef] [PubMed]

26. Kuswandi, B.; Nuriman; Huskens, J.; Verboom, W. Optical sensing systems for microfluidic devices: A review. Anal. Chim. Acta 2007, 601, 141-155. [CrossRef] [PubMed]

27. Aiestaran, P.; Dominguez, V.; Arrue, J.; Zubia, J. A fluorescent linear optical fiber position sensor. Opt. Mater. 2009, 31, 1101-1104. [CrossRef]

28. Vendrell, M.; Zhai, D.; Er, J.C.; Chang, Y.-T. Combinatorial strategies in fluorescent probe development. Chem. Rev. 2012, 112, 4391-4420. [CrossRef] [PubMed]

29. Tan, D.; He, Y.; Xing, X.; Zhao, Y.; Tang, H.; Pang, D. Aptamer functionalized gold nanoparticles based fluorescent probe for the detection of mercury (II) ion in aqueous solution. Talanta 2013, 113, 26-30. [CrossRef] [PubMed] 
30. Lakowicz, J.R. Principles of Fluorescence Spectroscopy; Lakowicz, J.R., Ed.; Springer: Boston, MA, USA, 2006; ISBN 978-0-387-31278-1.

31. Elosua, C.; de Acha, N.; Lopez-Torres, D.; Matias, I.R.; Arregui, F.J. Luminescent Optical Fiber Oxygen Sensor following Layer-by-layer Method. Procedia Eng. 2014, 87, 987-990. [CrossRef]

32. Caselli, M. Porphyrin-based electrostatically self-assembled multilayers as fluorescent probes for mercury(ii) ions: A study of the adsorption kinetics of metal ions on ultrathin films for sensing applications. RSC Adv. 2015, 5, 1350-1358. [CrossRef]

33. Yang, J.; Wang, Z.; Li, Y.; Zhuang, Q.; Zhao, W.; Gu, J. Porphyrinic MOFs for reversible fluorescent and colorimetric sensing of mercury(II) ions in aqueous phase. RSC Adv. 2016, 6, 69807-69814. [CrossRef]

34. He, J.-L.; Zhu, S.-L.; Wu, P.; Li, P.-P.; Li, T.; Cao, Z. Enzymatic cascade based fluorescent DNAzyme machines for the ultrasensitive detection of $\mathrm{Cu}(\mathrm{II})$ ions. Biosens. Bioelectron. 2014, 60, 112-117. [CrossRef]

35. Zhu, Y.-F.; Wang, Y.-S.; Zhou, B.; Yu, J.-H.; Peng, L.-L.; Huang, Y.-Q.; Li, X.-J.; Chen, S.-H.; Tang, X.; Wang, X.-F. A multifunctional fluorescent aptamer probe for highly sensitive and selective detection of cadmium(II). Anal. Bioanal. Chem. 2017, 409, 4951-4958. [CrossRef]

36. Xu, H.; Miao, R.; Fang, Z.; Zhong, X. Quantum dot-based turn-on fluorescent probe for detection of zinc and cadmium ions in aqueous media. Anal. Chim. Acta 2011, 687, 82-88. [CrossRef] [PubMed]

37. Cai, S.; Lu, Y.; He, S.; Wei, F.; Zhao, L.; Zeng, X. A highly sensitive and selective turn-on fluorescent chemosensor for palladium based on a phosphine-rhodamine conjugate. Chem. Commun. 2013, 49, 822-824. [CrossRef] [PubMed]

38. Lakhin, A.V.; Tarantul, V.Z.; Gening, L.V. Aptamers: Problems, solutions and prospects. Acta Nat. 2013, 5, 34-43.

39. Lung Khung, Y.; Narducci, D. Synergizing nucleic acid aptamers with 1-dimensional nanostructures as label-free field-effect transistor biosensors. Biosens. Bioelectron. 2013, 50, 278-293. [CrossRef] [PubMed]

40. Bozokalfa, G.; Akbulut, H.; Demir, B.; Guler, E.; Gumus, Z.P.; Odaci Demirkol, D.; Aldemir, E.; Yamada, S.; Endo, T.; Coskunol, H.; et al. Polypeptide Functional Surface for the Aptamer Immobilization: Electrochemical Cocaine Biosensing. Anal. Chem. 2016, 88, 4161-4167. [CrossRef] [PubMed]

41. Kim, Y.S.; Niazi, J.H.; Gu, M.B. Specific detection of oxytetracycline using DNA aptamer-immobilized interdigitated array electrode chip. Anal. Chim. Acta 2009, 634, 250-254. [CrossRef] [PubMed]

42. Radom, F.; Jurek, P.M.; Mazurek, M.P.; Otlewski, J.; Jeleń, F. Aptamers: Molecules of great potential. Biotechnol. Adv. 2013, 31, 1260-1274. [CrossRef]

43. Lassalle, H.-P.; Marchal, S.; Guillemin, F.; Reinhard, A.; Bezdetnaya, L. Aptamers as remarkable diagnostic and therapeutic agents in cancer treatment. Curr. Drug Metab. 2012, 13, 1130-1144. [CrossRef]

44. Zhao, Q.; Zhang, Z.; Xu, L.; Xia, T.; Li, N.; Liu, J.; Fang, X. Exonuclease i aided enzyme-linked aptamer assay for small-molecule detection. Anal. Bioanal. Chem. 2014, 406, 2949-2955. [CrossRef]

45. Jiang, H.; Ling, K.; Tao, X.; Zhang, Q. Theophylline detection in serum using a self-assembling RNA aptamer-based gold nanoparticle sensor. Biosens. Bioelectron. 2015, 70, 299-303. [CrossRef]

46. Liu, Y.; Lai, Y.; Yang, G.; Tang, C.; Deng, Y.; Li, S.; Wang, Z. Cd-aptamer electrochemical biosensor based on AuNPs/CS modified glass carbon electrode. J. Biomed. Nanotechnol. 2017, 13, 1253-1259. [CrossRef]

47. Miyake, Y.; Togashi, H.; Tashiro, M.; Yamaguchi, H.; Oda, S.; Kudo, M.; Tanaka, Y.; Kondo, Y.; Sawa, R.; Fujimoto, T.; et al. Mercury ${ }^{\mathrm{II}}$-mediated formation of thymine- $\mathrm{Hg}^{\mathrm{II}}$-thymine base pairs in DNA duplexes. J. Am. Chem. Soc. 2006, 128, 2172-2173. [CrossRef] [PubMed]

48. Ono, A.; Cao, S.; Togashi, H.; Tashiro, M.; Fujimoto, T.; MacHinami, T.; Oda, S.; Miyake, Y.; Okamoto, I.; Tanaka, Y. Specific interactions between silver(i) ions and cytosine-cytosine pairs in DNA duplexes. Chem. Commun. 2008, 4825-4827. [CrossRef] [PubMed]

49. Ono, A.; Togashi, H. Highly selective oligonucleotide-based sensor for mercury(II) in aqueous solutions. Angew. Chem. Int. Ed. 2004, 43, 4300-4302. [CrossRef] [PubMed]

50. Li, L.; Li, B.; Qi, Y.; Jin, Y. Label-free aptamer-based colorimetric detection of mercury ions in aqueous media using unmodified gold nanoparticles as colorimetric probe. Anal. Bioanal. Chem. 2009, 393, 2051-2057. [CrossRef] [PubMed]

51. Zhang, L.; Chang, H.; Hirata, A.; Wu, H.; Xue, Q.-K.; Chen, M. Nanoporous gold based optical sensor for sub-ppt detection of mercury ions. ACS Nano 2013, 7, 4595-4600. [CrossRef] 
52. Liu, C.-W.; Tsai, T.-C.; Osawa, M.; Chang, H.-C.; Yang, R.-J. Aptamer-based sensor for quantitative detection of mercury (II) ions by attenuated total reflection surface enhanced infrared absorption spectroscopy. Anal. Chim. Acta 2018, 1033, 137-147. [CrossRef]

53. Li, B.; Du, Y.; Dong, S. DNA based gold nanoparticles colorimetric sensors for sensitive and selective detection of Ag(I) ions. Anal. Chim. Acta 2009, 644, 78-82. [CrossRef]

54. Wen, Y.; Xing, F.; He, S.; Song, S.; Wang, L.; Long, Y.; Li, D.; Fan, C. A graphene-based fluorescent nanoprobe for silver(i) ions detection by using graphene oxide and a silver-specific oligonucleotide. Chem. Commun. 2010, 46, 2596-2598. [CrossRef]

55. Park, J.; Choi, W.; Jang, K.; Na, S. High-sensitivity detection of silver ions using oligonucleotide-immobilized oscillator. Biosens. Bioelectron. 2013, 41, 471-476. [CrossRef]

56. Guo, L.; Nie, D.; Qiu, C.; Zheng, Q.; Wu, H.; Ye, P.; Hao, Y.; Fu, F.; Chen, G. A G-quadruplex based label-free fluorescent biosensor for lead ion. Biosens. Bioelectron. 2012, 35, 123-127. [CrossRef] [PubMed]

57. Kim, B.; Jung, I.H.; Kang, M.; Shim, H.-K.; Woo, H.Y. Cationic conjugated polyelectrolytes-triggered conformational change of molecular beacon aptamer for highly sensitive and selective potassium ion detection. J. Am. Chem. Soc. 2012, 134, 3133-3138. [CrossRef] [PubMed]

58. Lin, Z.; Chen, Y.; Li, X.; Fang, W. $\mathrm{Pb}^{2+}$ induced DNA conformational switch from hairpin to G-quadruplex: Electrochemical detection of $\mathrm{Pb}^{2+}$. Analyst 2011, 136, 2367-2372. [CrossRef] [PubMed]

59. Li, F.; Feng, Y.; Zhao, C.; Tang, B. Crystal violet as a G-quadruplex-selective probe for sensitive amperometric sensing of lead. Chem. Commun. 2011, 47, 11909-11911. [CrossRef] [PubMed]

60. Guo, L.; Yin, N.; Chen, G. Photoinduced electron transfer mediated by $\pi$-stacked thymine- $\mathrm{Hg}^{2+}$-thymine base pairs. J. Phys. Chem. C 2011, 115, 4837-4842. [CrossRef]

61. Liu, C.-W.; Huang, C.-C.; Chang, H.-T. Highly selective DNA-based sensor for lead(II) and mercury(II) ions. Anal. Chem. 2009, 81, 2383-2387. [CrossRef]

62. Ono, A. Development of novel oligonucleotide-based sensors which are highly $\mathrm{Hg}(\mathrm{II})$ selective and are insensitive to other heavy metal ions. Nucleic Acids Symp. Ser. (Oxf.) 2004, 29-30. [CrossRef]

63. Wang, Y.; Bao, L.; Liu, Z.; Pang, D.-W. Aptamer biosensor based on fluorescence resonance energy transfer from upconverting phosphors to carbon nanoparticles for thrombin detection in human plasma. Anal. Chem. 2011, 83, 8130-8137. [CrossRef]

64. Chung, C.H.; Kim, J.H.; Jung, J.; Chung, B.H. Nuclease-resistant DNA aptamer on gold nanoparticles for the simultaneous detection of $\mathrm{Pb}^{2+}$ and $\mathrm{Hg}^{2+}$ in human serum. Biosens. Bioelectron. 2013, 41, 827-832. [CrossRef]

65. Chen, S.-H.; Wang, Y.-S.; Chen, Y.-S.; Tang, X.; Cao, J.-X.; Li, M.-H.; Wang, X.-F.; Zhu, Y.-F.; Huang, Y.-Q. Dual-channel detection of metallothioneins and mercury based on a mercury-mediated aptamer beacon using thymidine-mercury-thymidine complex as a quencher. Spectrochim. Acta Part A Mol. Biomol. Spectrosc. 2015, 151, 315-321. [CrossRef]

66. Zeng, X.; Zhang, F.S.; Zhu, B.; Zhu, L. Fluorescence Determination of Merucury(II) Using a Thymine Aptamer. Anal. Lett. 2015, 48, 2208-2216. [CrossRef]

67. Johansson, M.K. Choosing reporter-quencher pairs for efficient quenching through formation of intramolecular dimers. Methods Mol. Biol. 2006, 335, 17-29. [PubMed]

68. Li, Z.; Muhandiramlage, T.P.; Keogh, J.P.; Hall, H.K.; Aspinwall, C.A. Aptamer-functionalized porous phospholipid nanoshells for direct measurement of $\mathrm{Hg}(2+)$ in urine. Anal. Bioanal. Chem. 2015, 407, 953-960. [CrossRef] [PubMed]

69. Fialová, M.; Kypr, J.; Vorlíčková, M. The thrombin binding aptamer GGTTGGTGTGGTTGG forms a bimolecular guanine tetraplex. Biochem. Biophys. Res. Commun. 2006, 344, 50-54. [CrossRef]

70. Huang, X.; Ren, J. Gold nanoparticles based chemiluminescent resonance energy transfer for immunoassay of alpha fetoprotein cancer marker. Anal. Chim. Acta 2011, 686, 115-120. [CrossRef] [PubMed]

71. Mayilo, S.; Kloster, M.A.; Wunderlich, M.; Lutich, A.; Klar, T.A.; Nichtl, A.; Kürzinger, K.; Stefani, F.D.; Feldmann, J. Long-range fluorescence quenching by gold nanoparticles in a sandwich immunoassay for cardiac troponin T. Nano Lett. 2009, 9, 4558-4563. [CrossRef] [PubMed]

72. Xu, X.; Wang, J.; Jiao, K.; Yang, X. Colorimetric detection of mercury ion $\left(\mathrm{Hg}^{2+}\right)$ based on DNA oligonucleotides and unmodified gold nanoparticles sensing system with a tunable detection range. Biosens. Bioelectron. 2009, 24, 3153-3158. [CrossRef] [PubMed] 
73. Huang, D.; Niu, C.; Wang, X.; Lv, X.; Zeng, G. “Turn-on” fluorescent sensor for $\mathrm{Hg}^{2+}$ based on single-stranded DNA functionalized Mn:CdS/ZnS quantum dots and gold nanoparticles by time-gated mode. Anal. Chem. 2013, 85, 1164-1170. [CrossRef] [PubMed]

74. Liu, Y.; Ouyang, Q.; Li, H.; Chen, M.; Zhang, Z.; Chen, Q. Turn-On Fluoresence Sensor for $\mathrm{Hg}^{2+}$ in Food Based on FRET between Aptamers-Functionalized Upconversion Nanoparticles and Gold Nanoparticles. J. Agric. Food Chem. 2018, 66, 6188-6195. [CrossRef]

75. Long, F.; Zhu, A.; Wang, H. Optofluidics-based DNA structure-competitive aptasensor for rapid on-site detection of lead(II) in an aquatic environment. Anal. Chim. Acta 2014, 849, 43-49. [CrossRef] [PubMed]

76. Dragan, A.I.; Casas-Finet, J.R.; Bishop, E.S.; Strouse, R.J.; Schenerman, M.A.; Geddes, C.D. Characterization of PicoGreen interaction with dsDNA and the origin of its fluorescence enhancement upon binding. Biophys. J. 2010, 99, 3010-3019. [CrossRef] [PubMed]

77. Singer, V.L.; Lawlor, T.E.; Yue, S. Comparison of SYBR ${ }^{\circledR}$ Green I nucleic acid gel stain mutagenicity and ethidium bromide mutagenicity in the Salmonella/mammalian microsome reverse mutation assay (Ames test). Mutat. Res. Genet. Toxicol. Environ. Mutagen. 1999, 439, 37-47. [CrossRef]

78. Zhang, J.; Huang, Y.; Yan, J.; Zhu, C.; Zhang, C.; Chen, A. Dulplex analysis of mercury and silver ions using a label-free fluorescent aptasensor. Int. J. Environ. Anal. Chem. 2018, 98, 349-359. [CrossRef]

79. Yan, Z.; Tian, C.; Qu, X.; Shen, W.; Ye, B. DNA-functionalized photonic crystal microspheres for multiplex detection of toxic metal ions. Colloids Surf. B Biointerfaces 2017, 154, 142-149. [CrossRef] [PubMed]

80. Li, M.; Zhou, X.; Ding, W.; Guo, S.; Wu, N. Fluorescent aptamer-functionalized graphene oxide biosensor for label-free detection of mercury(II). Biosens. Bioelectron. 2013, 41, 889-893. [CrossRef]

81. Li, J.; Wang, H.; Guo, Z.; Wang, Y.; Ma, H.; Ren, X.; Du, B.; Wei, Q. A “turn-off” fluorescent biosensor for the detection of mercury (II) based on graphite carbon nitride. Talanta 2017, 162, 46-51. [CrossRef] [PubMed]

82. Wu, S.; Duan, N.; Shi, Z.; Fang, C.; Wang, Z. Dual fluorescence resonance energy transfer assay between tunable upconversion nanoparticles and controlled gold nanoparticles for the simultaneous detection of $\mathrm{Pb}^{2+}$ and $\mathrm{Hg}^{2+}$. Talanta 2014, 128, 327-336. [CrossRef] [PubMed]

83. Huang, D.; Niu, C.; Ruan, M.; Wang, X.; Zeng, G.; Deng, C. Highly sensitive strategy for $\mathrm{Hg}^{2+}$ detection in environmental water samples using long lifetime fluorescence quantum dots and gold nanoparticles. Environ. Sci. Technol. 2013, 47, 4392-4398. [CrossRef] [PubMed]

84. Cui, X.; Zhu, L.; Wu, J.; Hou, Y.; Wang, P.; Wang, Z.; Yang, M. A fluorescent biosensor based on carbon dots-labeled oligodeoxyribonucleotide and graphene oxide for mercury (II) detection. Biosens. Bioelectron. 2015, 63, 506-512. [CrossRef]

85. Zhang, L.; Mi, N.; Zhang, Y.; Wei, M.; Li, H.; Yao, S. Label-free DNA sensor for $\mathrm{Pb}^{2+}$ based on a duplex-quadruplex exchange. Anal. Methods 2013, 5, 6100-6105. [CrossRef]

86. Huang, Y.; Yan, J.; Fang, Z.; Zhang, C.; Bai, W.; Yan, M.; Zhu, C.; Gao, C.; Chen, A. Highly sensitive and selective optical detection of lead(ii) using a label-free fluorescent aptasensor. RSC Adv. 2016, 6, 90300-90304. [CrossRef]

87. Liu, C.; Huang, C.-Z. Detection of lead ions in water based on the surface energy transfer between gold nanoparticles and fluorescent dyes. Fenxi Huaxue/Chin. J. Anal. Chem. 2014, 42, 1195-1199. [CrossRef]

88. Taghdisi, S.M.; Emrani, S.S.; Tabrizian, K.; Ramezani, M.; Abnous, K.; Emrani, A.S. Ultrasensitive detection of lead (II) based on fluorescent aptamer-functionalized carbon nanotubes. Environ. Toxicol. Pharmacol. 2014, 37, 1236-1242. [CrossRef] [PubMed]

89. Qian, Z.S.; Shan, X.Y.; Chai, L.J.; Chen, J.R.; Feng, H. A fluorescent nanosensor based on graphene quantum dots-aptamer probe and graphene oxide platform for detection of lead (II) ion. Biosens. Bioelectron. 2015, 68, 225-231. [CrossRef] [PubMed]

90. Li, M.; Zhou, X.; Guo, S.; Wu, N. Detection of lead (II) with a "turn-on" fluorescent biosensor based on energy transfer from CdSe/ZnS quantum dots to graphene oxide. Biosens. Bioelectron. 2013, 43, 69-74. [CrossRef] [PubMed]

91. Yan, M.; Zhu, C.; Huang, Y.; Yan, J.; Chen, A. Ultrasensitive detection of lead(II) using a turn-on probe based on the use of an aptamer and a water-soluble fluorescent perylene probe. Microchim. Acta 2017, 184, 2439-2444. [CrossRef]

92. Niu, X.; Zhong, Y.; Chen, R.; Wang, F.; Liu, Y.; Luo, D. A “turn-on" fluorescence sensor for Pb ${ }^{2+}$ detection based on graphene quantum dots and gold nanoparticles. Sens. Actuators B Chem. 2018, 255, 1577-1581. [CrossRef] 
93. Frasco, M.F.; Chaniotakis, N. Semiconductor quantum dots in chemical sensors and biosensors. Sensors 2009, 9, 7266-7286. [CrossRef]

94. Bera, D.; Qian, L.; Tseng, T.-K.; Holloway, P.H. Quantum dots and their multimodal applications: A review. Materials (Basel) 2010, 3, 2260-2345. [CrossRef]

95. Hardman, R. A toxicologic review of quantum dots: Toxicity depends on physicochemical and environmental factors. Environ. Health Perspect. 2006, 114, 165-172. [CrossRef]

96. Renugopalakrishnan, V.; Barbiellini, B.; King, C.; Molinari, M.; Mochalov, K.; Sukhanova, A.; Nabiev, I.; Fojan, P.; Tuller, H.L.; Chin, M.; et al. Engineering a robust photovoltaic device with quantum dots and bacteriorhodopsin. J. Phys. Chem. C 2014, 118, 16710-16717. [CrossRef] [PubMed]

97. Jang, E.; Jun, S.; Jang, H.; Lim, J.; Kim, B.; Kim, Y. White-light-emitting diodes with quantum dot color converters for display backlights. Adv. Mater. 2010, 22, 3076-3080. [CrossRef] [PubMed]

98. Wu, F.; Su, H.; Wang, K.; Wong, W.-K.; Zhu, X. Facile synthesis of N-rich carbon quantum dots from porphyrins as efficient probes for bioimaging and biosensing in living cells. Int. J. Nanomed. 2017, 12, 7375-7391. [CrossRef] [PubMed]

99. Lv, S.; Chen, F.; Chen, C.; Chen, X.; Gong, H.; Cai, C. A novel CdTe quantum dots probe amplified resonance light scattering signals to detect microRNA-122. Talanta 2017, 165, 659-663. [CrossRef] [PubMed]

100. Carrillo-Carrión, C.; Simonet, B.M.; Valcárcel, M. Colistin-functionalised CdSe/ZnS quantum dots as fluorescent probe for the rapid detection of Escherichia coli. Biosens. Bioelectron. 2011, 26, 4368-4374. [CrossRef] [PubMed]

101. Sidorov, A.I.; Lebedev, V.F.; Kobranova, A.A.; Nashchekin, A.V. Formation of carbon quantum dots and nanodiamonds in laser ablation of a carbon film. Quantum Electron. 2018, 48, 45-48. [CrossRef]

102. Kelarakis, A. Graphene quantum dots: In the crossroad of graphene, quantum dots and carbogenic nanoparticles. Curr. Opin. Colloid Interface Sci. 2015, 20, 354-361. [CrossRef]

103. Guo, Y.; Zhang, L.; Zhang, S.; Yang, Y.; Chen, X.; Zhang, M. Fluorescent carbon nanoparticles for the fluorescent detection of metal ions. Biosens. Bioelectron. 2015, 63, 61-71. [CrossRef]

104. Cai, J.; Sun, B.; Gou, X.; Gou, Y.; Li, W.; Hu, F. A novel way for analysis of calycosin via polyaniline functionalized graphene quantum dots fabricated electrochemical sensor. J. Electroanal. Chem. 2018, 816, 123-131. [CrossRef]

105. Constantine, C.A.; Gattás-Asfura, K.M.; Mello, S.V.; Crespo, G.; Rastogi, V.; Cheng, T.-C.; DeFrank, J.J.; Leblanc, R.M. Layer-by-layer biosensor assembly incorporating functionalized quantum dots. Langmuir 2003, 19, 9863-9867. [CrossRef]

106. Lin, X.; Gao, G.; Zheng, L.; Chi, Y.; Chen, G. Encapsulation of strongly fluorescent carbon quantum dots in metal-organic frameworks for enhancing chemical sensing. Anal. Chem. 2014, 86, 1223-1228. [CrossRef] [PubMed]

107. Ding, X.; Qu, L.; Yang, R.; Zhou, Y.; Li, J. A highly selective and simple fluorescent sensor for mercury (II) ion detection based on cysteamine-capped CdTe quantum dots synthesized by the reflux method. Luminescence 2015, 30, 465-471. [CrossRef] [PubMed]

108. Zhou, M.; Guo, J.; Yang, C. Ratiometric fluorescence sensor for $\mathrm{Fe}^{3+}$ ions detection based on quantum dot-doped hydrogel optical fiber. Sens. Actuators B Chem. 2018, 264, 52-58. [CrossRef]

109. Labeb, M.; Sakr, A.-H.; Soliman, M.; Abdel-Fettah, T.M.; Ebrahim, S. Effect of capping agent on selectivity and sensitivity of CdTe quantum dots optical sensor for detection of mercury ions. Opt. Mater. (Amst.) 2018, 79, 331-335. [CrossRef]

110. Gong, T.; Liu, J.; Liu, X.; Liu, J.; Xiang, J.; Wu, Y. A sensitive and selective sensing platform based on CdTe QDs in the presence of L-cysteine for detection of silver, mercury and copper ions in water and various drinks. Food Chem. 2016, 213, 306-312. [CrossRef] [PubMed]

111. Xu, L.; Hao, J.; Yi, T.; Xu, Y.; Niu, X.; Ren, C.; Chen, H.; Chen, X. Probing the mechanism of the interaction between l-cysteine-capped-CdTe quantum dots and $\mathrm{Hg}^{2+}$ using capillary electrophoresis with ensemble techniques. Electrophoresis 2015, 36, 859-866. [CrossRef] [PubMed]

112. Fan, Y.; Cai, Y.-Q.; Liu, H.-J.; Chen, Y. CdS quantum dots capped with hyperbranched graft copolymers: Role of hyperbranched shell in fluorescence and selective mercury-sensing. Sens. Actuators B Chem. 2017, 251, 171-179. [CrossRef]

113. Chen, G.-F.; Tsai, H.-P.; Lai, P.-S.; Liao, M.-Y. Functionalized $\mathrm{Mn}^{2+}$-doped zinc sulfide quantum dots as a metal ion sensor for industrial wastes. Sens. Mater. 2013, 25, 437-442. [CrossRef] 
114. Geng, S.; Lin, S.M.; Li, N.B.; Luo, H.Q. Polyethylene glycol capped ZnO quantum dots as a fluorescent probe for determining copper(II) ion. Sens. Actuators B Chem. 2017, 253, 137-143. [CrossRef]

115. Rezaei, B.; Shahshahanipour, M.; Ensafi, A.A.; Farrokhpour, H. Development of highly selective and sensitive fluorimetric label-free mercury aptasensor based on cysteamine@CdTe/ZnS quantum dots, experimental and theoretical investigation. Sens. Actuators B Chem. 2017, 247, 400-407. [CrossRef]

116. Xi, L.-L.; Ma, H.-B.; Tao, G.-H. Thiourea functionalized CdSe/CdS quantum dots as a fluorescent sensor for mercury ion detection. Chin. Chem. Lett. 2016, 27, 1531-1536. [CrossRef]

117. Xu, X.; Ray, R.; Gu, Y.; Ploehn, H.J.; Gearheart, L.; Raker, K.; Scrivens, W.A. Electrophoretic analysis and purification of fluorescent single-walled carbon nanotube fragments. J. Am. Chem. Soc. 2004, 126, 12736-12737. [CrossRef] [PubMed]

118. Esteves da Silva, J.C.G.; Gonçalves, H.M.R. Analytical and bioanalytical applications of carbon dots. TrAC Trends Anal. Chem. 2011, 30, 1327-1336. [CrossRef]

119. Baker, S.N.; Baker, G.A. Luminescent carbon nanodots: Emergent nanolights. Angew. Chem. Int. Ed. 2010, 49, 6726-6744. [CrossRef] [PubMed]

120. Sun, X.; Lei, Y. Fluorescent carbon dots and their sensing applications. TrAC Trends Anal. Chem. 2017, 89, 163-180. [CrossRef]

121. Shi, Y.; Li, C.; Liu, S.; Liu, Z.; Zhu, J.; Yang, J.; Hu, X. Facile synthesis of fluorescent carbon dots for determination of curcumin based on fluorescence resonance energy transfer. RSC Adv. 2015, 5, 64790-64796. [CrossRef]

122. Lin, L.; Luo, Y.; Tsai, P.; Wang, J.; Chen, X. Metal ions doped carbon quantum dots: Synthesis, physicochemical properties, and their applications. TrAC Trends Anal. Chem. 2018, 103, 87-101. [CrossRef]

123. Wang, H.; Sun, P.; Cong, S.; Wu, J.; Gao, L.; Wang, Y.; Dai, X.; Yi, Q.; Zou, G. Nitrogen-doped carbon dots for "green" quantum dot solar cells. Nanoscale Res. Lett. 2016, 11, 27. [CrossRef]

124. Barati, A.; Shamsipur, M.; Arkan, E.; Hosseinzadeh, L.; Abdollahi, H. Synthesis of biocompatible and highly photoluminescent nitrogen doped carbon dots from lime: Analytical applications and optimization using response surface methodology. Mater. Sci. Eng. C 2015, 47, 325-332. [CrossRef]

125. Wang, C.; Hu, T.; Wen, Z.; Zhou, J.; Wang, X.; Wu, Q.; Wang, C. Concentration-dependent color tunability of nitrogen-doped carbon dots and their application for iron(III) detection and multicolor bioimaging. J. Colloid Interface Sci. 2018, 521, 33-41. [CrossRef]

126. Xiao, N.; Liu, S.G.; Mo, S.; Li, N.; Ju, Y.J.; Ling, Y.; Li, N.B.; Luo, H.Q. Highly selective detection of p-nitrophenol using fluorescence assay based on boron, nitrogen co-doped carbon dots. Talanta 2018, 184, 184-192. [CrossRef] [PubMed]

127. Chen, J.; Liu, J.; Li, J.; Xu, L.; Qiao, Y. One-pot synthesis of nitrogen and sulfur co-doped carbon dots and its application for sensor and multicolor cellular imaging. J. Colloid Interface Sci. 2017, 485, 167-174. [CrossRef]

128. Zhi, B.; Gallagher, M.J.; Frank, B.P.; Lyons, T.Y.; Qiu, T.A.; Da, J.; Mensch, A.C.; Hamers, R.J.; Rosenzweig, Z.; Fairbrother, D.H.; et al. Investigation of phosphorous doping effects on polymeric carbon dots: Fluorescence, photostability, and environmental impact. Carbon N. Y. 2018, 129, 438-449. [CrossRef]

129. Liu, Y.; Liao, M.; He, X.; Liu, X.; Kou, X.; Xiao, D. One-step synthesis of highly luminescent nitrogen-doped carbon dots for selective and sensitive detection of mercury(ii) ions and cellular imaging. Anal. Sci. 2015, 31, 971-977. [CrossRef] [PubMed]

130. Zhang, H.; Chen, Y.; Liang, M.; Xu, L.; Qi, S.; Chen, H.; Chen, X. Solid-phase synthesis of highly fluorescent nitrogen-doped carbon dots for sensitive and selective probing ferric ions in living cells. Anal. Chem. 2014, 86, 9846-9852. [CrossRef] [PubMed]

131. Li, S.; Li, Y.; Cao, J.; Zhu, J.; Fan, L.; Li, X. Sulfur-doped graphene quantum dots as a novel fluorescent probe for highly selective and sensitive detection of $\mathrm{Fe}^{3+}$. Anal. Chem. 2014, 86, 10201-10207. [CrossRef] [PubMed]

132. Xu, Q.; Pu, P.; Zhao, J.; Dong, C.; Gao, C.; Chen, Y.; Chen, J.; Liu, Y.; Zhou, H. Preparation of highly photoluminescent sulfur-doped carbon dots for Fe(iii) detection. J. Mater. Chem. A 2015, 3, 542-546. [CrossRef]

133. Wu, F.; Yang, M.; Zhang, H.; Zhu, S.; Zhu, X.; Wang, K. Facile synthesis of sulfur-doped carbon quantum dots from vitamin B1 for highly selective detection of $\mathrm{Fe}^{3+}$ ion. Opt. Mater. (Amst.) 2018, 77, 258-263. [CrossRef]

134. Naik, V.M.; Gunjal, D.B.; Gore, A.H.; Pawar, S.P.; Mahanwar, S.T.; Anbhule, P.V.; Kolekar, G.B. Quick and low cost synthesis of sulphur doped carbon dots by simple acidic carbonization of sucrose for the detection of $\mathrm{Fe}^{3+}$ ions in highly acidic environment. Diam. Relat. Mater. 2018, 88, 262-268. [CrossRef] 
135. Yang, G.; Wan, X.; Su, Y.; Zeng, X.; Tang, J. Acidophilic S-doped carbon quantum dots derived from cellulose fibers and their fluorescence sensing performance for metal ions in an extremely strong acid environment. J. Mater. Chem. A 2016, 4, 12841-12849. [CrossRef]

136. Wang, Y.; Kim, S.-H.; Feng, L. Highly luminescent N, S- Co-doped carbon dots and their direct use as mercury(II) sensor. Anal. Chim. Acta 2015, 890, 134-142. [CrossRef]

137. Sun, H.; Wu, L.; Wei, W.; Qu, X. Recent advances in graphene quantum dots for sensing. Mater. Today 2013, 16, 433-442. [CrossRef]

138. Shi, B.; Zhang, L.; Lan, C.; Zhao, J.; Su, Y.; Zhao, S. One-pot green synthesis of oxygen-rich nitrogen-doped graphene quantum dots and their potential application in $\mathrm{pH}$-sensitive photoluminescence and detection of mercury(II) ions. Talanta 2015, 142, 131-139. [CrossRef]

139. Bian, S.; Shen, C.; Hua, H.; Zhou, L.; Zhu, H.; Xi, F.; Liu, J.; Dong, X. One-pot synthesis of sulfur-doped graphene quantum dots as a novel fluorescent probe for highly selective and sensitive detection of lead(II). RSC Adv. 2016, 6, 69977-69983. [CrossRef]

140. Anh, N.T.N.; Chowdhury, A.D.; Doong, R. Highly sensitive and selective detection of mercury ions using N, S-codoped graphene quantum dots and its paper strip based sensing application in wastewater. Sens. Actuators B Chem. 2017, 252, 1169-1178. [CrossRef]

141. Zhu, J.; Chang, H.; Li, J.-J.; Li, X.; Zhao, J.-W. Using silicon-coated gold nanoparticles to enhance the fluorescence of CdTe quantum dot and improve the sensing ability of mercury (II). Spectrochim. Acta Part A Mol. Biomol. Spectrosc. 2018, 188, 170-178. [CrossRef]

142. Wan, X.; Li, S.; Zhuang, L.; Tang, J. 1-Tryptophan-capped carbon quantum dots for the sensitive and selective fluorescence detection of mercury ion in aqueous solution. J. Nanoparticle Res. 2016, 18, 202. [CrossRef]

143. Ke, J.; Li, X.; Zhao, Q.; Hou, Y.; Chen, J. Ultrasensitive quantum dot fluorescence quenching assay for selective detection of mercury ions in drinking water. Sci. Rep. 2014, 4, 5624. [CrossRef]

144. Yang, R.; Ding, X.; Zhou, Y.; Li, J.; Qu, L.; Zhang, K. A novel fluorescent sensor for mercury (ii) ion using self-assembly of poly(diallyl dimethyl ammonium)chloride functionalized CdTe quantum dots. Anal. Methods 2015, 7, 436-442. [CrossRef]

145. Hua, M.; Wang, C.; Qian, J.; Wang, K.; Yang, Z.; Liu, Q.; Mao, H.; Wang, K. Preparation of graphene quantum dots based core-satellite hybrid spheres and their use as the ratiometric fluorescence probe for visual determination of mercury(II) ions. Anal. Chim. Acta 2015, 888, 173-181. [CrossRef]

146. Fu, H.; Ji, Z.; Chen, X.; Cheng, A.; Liu, S.; Gong, P.; Li, G.; Chen, G.; Sun, Z.; Zhao, X.; et al. A versatile ratiometric nanosensing approach for sensitive and accurate detection of $\mathrm{Hg}^{2+}$ and biological thiols based on new fluorescent carbon quantum dots. Anal. Bioanal. Chem. 2017, 409, 2373-2382. [CrossRef]

147. Sun, X.; Yang, S.; Guo, M.; Ma, S.; Zheng, M.; He, J. Reversible fluorescence probe based on N-doped carbon dots for the determination of mercury ion and glutathione in waters and living cells. Anal. Sci. 2017, 33, 761-767. [CrossRef]

148. Zhang, R.; Chen, W. Nitrogen-doped carbon quantum dots: Facile synthesis and application as a "turn-off" fluorescent probe for detection of $\mathrm{Hg}^{2+}$ ions. Biosens. Bioelectron. 2013, 55, 83-90. [CrossRef]

149. Li, L.-L.; Ni, G.; Wang, J.-N.; Li, J.; Li, W. Synthesis of nitrogen-doped carbon quantum dots and its application as fluorescent sensor for $\mathrm{Hg}^{2+}$. Guang Pu Xue Yu Guang Pu Fen Xi/Spectrosc. Spectr. Anal. 2016, 36, 2846-2851.

150. Patir, K.; Gogoi, S.K. Facile Synthesis of Photoluminescent Graphitic Carbon Nitride Quantum Dots for $\mathrm{Hg}^{2+}$ Detection and Room Temperature Phosphorescence. ACS Sustain. Chem. Eng. 2018, 6, 1732-1743. [CrossRef]

151. Wang, B.; Zhuo, S.; Chen, L.; Zhang, Y. Fluorescent graphene quantum dot nanoprobes for the sensitive and selective detection of mercury ions. Spectrochim. Acta Part A Mol. Biomol. Spectrosc. 2014, 131, 384-387. [CrossRef]

152. Zhao, Q.; Rong, X.; Chen, L.; Ma, H.; Tao, G. Layer-by-layer self-assembly xylenol orange functionalized $\mathrm{CdSe} / \mathrm{CdS}$ quantum dots as a turn-on fluorescence lead ion sensor. Talanta 2013, 114, 110-116. [CrossRef]

153. Zhu, H.; Yu, T.; Xu, H.; Zhang, K.; Jiang, H.; Zhang, Z.; Wang, Z.; Wang, S. Fluorescent nanohybrid of gold nanoclusters and quantum dots for visual determination of lead ions. ACS Appl. Mater. Interfaces 2014, 6, 21461-21467. [CrossRef]

154. Qu, H.; Cao, L.; Su, G.; Liu, W.; Gao, R.; Xia, C.; Qin, J. Silica-coated ZnS quantum dots as fluorescent probes for the sensitive detection of $\mathrm{Pb}^{2+}$ ions. J. Nanoparticle Res. 2014, 16. [CrossRef]

155. Xu, J.; Jie, X.; Xie, F.; Yang, H.; Wei, W.; Xia, Z. Flavonoid moiety-incorporated carbon dots for ultrasensitive and highly selective fluorescence detection and removal of $\mathrm{Pb}^{2+}$. Nano Res. 2018, 11, 3648-3657. [CrossRef] 
156. Xu, S.; Xu, S.; Zhu, Y.; Xu, W.; Zhou, P.; Zhou, C.; Dong, B.; Song, H. A novel upconversion, fluorescence resonance energy transfer biosensor (FRET) for sensitive detection of lead ions in human serum. Nanoscale 2014, 6, 12573-12579. [CrossRef]

157. Wang, Q.; Yu, X.; Zhan, G.; Li, C. Fluorescent sensor for selective determination of copper ion based on $\mathrm{N}$-acetyl-1-cysteine capped CdHgSe quantum dots. Biosens. Bioelectron. 2014, 54, 311-316. [CrossRef]

158. Elmizadeh, H.; Soleimani, M.; Faridbod, F.; Bardajee, G.R. Ligand-Capped CdTe Quantum Dots as a Fluorescent Nanosensor for Detection of Copper Ions in Environmental Water Sample. J. Fluoresc. 2017, 27, 2323-2333. [CrossRef]

159. Liu, Y.; Tang, X.; Zhu, T.; Deng, M.; Ikechukwu, I.P.; Huang, W.; Yin, G.; Bai, Y.; Qu, D.; Huang, X.; et al. All-inorganic $\mathrm{CsPBr}_{3}$ perovskite quantum dots as a photoluminescent probe for ultrasensitive $\mathrm{Cu}^{2+}$ detection. J. Mater. Chem. C 2018, 6, 4793-4799. [CrossRef]

160. Qin, J.; Dong, B.; Gao, R.; Su, G.; Han, J.; Li, X.; Liu, W.; Wang, W.; Cao, L. Water-soluble silica-coated ZnS: Mn nanoparticles as fluorescent sensors for the detection of ultratrace copper(II) ions in seawater. Anal. Methods 2017, 9, 322-328. [CrossRef]

161. Xie, Z.; Sun, X.; Jiao, J.; Xin, X. Ionic liquid-functionalized carbon quantum dots as fluorescent probes for sensitive and selective detection of iron ion and ascorbic acid. Colloids Surfaces A Physicochem. Eng. Asp. 2017, 529, 38-44. [CrossRef]

162. Liu, Y.; Duan, W.; Song, W.; Liu, J.; Ren, C.; Wu, J.; Liu, D.; Chen, H. Red Emission B, N, S-co-Doped Carbon Dots for Colorimetric and Fluorescent Dual Mode Detection of $\mathrm{Fe}^{3+}$ Ions in Complex Biological Fluids and Living Cells. ACS Appl. Mater. Interfaces 2017, 9, 12663-12672. [CrossRef]

163. Satnami, M.L.; Vaishanav, S.K.; Nagwanshi, R.; Ghosh, K.K. Spectrofluorometric Determination of Mercury and Lead by Colloidal CdS Nanomaterial. J. Dispers. Sci. Technol. 2016, 37, 196-204. [CrossRef]

164. Elmizadeh, H.; Soleimani, M.; Faridbod, F.; Bardajee, G.R. A sensitive nano-sensor based on synthetic ligand-coated CdTe quantum dots for rapid detection of $\mathrm{Cr}(\mathrm{III})$ ions in water and wastewater samples. Colloid Polym. Sci. 2018, 296, 1581-1590. [CrossRef]

165. Wang, J.; Jiang, C.; Wang, X.; Wang, L.; Chen, A.; Hu, J.; Luo, Z. Fabrication of an "ion-imprinting" dual-emission quantum dot nanohybrid for selective fluorescence turn-on and ratiometric detection of cadmium ions. Analyst 2016, 141, 5886-5892. [CrossRef]

166. Liu, M.; Hu, M.; Jiang, Q.; Lu, Z.; Huang, Y.; Tan, Y.; Jiang, Q. A novel coumarin derivative as a sensitive probe for tracing intracellular $\mathrm{pH}$ changes. RSC Adv. 2015, 5, 15778-15783. [CrossRef]

167. Tan, J.-L.; Zhang, M.-X.; Zhang, F.; Yang, T.-T.; Liu, Y.; Li, Z.-B.; Zuo, H. A novel “off-on" colorimetric and fluorescent rhodamine-based $\mathrm{pH}$ chemosensor for extreme acidity. Spectrochim. Acta Part A Mol. Biomol. Spectrosc. 2015, 140, 489-494. [CrossRef]

168. Zheng, X.; Zhang, W.; Mu, L.; Zeng, X.; Xue, S.; Tao, Z.; Yamatob, T. A novel rhodamine-based thiacalix[4]arene fluorescent sensor for $\mathrm{Fe}^{3+}$ and $\mathrm{Cr}^{3+}$. J. Incl. Phenom. Macrocycl. Chem. 2010, 68, 139-146. [CrossRef]

169. Chen, H.; Huang, H.; Huang, X.; Clifford, J.N.; Forneli, A.; Palomares, E.; Zheng, X.; Zheng, L.; Wang, X.; Shen, P.; et al. High molar extinction coefficient branchlike organic dyes containing Di(p-tolyl)phenylamine donor for dye-sensitized solar cells applications. J. Phys. Chem. C 2010, 114, 3280-3286. [CrossRef]

170. Sun, W.-C.; Gee, K.R.; Klaubert, D.H.; Haugland, R.P. Synthesis of fluorinated fluoresceins. J. Org. Chem. 1997, 62, 6469-6475. [CrossRef]

171. Zheng, H.; Zhan, X.-Q.; Bian, Q.-N.; Zhang, X.-J. Advances in modifying fluorescein and rhodamine fluorophores as fluorescent chemosensors. Chem. Commun. 2013, 49, 429-447. [CrossRef]

172. Chang, P.V.; Bertozzi, C.R. Imaging beyond the proteome. Chem. Commun. 2012, 48, 8864-8879. [CrossRef]

173. Wanichacheva, N. Design and Synthesis of Ionophores and Fluoroionophores for the Detection of Lithium and Ammoniums Ions; Worcester Polytechnic Institute: Worcester, MA, USA, 2006.

174. Kaur, M.; Choi, D.H. Diketopyrrolopyrrole: Brilliant red pigment dye-based fluorescent probes and their applications. Chem. Soc. Rev. 2015, 44, 58-77. [CrossRef]

175. Valeur, B.; Leray, I. Design principles of fluorescent molecular sensors for cation recognition. Coord. Chem. Rev. 2000, 205, 3-40. [CrossRef]

176. Doludda, M.; Kastenholz, F.; Lewitzki, E.; Grell, E. Time-resolved response of fluorescent alkali ion indicators and detection of short-lived intermediates upon binding to molecular cavities. J. Fluoresc. 1996, 6, 159-163. [CrossRef] 
177. Nguyen, T.H.; Wren, S.P.; Sun, T.; Grattan, K.T.V. Development of a fiber-optic chemical sensor for the detection of cadmium. In Proceedings of the IEEE Sensors, Glasgow, Scotland, 29 October-1 November 2017.

178. Lee, H.Y.; Swamy, K.M.K.; Jung, J.Y.; Kim, G.; Yoon, J. Rhodamine hydrazone derivatives based selective fluorescent and colorimetric chemodosimeters for $\mathrm{Hg}^{2+}$ and selective colorimetric chemosensor for $\mathrm{Cu}^{2+}$. Sens. Actuators B Chem. 2013, 182, 530-537. [CrossRef]

179. Niu, Y.; Qian, Y. Synthesis and aggregation-induced emission enhancement of naphthalimide-rhodamine dye. J. Photochem. Photobiol. A Chem. 2016, 329, 88-95. [CrossRef]

180. Biswal, B.; Mallick, D.; Thirunavoukkarasu, M.; Mohanty, R.; Bag, B. A pyridine and pyrrole coupled rhodamine derivative for $\mathrm{Co}(\mathrm{II})$ ion detection and its imaging application in plant tissues. Sens. Actuators $B$ Chem. 2016, 232, 410-419. [CrossRef]

181. Chen, X.; Ma, H. A selective fluorescence-on reaction of spiro form fluorescein hydrazide with $\mathrm{Cu}(\mathrm{II})$. Anal. Chim. Acta 2006, 575, 217-222. [CrossRef]

182. Du, X.-L.; Zhang, H.-S.; Guo, X.-F.; Deng, Y.-H.; Wang, H. 6-Oxy-(acetyl piperazine) fluorescein as a new fluorescent labeling reagent for free fatty acids in serum using high-performance liquid chromatography. J. Chromatogr. A 2007, 1169, 77-85. [CrossRef]

183. Wu, W.-N.; Wu, H.; Wang, Y.; Mao, X.-J.; Zhao, X.-L.; Xu, Z.-Q.; Fan, Y.-C.; Xu, Z.-H. A highly sensitive and selective off-on fluorescent chemosensor for hydrazine based on coumarin $\beta$-diketone. Spectrochim. Acta Part A Mol. Biomol. Spectrosc. 2018, 188, 80-84. [CrossRef]

184. Karaoglu, K.; Yilmaz, F.; Menteşe, E. A New Fluorescent “Turn-Off” Coumarin-Based Chemosensor: Synthesis, Structure and Cu-Selective Fluorescent Sensing in Water Samples. J. Fluoresc. 2017, 27, 1293-1298. [CrossRef]

185. Li, M.; Sun, Y.; Dong, L.; Feng, Q.-C.; Xu, H.; Zang, S.-Q.; Mak, T.C.W. Colorimetric recognition of $\mathrm{Cu}^{2+}$ and fluorescent detection of $\mathrm{Hg}^{2+}$ in aqueous media by a dual chemosensor derived from rhodamine B dye with a $\mathrm{NS}_{2}$ receptor. Sens. Actuators B Chem. 2016, 226, 332-341. [CrossRef]

186. Haugland, R.P. The Handbook: A Guide to Fluorescent Probes and Labeling Technologies, 10th ed.; Invitrogen Corp.: Carlsbad, CA, USA, 2005.

187. Ruan, S.; Ebendorff-Heidepriem, H.; Ruan, Y. Optical fibre turn-on sensor for the detection of mercury based on immobilized fluorophore. Measurement 2018, 121, 122-126. [CrossRef]

188. Li, M.; Jiang, X.-J.; Wu, H.-H.; Lu, H.-L.; Li, H.-Y.; Xu, H.; Zang, S.-Q.; Mak, T.C.W. A dual functional probe for "turn-on" fluorescence response of $\mathrm{Pb}^{2+}$ and colorimetric detection of $\mathrm{Cu}^{2+}$ based on a rhodamine derivative in aqueous media. Dalton Trans. 2015, 44, 17326-17334. [CrossRef]

189. Su, W.; Yuan, S.; Wang, E. A Rhodamine-Based Fluorescent Chemosensor for the Detection of $\mathrm{Pb}^{2+}, \mathrm{Hg}^{2+}$ and $\mathrm{Cd}^{2+}$. J. Fluoresc. 2017, 27, 1871-1875. [CrossRef] [PubMed]

190. Wan, J.; Zhang, K.; Li, C.; Li, Y.; Niu, S. A novel fluorescent chemosensor based on a rhodamine $6 \mathrm{G}$ derivative for the detection of $\mathrm{Pb}^{2+}$ ion. Sens. Actuators B Chem. 2017, 246, 696-702. [CrossRef]

191. Liu, C.; Huang, S.; Yao, H.; He, S.; Lu, Y.; Zhao, L.; Zeng, X. Preparation of fluorescein-based chemosensors and their sensing behaviors toward silver ions. RSC Adv. 2014, 4, 16109-16114. [CrossRef]

192. Wu, G.; Li, M.; Zhu, J.; Lai, K.W.C.; Tong, Q.; Lu, F. A highly sensitive and selective turn-on fluorescent probe for $\mathrm{Pb}$ (II) ions based on a coumarin-quinoline platform. RSC Adv. 2016, 6, 100696-100699. [CrossRef]

193. Jiao, Y.; Zhang, L.; Zhou, P. A rhodamine B-based fluorescent sensor toward highly selective mercury (II) ions detection. Talanta 2016, 150, 14-19. [CrossRef] [PubMed]

194. Li, L.; Fang, Z. A novel "turn on" glucose-based rhodamine B fluorescent chemosensor for mercury ions recognition in aqueous solution. Spectrosc. Lett. 2015, 48, 578-585. [CrossRef]

195. Gao, T.; Lee, K.M.; Kim, S.H.; Heo, J.; Yang, S.I. A Mercuric Ion Selective Fluorescent Sensor Based on Rhodamine B with an Ethylene Unit. Bull. Korean Chem. Soc. 2017, 38, 292-295. [CrossRef]

196. Long, Y.; Yang, M.-P.; Yang, B.-Q. Development and applications of two colorimetric and fluorescent indicators for $\mathrm{Hg}^{2+}$ detection. J. Inorg. Biochem. 2017, 172, 23-33. [CrossRef] [PubMed]

197. Li, X.-M.; Zhao, R.-R.; Wei, Y.-L.; Yang, D.; Zhou, Z.-J.; Zhang, J.-F.; Zhou, Y. A rhodamine derivative for $\mathrm{Hg}^{2+}$-selective colorimetric and fluorescent sensing and its application to in vivo imaging. Chin. Chem. Lett. 2016, 27, 813-816. [CrossRef]

198. Yan, F.; Cao, D.; Wang, M.; Yang, N.; Yu, Q.; Dai, L.; Chen, L. A new rhodamine-based "off-on" fluorescent chemosensor for $\mathrm{Hg}$ (II) ion and its application in imaging $\mathrm{Hg}$ (II) in living cells. J. Fluoresc. 2012, 22, 1249-1256. [CrossRef] 
199. Yan, F.; Wang, M.; Cao, D.; Yang, N.; Fu, Y.; Chen, L.; Chen, L. New fluorescent and colorimetric chemosensors based on the rhodamine detection of $\mathrm{Hg}^{2+}$ and $\mathrm{Al}^{3+}$ and application of imaging in living cells. Dye Pigment. 2013, 98, 42-50. [CrossRef]

200. Bera, K.; Das, A.K.; Nag, M.; Basak, S. Development of a rhodamine-rhodanine-based fluorescent mercury sensor and its use to monitor real-time uptake and distribution of inorganic mercury in live zebrafish larvae. Anal. Chem. 2014, 86, 2740-2746. [CrossRef] [PubMed]

201. Wanichacheva, N.; Hanmeng, O.; Kraithong, S.; Sukrat, K. Dual optical $\mathrm{Hg}^{2+}$-selective sensing through FRET system of fluorescein and rhodamine B fluorophores. J. Photochem. Photobiol. A Chem. 2014, 278, 75-81. [CrossRef]

202. Nguyen, T.H.; Wren, S.P.; Sun, T.; Grattan, K.T.V. Fluorescent optical fibre chemosensor for the detection of mercury. In Proceedings of the SPIE-The International Society for Optical Engineering, Baltimore, MD, USA, 18-19 April 2016; Volume 10013.

203. Huang, K.; Jiao, X.; Liu, C.; Wang, Q.; Qiu, X.; Zheng, D.; He, S.; Zhao, L.; Zeng, X. Highly selective and sensitive fluorescent probe for mercury ions based on a novel rhodol-coumarin hybrid dye. Dye Pigment. 2017, 142, 437-446. [CrossRef]

204. Xu, Y.; Jiang, Z.; Xiao, Y.; Zhang, T.-T.; Miao, J.-Y.; Zhao, B.-X. A new fluorescent turn-on chemodosimeter for mercury ions in solution and its application in cells and organisms. Anal. Chim. Acta 2014, 807, 126-134. [CrossRef] [PubMed]

205. Ncube, P.; Krause, R.W.M.; Ndinteh, D.T.; Mamba, B.B. Fluorescent sensing and determination of mercury (II) ions in water. Water SA 2014, 40, 175-182. [CrossRef]

206. Han, Y.; Yang, C.; Wu, K.; Chen, Y.; Zhou, B.; Xia, M. A facile naphthalene-based fluorescent chemodosimeter for mercury ions in aqueous solution. RSC Adv. 2015, 5, 16723-16726. [CrossRef]

207. Aliberti, A.; Vaiano, P.; Caporale, A.; Consales, M.; Ruvo, M.; Cusano, A. Fluorescent chemosensors for $\mathrm{Hg}^{2+}$ detection in aqueous environment. Sens. Actuators B Chem. 2017, 247, 727-735. [CrossRef]

208. Sunnapu, O.; Kotla, N.G.; Maddiboyina, B.; Singaravadivel, S.; Sivaraman, G. A rhodamine based "turn-on" fluorescent probe for $\mathrm{Pb}(\mathrm{II})$ and live cell imaging. RSC Adv. 2015, 6, 656-660. [CrossRef]

209. Shaily; Kumar, A.; Parveen, I.; Ahmed, N. Highly selective and sensitive coumarin-triazole-based fluorometric 'turn-off' sensor for detection of $\mathrm{Pb}^{2+}$ ions. Luminescence 2018, 33, 713-721. [CrossRef]

210. Liu, J.; Wu, K.; Li, S.; Song, T.; Han, Y.; Li, X. A highly sensitive and selective fluorescent chemosensor for $\mathrm{Pb}^{2+}$ ions in an aqueous solution. Dalton Trans. 2013, 42, 3854-3859. [CrossRef] [PubMed]

211. Karak, D.; Banerjee, A.; Lohar, S.; Sahana, A.; Mukhopadhyay, S.K.; Adhikari, S.S.; Das, D. Xanthone based $\mathrm{Pb}^{2+}$ selective turn on fluorescent probe for living cell staining. Anal. Methods 2013, 5, 169-172. [CrossRef]

212. Sinha, S.; Rani Koner, R.; Kumar, S.; Mathew, J.; Roy, A.; Kanti Mukhopadhyay, S.; Nandi, C.K.; Ghosh, S. Structurally tuned benzo[h]chromene derivative as $\mathrm{Pb}^{2+}$ selective "turn-on" fluorescence sensor for living cell imaging. J. Lumin. 2013, 143, 355-360. [CrossRef]

213. Saleem, M.; Lee, K.-H. Selective fluorescence detection of $\mathrm{Cu} 2+$ in aqueous solution and living cells. J. Lumin. 2014, 145, 843-848. [CrossRef]

214. Karuk Elmas, Ş.N.; Ozen, F.; Koran, K.; Yilmaz, I.; Gorgulu, A.O.; Erdemir, S. Coumarin Based Highly Selective "off-on-off" Type Novel Fluorescent Sensor for $\mathrm{Cu}^{2+}$ and $\mathrm{S}^{2-}$ in Aqueous Solution. J. Fluoresc. 2017, 27, 463-471. [CrossRef] [PubMed]

215. Bao, X.; Cao, Q.; Wu, X.; Shu, H.; Zhou, B.; Geng, Y.; Zhu, J. Design and synthesis of a new selective fluorescent chemical sensor for $\mathrm{Cu}^{2+}$ based on a Pyrrole moiety and a Fluorescein conjugate. Tetrahedron Lett. 2016, 57, 942-948. [CrossRef]

216. Yang, X.; Zeng, W.; Wang, L.; Lu, X.; Yan, Y.; Qu, J.; Liu, R. A new fluorescent probe based on styrylcyanine dye containing pyridine: Dissimilar fluorescent response to $\mathrm{Cu}^{2+}$ and $\mathrm{Pb}^{2+}$. RSC Adv. 2014, 4, 22613-22616. [CrossRef]

217. An, J.-M.; Yan, M.-H.; Yang, Z.-Y.; Li, T.-R.; Zhou, Q.-X. A turn-on fluorescent sensor for Zn(II) based on fluorescein-coumarin conjugate. Dye Pigment 2013, 99, 1-5. [CrossRef]

218. Ashwin, B.C.M.A.; Sivaraman, G.; Stalin, T.; Yuvakkumar, R.; Muthu Mareeswaran, P. Selective and sensitive fluorescent sensor for $\mathrm{Pd}^{2+}$ using coumarin 460 for real-time and biological applications. J. Photochem. Photobiol. B Biol. 2018, 183, 302-308. [CrossRef] 
219. Wu, D.; Huang, Y.; Hu, S.; Yi, X.; Wang, J. Sensitive $\mathrm{Hg}^{2+}$ Sensing via Quenching the Fluorescence of the Complex between Polythymine and 5,10,15,20-tetrakis( $N$-methyl-4-pyridyl) Porphyrin (TMPyP). Sensors (Basel) 2018, 18, 3998. [CrossRef]

220. Huang, W.-B.; Gu, W.; Huang, H.-X.; Wang, J.-B.; Shen, W.-X.; Lv, Y.-Y.; Shen, J. A porphyrin-based fluorescent probe for optical detection of toxic $\mathrm{Cd}^{2+}$ ion in aqueous solution and living cells. Dye Pigment 2017, 143, 427-435. [CrossRef]

221. Zhang, X.; Xia, T.; Jiang, K.; Cui, Y.; Yang, Y.; Qian, G. Highly sensitive and selective detection of mercury (II) based on a zirconium metal-organic framework in aqueous media. J. Solid State Chem. 2017, 253, 277-281. [CrossRef]

222. Yang, C.-X.; Ren, H.-B.; Yan, X.-P. Fluorescent metal-organic framework MIL-53(Al) for highly selective and sensitive detection of $\mathrm{Fe}^{3+}$ in aqueous solution. Anal. Chem. 2013, 85, 7441-7446. [CrossRef] [PubMed]

223. Wang, J.; Xia, T.; Zhang, X.; Zhang, Q.; Cui, Y.; Yang, Y.; Qian, G. A turn-on fluorescent probe for Cd ${ }^{2+}$ detection in aqueous environments based on an imine functionalized nanoscale metal-organic framework. RSC Adv. 2017, 7, 54892-54897. [CrossRef]

(C) 2019 by the authors. Licensee MDPI, Basel, Switzerland. This article is an open access article distributed under the terms and conditions of the Creative Commons Attribution (CC BY) license (http://creativecommons.org/licenses/by/4.0/). 